\title{
CAMILLA FANELLI
}

\section{Efeito da associação de losartan e hidroclorotiazida em modelo experimental de nefropatia crônica resultante da administração de losartan durante a lactação ( $\left.L_{\text {Lact }}\right)$}

Tese apresentada à Faculdade de Medicina da Universidade de São Paulo para obtenção do título de Doutor em Ciências

Programa de Nefrologia

Orientador: Prof. Dr. Roberto Zatz

São Paulo 
Dados Internacionais de Catalogação na Publicação (CIP)

Preparada pela Biblioteca da

Faculdade de Medicina da Universidade de São Paulo

Creprodução autorizada pelo autor

Fanelli, Camilla

Efeito da associação de losartan e hidroclorotiazida em modelo experimental de nefropatia crônica resultante da administração de losartan durante a lactação $\left(\mathrm{L}_{\mathrm{Lact}}\right)$ / Camilla Fanelli. -- São Paulo, 2011.

Tese(doutorado)--Faculdade de Medicina da Universidade de São Paulo. Programa de Nefrologia.

Orientador: Roberto Zatz.

Descritores: 1.Falência renal crônica 2.Sistema renina-angiotensina 3.Tiazidas 4.Ratos Wistar

USP/FM/DBD-079/11 


\section{DEDICATÓRIA}

Dedico este trabalho aos Fanelli. Tanto àqueles que estão presentes em meu dia-a-dia quanto àqueles que estão presentes em minha memória. Povo guerreiro que me ensinou a batalhar para atingir cada um dos meus objetivos. Muito obrigada por permitir que eu também fosse uma Fanelli.

"A medicina é como a lenta construção de uma parede. Temos sorte se, durante uma vida inteira, conseguimos colocar um tijolo. Se pudermos explicar a doença, alguém que ainda não nasceu pode descobrir a cura."

Retirado do livro "O Físico" de autoria de Noah Gordon 


\section{AGRADECIMENTOS}

Agradeço à Faculdade de Medicina da Universidade de São Paulo (FMUSP), que me acolheu como estagiária e aprendiz para minha iniciação científica, nos idos de 2002 e que até hoje tem sido minha segunda morada e minha constante fonte de sabedoria e realizações.

A meu orientador, Prof. Dr. Roberto Zatz pela oportunidade de realizar minha pós-graduação em seu laboratório e sob a sua tutoria. Agradeço também pela paciência e pela sincera amizade.

À Dra. Clarice Kazue Fujihara, minha co-orientadora e grande amiga. Obrigada pelas dicas, pelos conselhos, pelas longas discussões sobre os rumos deste trabalho, pelas cirurgias dos animais, enfim, por tudo. Muito Obrigada!

À Dra. Denise Maria Avancini da Costa Malheiros, patologista responsável pela interpretação dos resultados de toda a análise histologica deste estudo.

Agradeço à Dra. Irene de Lourdes Noronha, Dr. Luiz Fernando Onuchic, Dra. Terezila Machado Coimbra, Dra. Viktoria Woronik, Dr. Joel Claudio Heimann, Dra. Vanda Jorgetti, Dra. Claudia de Barros Helou e Dr. Antônio Carlos Seguro, que de maneira direta e indireta auxiliaram na 
realização desse estudo. Obrigada pela o uso de equipamentos, pelas dicas e sugestões valiosas e pela participação em minha banca de qualificação.

À comissão de pós-graduação do Serviço de Nefrologia do Departamento de Clínica Médica da FMUSP pela oportunidade e por todos os auxílios para a participação em Congressos e Eventos.

Aos colegas Flavia Gomes Machado, Cristiene Okabe, Simone Ribeiro da Costa, Cláudia Ramos de Sena, Bianca Helena Ventura Fernandes, Wagner Vasques Dominguez, Luciana Faria de Carvalho, Flavio Teles de Farias Filho, Janice da Graça Silva Pião, e a todos os demais que me auxiliaram no trato com os animais, nos experimentos e dosagens, nas discussões dos resultados e que, de certa forma, também são responsáveis pela conclusão de mais essa etapa de minha vida. Muito Obrigada! 


\section{SUMÁRIO}

RESUMO

ABSTRACT

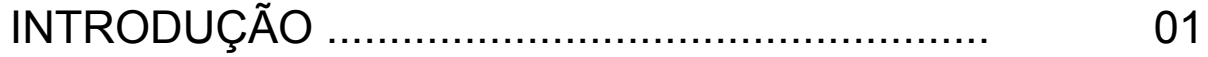

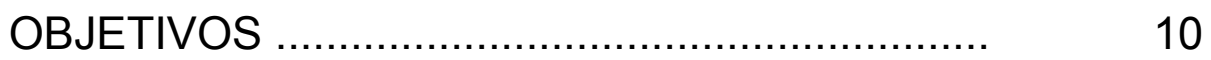

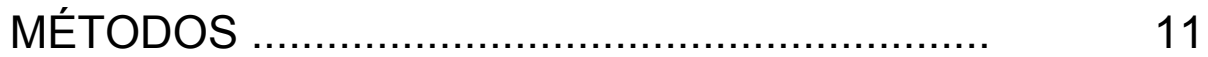

Modelo Experimental ................................ 11

Grupos ............................................. 12

Protocolo .................................................. 13

Análises Bioquímicas ............................... 13

Histologia e Imuno-histoquímica .................... 16

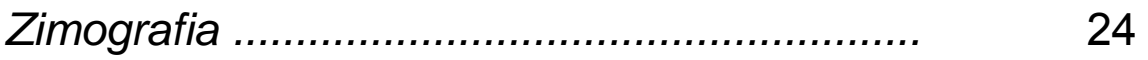

Análises Estatísticas .................................. 25

RESULTADOS ...................................... 27

Parâmetros Gerais ..................................... 27

Análise Histológica e Imuno-histoquímica ....... 36

Zimografia ........................................ 56

DISCUSSÃO …....................................... 59

CONCLUSÕES ........................................ 75

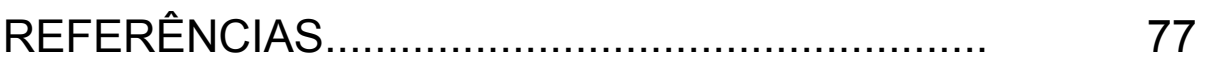




\section{RESUMO}

Fanelli C. Efeitos da associação de losartan (L) e hidroclorotiazida (H) em modelo experimental de doença renal crônica (DRC), resultante da administração de $L$ durante a lactação ( $L_{\text {Lact }}$ [tese]. São Paulo: Faculdade de Medicina, Universidade de São Paulo; 2011

Descrevemos recentemente um novo modelo de DRC, baseado nos efeitos adversos da administração de $L$ na lactação ( $L_{\text {Lact }}$ ). Os objetivos do presente estudo foram; caracterizar os mecanismos patológicos envolvidos com a nefropatia do $L_{\text {Lact }} \mathrm{e}$ investigar se o extraordinário efeito renoprotetor obtido com a associação $L+H$ no modelo $N X$ seria reproduzido no modelo $L_{\text {Lact. }}$ Utilizamos 20 ratas Munich-Wistar lactantes, com 6 filhotes cada. As matrizes receberam $L, 250 \mathrm{mg} / \mathrm{Kg} / \mathrm{d}$ durante a amamentação e a droga atingiu a prole via leite materno. Os filhotes machos foram acompanhados até os 7 meses de vida, quando se verificou; pressão caudal, albuminúria, creatinina sérica, glomerulosclerose, expansão intersticial, proliferação celular, presença de miofibroblastos intersticiais e rarefação capilar. Os animais $L_{\text {Lact }}$ restantes foram divididos em 3 novos grupos: $L_{\text {Lact }}+V$, mantido sem tratamento, $L_{\text {Lact }}+\mathrm{L}, \mathrm{L}_{\mathrm{Lact}}+\mathrm{H}$, e $\mathrm{L}_{\mathrm{Lact}}+\mathrm{LH}$. Os parâmetros foram reavaliados após 3 meses nesses grupos e também em animais controle (C). Os ratos, LLact apresentaram hipertensão, albuminuria, glomerulosclerose (GS) e lesão intersticial com inflamação e fibrose aos 10 meses de vida. O tratamento com L+H na vida adulta limitou a hipertensão, albuminúria, GS, proliferação intersticial e infiltração de miofibroblastos. Porém, a renoproteção obtida pela associação foi moderada em relação aos resultados previamente obtidos com o modelo $\mathrm{NX}$, especialmente no tocante ao comprometimento tubulointersticial.

Descritores: 1.Falência renal crônica 2.Sistema renina-angiotensina 3.Tiazidas 4.Ratos Wistar 


\section{SUMMARY}

Fanelli C. Combined losartan (L) and hydrochlorothiazide (H) prevent progression of renal damage in chronic kidney disease (CKD) resulting from $L$ treatment during lactation ( $\left.L_{\text {Lact }}\right)$ [thesis]. São Paulo: "Faculdade de Medicina, Universidade de São Paulo"; 2011

We recently standardized a severe CKD model based on impaired nephrogenesis by suppression of angiotensin II (Ang II) activity during lactation $\left(L_{\text {Lact }}\right)$. In the present study we sought to gain further insight into the mechanisms associated with the $L_{\text {Lact }}$ model and to verify if the renoprotection obtained with the association of the Ang II receptor blocker, Losartan (L), and Hydrochlorothiazide $(\mathrm{H})$, which arrested renal injury in the remnant kidney model, could be also obtained in the LLact model. Twenty Munich-Wistar dams, each nursing 6 pups, received L, $250 \mathrm{mg} / \mathrm{kg} / \mathrm{d}$, until weaning. The male $L_{\text {Lact }}$ offspring remained untreated until 7 months of age, when renal functional and structural parameters were studied in 17 of them, used as pretreatment control ( $\left.L_{\text {Lact }} P r e\right)$, followed no further. The remaining rats were divided in groups: $\mathbf{L}_{\text {Lact }}+\mathbf{V}$, untreated, $\mathbf{L}_{\text {Lact }}+\mathbf{L}$, given $\mathbf{L}, 50 \mathrm{mg} / \mathrm{kg} /$ day, now as

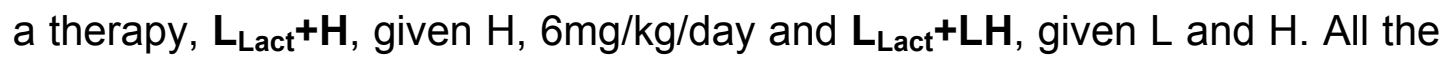
parameters were reassessed 3 months later in these groups and in agematched controls (C). At this time, $L_{\text {Lact }}$ rats exhibited hypertension, albuminuria, glomerulosclerosis (GS), interstitial expansion and inflammation, enhanced cell proliferation, myofibroblast infiltration, and creatinine retention. LH therapy normalized blood pressure, albuminuria, GS, and limited interstitial cell proliferation and $\alpha$-smooth muscle actin ( $\alpha$-SMA) accumulation. However, LH renoprotection achieved with the $L_{\text {Lact }}$ model was only mild if compared previous studies with the 5/6 renal ablation model.

Descriptors: 1.Chronic kidney disease 2.Renin-angiotensin system 3. Thiazides 


\section{INTRODUÇÃO}

A insuficiência renal crônica terminal (IRCT) representa um importante problema de saúde pública. Anualmente, cerca de 100 novos casos de IRCT são diagnosticados para cada milhão de habitantes em todo o mundo; no Brasil, cerca de 20.000 novos pacientes são matriculados nos programas de diálise crônica anualmente, e este índice cresce a cerca de $8 \%$ ao ano [1,2].

De acordo com o censo da diálise do "Data/SUS" da Sociedade Brasileira de Nefrologia (SBN), em 2009, o total de pacientes em diálise crônica ultrapassava os 77.000 , enquanto a população de pacientes que viviam com um rim transplantado superava os 20.000 . Como para cada paciente em diálise calcula-se existirem por volta de 25 portadores de doença renal crônica (DRC), é provável que o número de brasileiros acometidos por esse mal se aproxime de 2.000.000. Essa alta prevalência de DRC motiva a comunidade médica e científica a desenvolver estudos a fim de compreender melhor a sua patogênese e buscar novas alternativas de tratamento $[1,2]$.

O processo que leva à perda progressiva da função renal pode iniciarse por uma agressão de origem imunológica ou não-imunológica (presumivelmente hemodinâmica), embora a tênue fronteira entre essas duas causas por vezes não possa ser facilmente identificada. Com a perda de néfrons decorrente do processo inicial, ocorrem alterações hemodinâmicas nos néfrons remanescentes, caracterizadas pela diminuição da resistência arteriolar, aumento do fluxo plasmático e elevação da pressão 
hidráulica nos capilares glomerulares, resultando em hiperfiltração compensatória. Essas anomalias em geral são acompanhadas por alterações estruturais como hipertrofia glomerular, expansão de matriz mesangial e lesão epitelial com perda de podócitos. O resultado desse processo é o desenvolvimento de glomerulosclerose (GS), culminando com a perda de função do glomérulo [5-7]. Dessa maneira, desencadeia-se um processo de retro-alimentação que leva à progressão da patologia à medida que a perda gradual de glomérulos sobrecarrega os néfrons remanescentes, levando por sua vez à perda de mais unidades.

Além do conhecido papel da lesão glomerular, a atrofia tubular e a fibrose intersticial têm um papel destacado no processo de perda da função renal $[5,6]$.

Os mecanismos envolvidos na patogênese das lesões glomerulares e intersticiais no processo de progressão da DRC não se limitam apenas a alterações hemodinâmicas decorrentes da perda de massa renal. É cada vez mais evidente a participação de mecanismos celulares e inflamatórios nesse processo. A ativação das células renais, provocada pela agressão inicial, induz o influxo de células inflamatórias para o interstício renal, as quais produzem uma variedade de mediadores que instalam uma atividade proliferativa e inflamatória no tecido. Este fenômeno torna-se autônomo, contribuindo de forma persistente para a progressão da DRC [5-7].

Dentre os fatores que estimulam a progressão da DRC, a ativação do sistema renina-angiotensina-aldosterona (SRAA) merece destaque. Sabe-se que a angiotensina II (All), um dos componentes efetores do SRAA, é um 
dos principais mediadores envolvidos na progressão da DRC. A All tem sua ação biológica mediada por receptores específicos de membrana, especialmente o AT1, embora haja evidências da participação de outros receptores, principalmente o AT2.

Além dos efeitos biológicos já bem estabelecidos, tais como vasoconstrição e promoção de retenção de sódio e água, (que levam à hipertensão sistêmica e glomerular), a ativação do SRAA tem sido também relacionada ao processo inflamatório e fibrogênico que acompanha o desenvolvimento da nefropatia crônica. Há evidências de que a All seja capaz de estimular a infiltração de células inflamatórias, tais como leucócitos e macrófagos, bem como a proliferação celular, levando ao desenvolvimento ou à piora do quadro inflamatório e ao acúmulo de matriz intersticial, ocasionando o desenvolvimento de fibrose [8-10].

Em contraste com os efeitos patogênicos da All no desenvolvimento da $\mathrm{DRC}$, durante o processo da nefrogênese é extremamente necessária a integridade do SRAA para que ocorra um desenvolvimento renal normal, uma vez que essa molécula exerce importante efeito fisiológico na formação do sistema excretor [13]. Por se tratar de uma fase de intenso remodelamento tecidual, o processo da nefrogênese é caracterizado por proliferação celular ativa, acompanhada de apoptose em larga escala com objetivo de eliminar células indesejáveis $[15,16]$. Além de seu importante papel na regulação da pressão arterial (PA), a All é também conhecida como um fator promotor do desenvolvimento. Além de estimular o crescimento celular diretamente, a All pode regular a síntese de outros fatores de 
crescimento, bem como diversos mediadores químicos importantes para o desenvolvimento renal normal, atuando também como agente promotor da formação e ramificação da vasculatura do sistema excretor [13-16].

O bloqueio farmacológico dos receptores AT1 durante o período de desenvolvimento renal impede a ação fisiológica da All e, conseqüentemente, a correta formação das estruturas do sistema renal [1720]. Devido a esse possível efeito teratogênico, a administração de bloqueadores dos receptores AT1 e AT2 (BATR) é desaconselhável às gestantes e também às lactantes, pois se sabe que cerca de 20 a $50 \%$ da dose de BATR administrada chega ao leite materno [23-25].

Diferentemente do que ocorre com os seres humanos, nos quais os rins completam o seu desenvolvimento ainda durante o período gestacional, nos ratos a nefrogênese, bem como a maturação glomerular, conclui-se somente na segunda semana após o nascimento. Os componentes do SRAA são sintetizados localmente e sua detecção torna-se possível a partir do $12^{\circ}$ ao $17^{\circ}$ dia de gestação dos roedores. Tais componentes mostram-se mais abundantes nos tecidos fetais e de recém-nascidos do que nos adultos $[13,15]$

Diversos estudos demonstraram que em ratos a inibição do SRAA durante essa etapa final da nefrogênese acarreta alterações estruturais irreversíveis, que se refletem em grave limitação da função renal na fase adulta. O uso de inibidores da enzima conversora da angiotensina (iECA) durante essa fase resulta em anormalidades renais caracterizadas por atrofia papilar, espessamento anormal da parede das arteríolas intra-renais, 
atrofia tubular associada a expansão do interstício, diminuição do número de néfrons e uma redução marcante na capacidade de concentração urinária [14-17]. Efeitos semelhantes são observados quando o SRAA é suprimido farmacologicamente através da administração de uma droga antagonista do receptor AT1 para a All (BRAT1), sugerindo uma importância específica desse receptor. Guron et al. e Wood et al. sugerem que o BRAT1 interrompe o processo de maturação renal, reduzindo em cerca de $24 \%$ o número de glomérulos nesses animais. Como conseqüência dessas alterações estruturais renais, ocorre queda do ritmo de filtração glomerular global (RFG), do fluxo plasmático renal, bem como aumento da resistência vascular renal. O desenvolvimento tardio de hipertensão arterial na vida adulta também foi observado nesse e em outros estudos [13,18-20].

O emprego de modelos experimentais tem permitido uma melhor compreensão dos mecanismos envolvidos na progressão das doenças renais, possibilitando dessa forma a investigação de estratégias terapêuticas que interfiram nessa progressão. Um dos modelos mais utilizados na investigação da progressão DRC é a ablação renal de 5/6 (NX), na qual o rato é submetido à retirada do rim direito e tem $2 / 3$ de seu rim esquerdo enfartado através da ligadura de 2 ramos da artéria renal. A lesão produzida nesse modelo se caracteriza por desenvolvimento precoce de proteinúria maciça, hipertensão sistêmica e glomerular e infiltração de células inflamatórias. A persistência dessas características leva à progressão da nefropatia, com fibrose extensa e perda da função renal. 
Apesar de sua ampla utilização, o modelo NX apresenta algumas desvantagens. Por ser um modelo extremamente agressivo, o animal desenvolve abruptamente uma grave hipertensão e alcança a fase terminal da DRC muito rapidamente. Além disso, os índices de mortalidade nos animais submetidos à ablação de 5/6 são relativamente elevados.

Estudos recentes em nosso laboratório indicaram a possibilidade da utilização de animais submetidos à inibição do SRAA durante a lactação como um novo modelo de progressão da doença renal. Esse novo modelo baseia-se na administração oral de Losartan potássico (L), um BRAT-1, a ratos neonatos, através do leite materno [26, 27].

A principal vantagem da administração neonatal de bloqueadores do receptor AT1 como modelo experimental de DRC em relação ao modelo NX é a maior similaridade com as nefropatias humanas, que assim como nesse modelo, ocorrem na presença de dois rins. Além disso, a administração de $L$ a ratos neonatos pode ser considerada uma manobra bastante prática e exeqüível para a obtenção de um modelo experimental, uma vez que não requer manipulação genética ou procedimento cirúrgico. Outro ponto vantajoso desse novo modelo experimental é o baixo índice de mortalidade dos animais e o ritmo de desenvolvimento da $\mathrm{DRC}$, semelhante àquele observado em humanos.

Dentre as estratégias terapêuticas atualmente empregadas no controle da progressão da DRC destacam-se as drogas inibidoras do SRAA já que, conhecendo-se o importante papel da All na evolução da doença renal, é esperada a obtenção de um efeito benéfico com a redução da 
atividade biológica dessa molécula. O SRAA pode ter seus efeitos farmacologicamente suprimidos através de diversas estratégias; dentre as quais se destacam a inibição da atividade da enzima conversora da angiotensina I (ECA) e o bloqueio dos receptores AT1 da All, que permitem que esta molécula conecte-se às células e dê início à sua cascata de ações biológicas [29-35]. Estudos apontam para a obtenção de um importante efeito renoprotetor tanto com a utilização de drogas inibidoras da enzima conversora da angiotensina (IECA) quanto com BRAT1 [29-39].

Estudos realizados em nosso laboratório e em vários outros centros de pesquisa demonstraram que o tratamento do modelo $N X$ com $L$ leva à redução da pressão arterial (PA), à diminuição da pressão intraglomerular; bem como à redução da albuminúria e da GS, devido à inibição tanto do efeito hemodinâmico da All quanto da ativação da cascata inflamatória desencadeada por esta última [9]. Outros trabalhos descreveram a dosedependência desse tratamento, sugerindo que resultados ainda mais favoráveis podem ser obtidos com doses de $L$ superiores àquelas comumente administradas [37].

Portanto, em um aparente paradoxo, o tratamento com iECA/BAT1R é capaz de retardar a progressão das lesões nas diferentes nefropatias em indivíduos adultos, porém promove lesões renais irreversíveis quando administrados a ratos neonatos, que ainda não completaram sua nefrogênese.

Além do emprego de inibidores do SRAA, a administração de fármacos com o objetivo de controlar a PA também faz parte do arsenal 
contra a progressão da DRC [32-44]. Os diuréticos ocupam um lugar de destaque entre as drogas empregadas no controle da PA, pois é bem conhecida a relação direta entre a redução da capacidade excretora de sódio renal e o desenvolvimento de hipertensão: Com a finalidade de manter o volume extracelular em níveis normais, o organismo lança mão de um aumento da PA que, como conseqüência, restaura a natriurese (natriurese pressórica) e, por sua vez, o volume plasmático. Nesse contexto, os diuréticos restauram a capacidade de excreção renal de sódio, prevenindo ou limitando o desenvolvimento de hipertensão arterial [5]. Uma vez que esta contribui para a perpetuação do dano glomerular, os diuréticos potencializam o efeito renoprotetor dos inibidores do SRAA.

Os tiazídicos são considerados diuréticos de média potência, já que o túbulo convoluto distal, segmento do néfron onde essas drogas atuam, é responsável pela reabsorção de apenas 4 a $5 \%$ da carga filtrada de sódio. A ação dos diuréticos tiazídicos, como a Hidroclorotiazida $(\mathrm{H})$, consiste em inibir a atividade dos co-transportadores neutros que promovem a reabsorção de um íon sódio $\left(\mathrm{Na}^{+}\right)$e um íon cloreto $\left(\mathrm{Cl}^{-}\right)$através da membrana apical das células epiteliais do túbulo distal.

Um estudo clínico multicêntrico concluiu que o tratamento de nefropatias crônicas com $\mathrm{H}$ diminui riscos cardiovasculares tanto quanto os tratamentos à base de IECA [45]. Estudos mais recentes associaram a administração de tiazídicos com BRAT1 ou com IECA, obtendo renoproteção eficaz e significativa redução da proteinúria [42-44]. 
Com o objetivo de verificar o efeito da combinação de $\mathrm{L}$ com $\mathrm{H}$ no tratamento tardio da nefropatia associada ao NX, concluímos recentemente um projeto de pesquisa no qual administramos $\mathrm{L}$ e $\mathrm{H}$ em doses convencionais (50 mg/kg e $6 \mathrm{mg} / \mathrm{kg}$, respectivamente) a ratos submetidos a ablação renal de 5/6, por um período de 7 meses de tratamento. Os resultados relativos à albuminúria e à pressão caudal chegam a ser surpreendentes: a associação $\mathrm{L}$ e $\mathrm{H}$ normalizou os dois parâmetros, mantendo-os baixos por um inédito período de 7 meses de tratamento. Além disso, ao fim do estudo, a lesão renal estrutural havia sido mantida em níveis irrisórios [46].

Levando em consideração esses dados, decidimos aplicar esse mesmo tratamento duplo $(L+H)$, tão eficaz no modelo $N X$, no recémcaracterizado modelo de nefropatia crônica baseado na administração de L durante a lactação. Nossa expectativa era de que esta dupla terapia se mostrasse tão eficaz nesse novo modelo quanto se havia mostrado no modelo NX, uma vez que a patogênese da lesão renal provocada nesses dois modelos experimentais apresenta vários pontos em comum. 


\section{OBJETIVOS}

O presente estudo teve como principais objetivos:

1. Caracterizar alguns dos mecanismos fisiopatológicos envolvidos com a progressão da nefropatia causada pelo bloqueio do SRAA durante a nefrogênese.

2. Verificar se o importante efeito renoprotetor observado com o emprego da associação terapêutica de $\mathrm{L}$ e $\mathrm{H}$ no modelo de ablação renal de 5/6 pode ser reproduzido no recém-descrito modelo de nefropatia crônica progressiva, baseado na administração de $L$ durante a lactação. 


\section{MÉTODOS}

Neste estudo utilizamos ratos da cepa Munich-Wistar obtidos de uma colônia estabelecida no biotério do Laboratório de Fisiopatologia Renal da Faculdade de Medicina da Universidade de São Paulo. Os animais foram mantidos em temperatura ambiente de $23 \pm 1^{\circ} \mathrm{C}$, umidade relativa de $60 \pm 5 \%$ e ciclo claro/escuro de 12/12h. Todos os animais utilizados neste estudo tiveram livre acesso a uma ração convencional para roedores (Nuvital, Curitiba, PR) e água.

\section{Modelo Experimental}

Utilizamos ratas Munich-Wistar com suas respectivas proles, compostas de 6 filhotes (entre machos e fêmeas). Durante os 20 primeiros dias de lactação, as matrizes receberam $L$ na dose de 250 mg/Kg/dia, diluído na água do bebedouro. A dose administrada aos animais já havia sido testada previamente em nosso laboratório [27], mostrando-se eficaz quanto ao efeito teratogênico desejado. O desmame dos filhotes ocorreu quando estes atingiram 25 dias de vida, ou seja, 5 dias após a interrupção da administração de L. Os filhotes machos foram então distribuídos em gaiolas onde tiveram livre acesso à água e à ração. Optamos por utilizar apenas os filhotes do sexo masculino, pois experimentos preliminares nos mostram que as fêmeas submetidas ao bloqueio do receptor AT1 durante a nefrogênese desenvolvem albuminúria menos proeminente do que os machos na mesma situação (Tabela 1). 
Tabela 1: Pressão caudal $(P C)$ e albuminúria $\left(U_{\text {alb }} V\right)$ dos animais tratados com losartan durante a lactação ( $\left.L_{\text {Lact }}\right)$, mensuradas aos 210 dias de vida:

\begin{tabular}{ccc} 
SEXO & PC & $\mathrm{U}_{\text {alb }} \mathrm{V}$ \\
\hline FÊMEAS L Lact & $146 \pm 4$ & $33 \pm 4$ \\
MACHOS L Lact & $146 \pm 6$ & $105 \pm 17$
\end{tabular}

\section{Grupos Experimentais}

Aos 210 dias de vida, quando o modelo experimental que utilizamos sabidamente já apresenta hipertensão arterial leve e dano renal avançado, [27] os ratos foram subdivididos em 5 grupos experimentais (Figura 1):

LLactPre: grupo pré-tratamento; estudados aos 210 dias (7meses) de vida.

$\mathrm{L}_{\text {Lact }}+\mathbf{V}$ : mantidos sem tratamento até os 300 dias (10 meses) de vida.

$\mathrm{L}_{\text {Lact }}+\mathrm{L}$ : tratados com L, $50 \mathrm{mg} / \mathrm{Kg} / \mathrm{dia}$, entre os 210 e 300 dias de vida.

$\mathrm{L}_{\text {Lact }}+\mathrm{H}$ : tratados com H, $6 \mathrm{mg} / \mathrm{Kg} / \mathrm{dia}$, entre os 210 e 300 dias de vida.

L Lact + LH: tratados com associação de L, $50 \mathrm{mg} / \mathrm{Kg} / \mathrm{dia}$ e H, $6 \mathrm{mg} / \mathrm{Kg} / \mathrm{dia}$, dos 210 aos 300 dias de vida.

Como controle para os experimentos foram utilizados ratos normais, que não receberam nenhum tratamento durante a lactação ou na vida adulta (Grupo C). Esses animais foram estudados também aos 300 dias de vida. 


\section{Protocolo Experimental}

Para o desenvolvimento deste protocolo experimental foram utilizados 103 ratos Munich Wistar machos (17 L Lact $P r e, 19 \mathrm{C}, 15 \mathrm{~L}_{\text {Lact }}+\mathrm{V}, 19 \mathrm{~L}_{\text {Lact }}+\mathrm{L}, 17$ $\mathrm{L}_{\text {Lact }}+\mathrm{H}$ e $\left.16 \mathrm{~L}_{\text {Lact }}+\mathrm{LH}\right)$. O peso corpóreo (PE, g) foi monitorado semanalmente e, a partir dos 90 dias de vida, todos os animais passaram a ser colocados em gaiolas metabólicas trimestralmente para a determinação da taxa de excreção urinária de albumina em 24 horas através da técnica de imunodifusão radial [56]. Foi realizada também medida trimestral da pressão arterial caudal (PAC, mmHg), utilizando um método opto-eletrônico (BP 2000 Blood Pressure Analysis Syste, Visitech Systems, Apex, North Carolina, Estados Unidos).

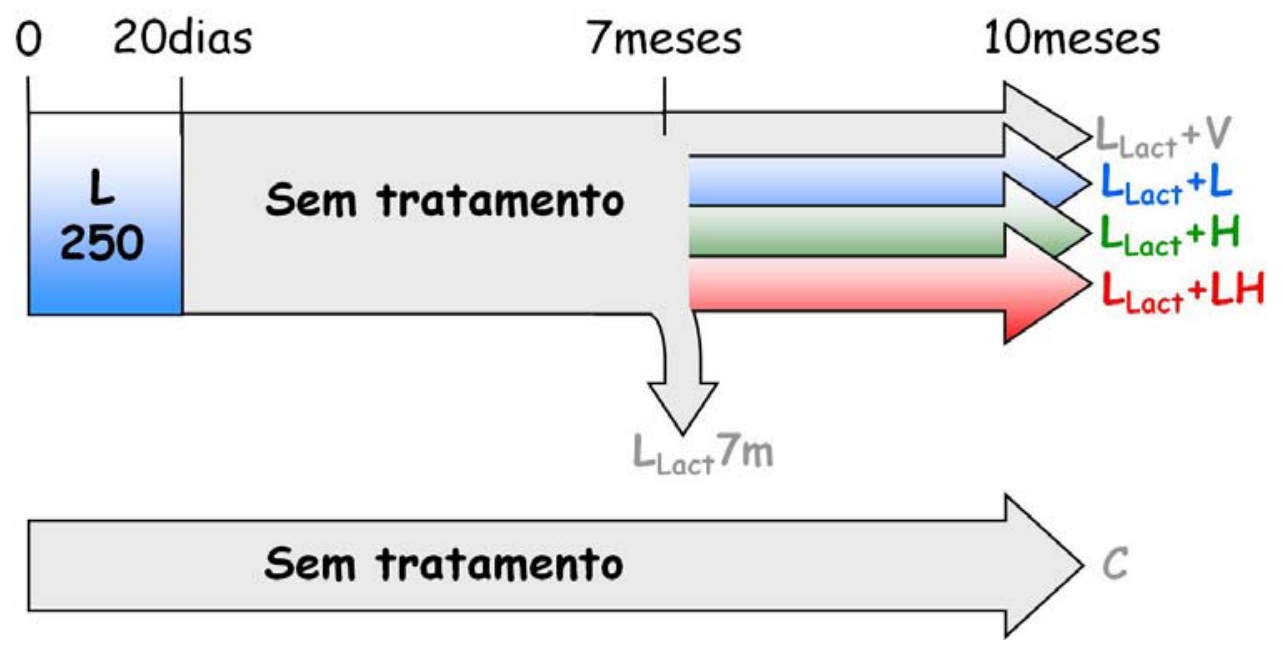

Fig.1: Esquema do protocolo experimental utilizado no estudo.

\section{Análises bioquímicas e eutanásia}

A partir dos 90 dias de vida os animais foram colocados trimestralmente em gaiolas metabólicas durante 24 horas para a coleta de urina total. Essas amostras foram avaliadas quanto ao volume urinário $\left(U_{v}\right.$, 
$\mathrm{ml} / 24 \mathrm{~h})$, concentração urinária de sódio $\left(U_{\mathrm{Na}}, \mathrm{mmol} / 24 \mathrm{~h}\right)$ e potássio $\left(U_{K}\right.$, $\mathrm{mmol} / 24 \mathrm{~h}$ ) e osmolaridade urinária $\left(\mathrm{U}_{\mathrm{osm}}, \mathrm{mOsm} / \mathrm{L}\right)$.

\section{Análise das Proteínas Urinárias}

A partir dos 90 dias de vida os animais foram colocados trimestralmente em gaiolas metabólicas durante 24 horas para a coleta de urina. A proteinúria foi analisada por meio da reação com o ácido sulfosalicílico, sendo dosada através de espectrofotometria. A concentração de albumina urinária, por sua vez, foi determinada por imunodifusão radial: Preparou-se um gel de agarose a $2 \%$ com tampão tris-barbital e anticorpo anti-albumina de rato (Cappel, Ohio, EUA). Aplicou-se 1,25 ml da mistura liquefeita em uma placa de imunodifusão radial sendo esta mantida em geladeira por no mínimo 4h para a solidificação do gel. Foram feitos orifícios circulares no centro de cada fileira das placas, onde foram aplicados $7,5 \mu \mathrm{l}$ das amostras de urina. Após $24 \mathrm{~h}$ as áreas dos halos formados nas placas foram lidas com régua apropriada para o cálculo da concentração de albumina [56].

\section{Obtenção do tecido renal e amostras de sangue}

Aos 210 (grupo $L_{\text {lact }}$ Pre) e 300 (todos os demais grupos) dias de vida os animais foram anestesiados com Ketamina (Cristália, $50 \mathrm{mg} / \mathrm{kg}$ ) e Rompun (Bayer, $10 \mathrm{mg} / \mathrm{kg}$ ) e submetidos a uma laparotomia mediana, sendo o rim direito retirado, seccionado em 4 a 6 porções iguais e imediatamente congelado em nitrogênio líquido para posterior realização da extração de 
proteínas e zimografia em gelatina. A seguir, a aorta abdominal foi ligada acima do rim esquerdo, enquanto que, um tubo de polietileno foi inserido na aorta logo abaixo da artéria renal. Amostras de sangue foram coletadas e o rim esquerdo foi perfundido "in situ" a uma pressão igual à sistêmica, inicialmente com solução salina, para uma breve lavagem e em seguida, com a solução Du Boscq-Brasil, para a fixação. Depois de fixado, o tecido renal foi pesado e preparado para os estudos histológicos e imunohistoquímicos. Cada rim foi seccionado em 2-3 segmentos coronais de 4-5 mm de espessura e pós-fixado em formaldeído a 10\% em tampão fosfato.

A reação do ácido periódico de Shiff (PAS) foi utilizada para a avaliação de lesões glomerulares e a coloração de Tricrômio de Masson para a quantificação de lesão intersticial. A técnica de imuno-histoquímica foi empregada na detecção de infiltração macrofágica e linfocitária intersticial, proliferação celular, bem como para avaliação de rarefação capilar no córtex renal. Através desta técnica também foi possível avaliar a percentagem de área intersticial ocupada por $\alpha$-actina de músculo liso, proteína utilizada como marcador de miofibroblastos, células intimamente relacionadas a progressão do processo inflamatório que leva à fibrose renal.

As amostras de sangue coletadas foram utilizadas para a determinação da concentração de sódio $\left(P_{\mathrm{Na}}, \mathrm{mmol} / \mathrm{L}\right)$ e potássio $\left(\mathrm{P}_{\mathrm{K}}\right.$, $\mathrm{mmol} / \mathrm{L})$ plasmáticos, bem como a osmolaridade plasmática $\left(\mathrm{P}_{\mathrm{osm}}, \mathrm{mOsm} / \mathrm{L}\right)$. A creatinina sérica foi quantificada empregando-se um kit disponível comercialmente (Labtest, Lagoa Santa, MG). Através das dosagens dos eletrólitos urinários e plasmáticos foram calculados; o clearance osmolar 
(Clear $\left.{ }_{\text {osm, }}, \mathrm{ml} / 24 \mathrm{~h}\right)$, dado pela equação: $\left[\left(\mathrm{U}_{\mathrm{osm}} / \mathrm{P}_{\mathrm{osm}}\right) \cdot \mathrm{U}_{\mathrm{v}}\right]$, o TC de água (TC $\mathrm{H}_{2} \mathrm{O}, \mathrm{ml} / 24 \mathrm{~h}$ ), dado por: Clear $_{o s m}-\mathrm{U}_{v}$, o quociente do $\mathrm{TC}_{2} \mathrm{O}$ de água pelo clearance osmolar: ( $\mathrm{TC}_{2} \mathrm{O} /$ Clear $_{\text {osm }}$ ) e o clearance de água livre (Clear $\left.\mathrm{H}_{2} \mathrm{O}, \mathrm{ml} / 24 \mathrm{~h}\right)$, dado por: $\mathrm{U}_{\mathrm{v}} \cdot\left[1-\left(\mathrm{U}_{\mathrm{osm}} / \mathrm{P}_{\mathrm{osm}}\right)\right]$.

\section{Histologia e Imuno-histoquímica}

Para os estudos histológicos e imuno-histoquímicos, os animais foram anestesiados e preparados para a perfusão conforme descrito anteriormente. Após a perfusão com solução salina, os rins foram perfundidos com solução de Du Boscq-Brasil para a fixação e estocados em solução de formaldeído a $10 \%$ em tampão fosfato de $\mathrm{pH} 7,4$. Os rins foram catalogados, etiquetados, colocados em recipientes perfurados de aço inoxidável, mantidos durante $14 \mathrm{~h}$ em um processador automático de tecidos (Jung Histokinette 2000, Leica Instruments GmbH, Nussloch, Alemanha), para a desidratação, diafanização e impregnação com parafina. Esse processo consiste em vários banhos de aproximadamente 90 minutos, primeiramente com concentrações crescentes de álcool $(50 \%, 70 \%, 96 \%$ e 100\%), a seguir em uma mistura 1:1 de álcool e xilol, em xilol puro e, por fim, em parafina fundida a $58^{\circ} \mathrm{C}$. Os rins foram então retirados do aparelho, incluídos em blocos de parafina e cortados em micrótomo. Os cortes histológicos (de $4 \mu \mathrm{m}$ ) foram montados em lâminas secas para a análise histológica e em lâminas silanizadas para imuno-histoquímica. Os cortes foram deixados em estufa a $58^{\circ} \mathrm{C}$ por $2 \mathrm{~h}$ para a fusão da parafina e adesão dos fragmentos às lâminas. 


\section{Estudo Histológico}

As lâminas contendo cortes de tecido renal com espessura de $4 \mu \mathrm{m}$ foram coradas empregando-se a reação do ácido periódico de Schiff (PAS), com o objetivo de quantificar as lesões glomerulares (GS) e a reação do tricrômico de Masson para a quantificação da expansão intersticial (INT\%).

O grau de GS de cada animal foi avaliado examinando-se sucessivamente um número de glomérulos nunca inferior a 150 em microscópio ótico em aumento final de 200X, atribuindo-se a cada glomérulo uma "nota" correspondente à extensão da lesão: 0, para glomérulos intactos; 1, para lesões acometendo $10 \%$ ou menos da superfície glomerular; 2 , para lesões afetando entre $10-20 \%$ do glomérulo; 3 , para lesões compreendendo entre 20-30 \% do glomérulo e assim por diante até a "nota" 10, correspondente à esclerose global do glomérulo. Um índice de esclerose glomerular (IEG) foi calculado para cada rato como média ponderada de todas as "notas" atribuídas a glomérulos individuais. Para avaliar a extensão da INT\%, a fração do córtex renal ocupada por tecido intersticial corado positivamente pelo tricrômico de Masson foi quantificada por um método de contagem de pontos. Foram avaliados 25 campos microscópicos consecutivos, num aumento final de $200 x$ com uma ocular graticulada de 144 pontos, obtendo-se um valor final, expresso em percentagem de expansão intersticial [57]. 


\section{Estudo Imuno-histoquímico}

Os métodos utilizados para o estudo imuno-histoquímico foram APAAP (Fosfatase Alcalina Anti-Fosfatase Alcalina), Estreptavidina AP (Estreptavidina-Fosfatase Alcalina) e Imunoperoxidase Indireta, descritos a seguir.

Após 30 minutos em estufa a $60^{\circ} \mathrm{C}$, as lâminas contendo os cortes de tecido renal de espessura de $4 \mu \mathrm{m}$ foram desparafinizadas através de uma seqüência de 3 banhos de xilol e reidratadas com uma bateria de banhos em concentrações decrescentes de etanol em água destilada: etanol 100\% (2 banhos), etanol $96 \%$, etanol $80 \%$ e água destilada. Foi realizada a recuperação antigênica com calor úmido, em solução de ácido cítrico $10 \mathrm{mM}$ tamponado, $\mathrm{pH} 6,0$ em temperatura aproximada de $95^{\circ} \mathrm{C}$ por 30 minutos. As lâminas foram resfriadas e posteriormente mergulhadas em solução tampão TBS (Tris buffer saline), pH 7,6. Todas as incubações foram realizadas em câmara úmida a fim de evitar o ressecamento dos cortes.

\section{Identificação de Macrófagos no interstício renal - Método APAAP}

O método de imuno-histoquímica APAAP (Fosfatase Alcalina AntiFosfatase Alcalina) foi empregado na identificação de macrófagos (MØ), através da presença do antígeno citoplasmático ED-1. Após desparafinização e exposição epitópica, as lâminas foram incubadas com soro não imune de coelho (Dako, Dinamarca), diluído a $5 \%$ em solução de albumina bovina (BSA) durante 30 minutos, a fim de bloquear ligações inespecíficas do anticorpo primário. Após este bloqueio, o excesso de soro 
foi retirado das lâminas e estas foram incubadas com anticorpo primário mouse anti-ED-1 (Serotec, Oxford, Reino Unido), diluído a 0,5\% em BSA a temperatura de $4^{\circ} \mathrm{C}$, em geladeira, por pelo menos $18 \mathrm{~h}$. No dia seguinte, as lâminas foram lavadas em TBS para a retirada do excesso de anticorpo primário e foram posteriormente incubadas com o anticorpo secundário anticamundongo desenvolvido em coelhos (Dako, Califórnia, EUA), diluído a 2\% em BSA, durante 30 minutos em câmara úmida, temperatura ambiente. Após nova lavagem com TBS, os cortes foram incubados com o complexo APAAP (Dako, Califórnia, EUA), diluído 1,4\% em BSA, durante 30 minutos em câmara úmida, temperatura ambiente e por fim revelados em tempo variável com substrato cromogênico Fast-Red. As células positivas para ED-1 puderam ser visualizadas devido à precipitação do produto da reação da fosfatase alcalina presente no complexo APAAP e do Fast-Red presente no substrato cromogênico.

Para o preparo do substrato cromogênico para esse método utilizouse; solução de 1mg de naftol AS-MX fosfato (Sigma, St. Louis, MO, EUA), $100 \mu \mathrm{l}$ de dimetilformamida, 4,9ml de solução Tris $0,1 \mathrm{M}$ de $\mathrm{pH}$ 8,2, $5 \mu \mathrm{l}$ de levamisol $1 \mathrm{M}$ e $5 \mathrm{mg}$ de Fast Red. Este substrato foi aplicado às lâminas a temperatura ambiente, em câmara úmida. A revelação das células positivas foi acompanhada ao microscópio e para a interrupção desta, as lâminas foram lavadas em TBS.

Após a revelação, realizou-se contracoloração com hematoxilina de Mayer por 2 minutos, após a qual as lâminas foram lavadas em água corrente e montadas com lamínula, utilizando-se meio de montagem aquoso 
contendo glicerina e gelatina. Ao final do procedimento, as lâminas foram devidamente etiquetadas.

A quantificação de $M \varnothing$ foi realizada através da contagem de células positivas para ED-1 em córtex renal com aumento final de 200X. Foram examinados 25 campos microscópicos corticais para cada seção, correspondendo a uma área cortical total de $1,6 \mathrm{~mm}^{2}$.

Identificação de Linfócitos intersticiais / Células intersticiais positivas para All / $\alpha$-Actina intersticial - Método Streptavidina AP

O método Streptavidina AP (Streptavidina Fosfatase Alcalina) foi empregado para a identificação de linfócitos (através do antígeno CD3 presente em linfócitos T maduros ativados), bem como para células positivas para All e também para a marcação de áreas intersticiais do parênquima renal ocupadas por $\alpha$-actina. Esta última, constitutiva de vasos sangüíneos, é comumente observada no compartimento intersticial na vigência de fibrose renal e pode ser indicativa da presença de miofibroblastos; células características do processo de cicatrização do parênquima renal que leva à perda de função do órgão.

Após desparafinização e exposição de epítopos, os cortes foram incubados com soluções-bloqueio de Avidina e Biotina (Vector, Califórnia, EUA) durante 15 minutos cada, a fim de evitar a marcação inespecífica destes componentes. Em seguida, as lâminas foram incubadas com soro não imune de cavalo (Vector Lab, Burlingame, EUA), diluído a $2 \%$ em solução de leite desnatado a $2 \%$ em TBS, durante 30 minutos, em câmara 
úmida, a temperatura ambiente. Esta incubação tem por objetivo evitar ligações inespecíficas do anticorpo primário. Após a retirada do excesso de soro, os cortes foram incubados com os anticorpos primários; anti-CD3 desenvolvido em camundongos (Dako, Califórnia, EUA), diluído a 1\%, antiangiotensina II, desenvolvido em coelhos (Peninsula Laboratories, Inc., EUA), diluído a $0,25 \%$, ou anti- $\alpha$-actina de músculo liso, desenvolvido em camundongos (Sigma, St. Louis, MO, Estados Unidos) diluído a 0,12\% em $\mathrm{BSA}$, a temperatura de $4^{\circ} \mathrm{C}$, em geladeira, durante $18 \mathrm{~h}$. No dia seguinte, as lâminas foram lavadas em TBS para a retirada do excesso de anticorpo primário e os cortes foram incubados com o anticorpo secundário biotinilado anti-coelho (Vector Laboratories, Califórnia, EUA), diluído $0,1 \%$ ou biotinilado anti-camundongo (Vector Laboratories, Califórnia, EUA), diluído 0,5 \% em BSA, por 45 minutos a temperatura ambiente, em câmara-úmida. As lâminas foram novamente lavadas em TBS e em seguida os cortes foram incubados com o complexo Estreptavidina-Fosfatase Alcalina (Dako, Califórnia, EUA) diluído a 1,8\% em solução de Tris Hidrocloride (Tris-HCl) 0,5M, durante 30 minutos, a temperatura ambiente, em câmara úmida. As lâminas foram então lavadas em TBS, reveladas com substrato cromogênico a base de Fast Red, contracoradas e montadas como descrito anteriormente.

A quantificação dos linfócitos, bem como da angiotensina II foi realizada através de contagem das células marcadas em córtex renal com aumento de 200 vezes. Foram examinados 25 campos microscópicos consecutivos para cada seção, correspondendo a uma área total de 1,6 $\mathrm{mm}^{2}$. 
Para a quantificação da área intersticial preenchida por $\alpha$-actina, foi utilizado o mesmo método de contagem de pontos descrito para a quantificação de área intersticial corada positivamente para o tricrômio de Massom; no entanto áreas ocupadas por vasos sanguíneos, ainda que marcados positivamente, não foram incluídas na quantificação.

\section{Identificação de Células em Processo de Proliferação / Vasos Capilares}

Peritubulares e Vasos Capilares Glomerulares - Método da Imunoperoxidase Indireta

O método da Imunoperoxidase Indireta foi empregado para a detecção de células em processo de proliferação, através do antígeno PCNA (Proliferating Cell Nuclear Antigen), presente nas células durante a fase $\mathrm{S}$ do ciclo celular; bem como para a identificação de vasos capilares peritubulares e glomerulares, através do antígeno Aminopeptidase-P (JG12), presente nas células endoteliais dos vasos sanguíneos.

Após desparafinização e exposição de epítopos, os cortes foram incubados com uma solução de Peróxido de Hidrogênio 10 volumes a $30 \%$ em Álcool Metílico durante 30 minutos, a fim de bloquear a atividade da enzima peroxidase endógena. Em seguida, as lâminas foram incubadas com soro não imune de cavalo (Vector Lab, Burlingame, EUA), diluído a $2 \%$ em solução de leite desnatado a $2 \%$ em TBS, durante 30 minutos, em câmara úmida, a temperatura ambiente. Esta incubação tem por objetivo evitar ligações inespecíficas do anticorpo primário. Após a retirada do excesso de soro, os cortes foram incubados com os anticorpos primários; anti-PCNA 
desenvolvido em camundongos (Dako, Califórnia, EUA) e antiaminopeptidase P desenvolvido em camundongos (Bender Med Systems, Califórnia, EUA) diluídos a $1 \%$ em BSA, a temperatura de $4^{\circ} \mathrm{C}$, em geladeira, durante 18h. No dia seguinte as lâminas foram lavadas em TBS e os cortes foram incubados primeiramente com uma solução de bloqueio pós-primário, seguida de uma solução de anticorpo anti-camundongo associado à enzima peroxidase (Novolink ${ }^{\circledR}$ - Novocastra, United Kingdom). As lâminas foram então lavadas em TBS, reveladas com substrato cromogênico a base de Diaminobenzidina, contracoradas e montadas como descrito anteriormente.

A quantificação das células intersticiais em processo de proliferação foi realizada através de contagem das células marcadas em córtex renal com aumento de 200 vezes. Foram examinados 25 campos microscópicos consecutivos para cada seção, correspondendo a uma área total de 1,6 $\mathrm{mm}^{2}$. Para a quantificação das células tubulares em processo de proliferação foi elaborada uma razão entre o número de células tubulares marcadas positivamente para o antígeno PCNA e o número total de túbulos renais em 25 campos microscópicos sob aumento de 200X.

Os vasos capilares peritubulares foram quantificados através da contagem do número total de vasos marcados positivamente para Aminopeptidase-P no córtex renal, em um total de 25 campos sob aumento de 200 vezes, correspondendo a uma área total de $1,6 \mathrm{~mm}^{2}$. Adicionalmente foi realizada uma contagem do número total de perfis tubulares renais presentes nesses mesmos campos a fim de se obter uma relação do número de capilares peritubulares por túbulo renal, com o objetivo de minimizar a 
subestimação de vasos sanguíneos nos animais cujo parênquima renal encontra-se acometido por expansão intersticial, atrofia e dilatação tubular. A quantificação dos capilares glomerulares foi obtida a partir da percentagem da área glomerular ocupada por marcação positiva para Aminopeptidase-P em 25 glomérulos sob aumento de 200X, para cada animal.

\section{Determinação da atividade das metaloproteinases 2 e 9 através de}

\section{zimografia em gelatina}

Sabe-se que o estabelecimento da fibrose renal resulta, em última instância, da síntese exacerbada de proteínas de matriz extracelular (MEC), aliada a incapacidade das metaloproteinases (MMPs) teciduais (proteases que realizam a degradação de matriz, promovendo renovação) de eliminar este excesso. Dessa forma, grande quantidade de proteínas de matriz se acumula no espaço intersticial.

Com o objetivo de verificar se o precoce acúmulo de MEC observado no modelo estudado deve-se a alterações na quantidade ou atividade das metaloproteinases, realizou-se a zimografia em gelatina. Para a execução desta técnica, procedeu-se a extração das proteínas totais do tecido renal dos animais, seguida de eletroforese dessas proteínas, incubação em solução de ativação enzimática e posterior quantificação da atividade proteolítica das metaloproteinases presentes no tecido, conforme descrito a seguir. 


\section{Extração de proteínas}

Os fragmentos renais foram congelados em nitrogênio líquido momentos antes da perfusão e armazenados em freezer a uma temperatura de $-80^{\circ} \mathrm{C}$. Cada fragmento de rim congelado foi imerso em cerca de $2 \mathrm{ml}$ de solução de lise e homogeneizado com auxílio de um dispersor de tecidos (IKA - Labortechnik Ultra Turrax T25 Janke \& Kunkel, Alemanha). Em seguida, este homogenato foi centrifugado durante 15 minutos a 10.000 RPM a $4^{\circ} \mathrm{C}$ e a concentração de proteínas no sobrenadante foi determinada através do método colorimétrico de Bradford [58].

\section{Eletroforese das proteínas em gel de acrilamida/gelatina e reação de digestão enzimática}

Com o objetivo de separar as proteínas dos extratos protéicos obtidos de acordo com seus pesos moleculares, realizou-se uma corrida eletroforética vertical em gel de acrilamida contendo gelatina. Uma vez realizada a corrida, os géis foram mantidos por 72 horas em uma solução de ativação enzimática em temperatura aproximada de $37^{\circ} \mathrm{C}$. O propósito desta etapa foi permitir que as metaloproteinases (em especial as gelatinases) presentes nos diferentes extratos protéicos consumissem a gelatina presente no gel de acrilamida, formando assim bandas "negativas" na posição correspondente a seu peso molecular. 


\section{Quantificação da atividade das gelatinases}

Os géis foram corados com Coomassie Blue e fotografados. As bandas "negativas" formadas pela atividade das gelatinases presentes nos extratos protéicos renais foram então quantificadas com o auxílio do software IMAGE $\mathrm{J}^{\circledR}$ para processamento de imagens. Os resultados foram apresentados como uma razão entre a atividade das metaloproteinases nos diferentes grupos experimentais, sobre a atividade dessas mesmas enzimas no parênquima renal dos animais $\mathrm{C}+\mathrm{V}$, usados como referência.

\section{Análise Estatística}

Os resultados deste estudo foram analisados através da comparação entre os grupos. Foi empregada a análise de variância one-way ANOVA com pós-teste de Tukey, sendo considerados significativos os valores de "p" inferiores a 0,05. As correlações foram estabelecidas através de regressão linear. Todos os cálculos foram efetuados através do software GraphPad Prism® versão 4.0 e os resultados foram apresentados como média \pm erro padrão [59]. 


\section{RESULTADOS}

\section{PARÂMETROS GERAIS DE FUNCÃ̃O RENAL E SISTÊMICA}

Conforme apresentado na Tabela 2, a sobrevida dos animais C e $L_{\text {Lact }}$ Pre foi de $100 \%$. Aos 300 dias de vida, os animais $L_{\text {Lact }}+V$ apresentaram sobrevida de $76 \%$, enquanto que os grupos $\mathrm{L}_{\text {Lact }}+\mathrm{L}$, $\mathrm{L}_{\text {Lact }}+\mathrm{H}$ e $\mathrm{L}_{\text {Lact }}+\mathrm{LH}$ alcançaram sobrevida de $100 \%, 94 \%$ e $94 \%$, respectivamente. O peso corpóreo dos animais dos diferentes grupos foi verificado diariamente e observou-se que, somente o grupo $\mathrm{L}_{\text {Lact }} P r e$ apresentou peso corpóreo inferior aos demais grupos, uma vez que se trata de ratos mais jovens e, portanto, mais leves. (Tabela 2 e Figura 2).

Não foram observadas diferenças quanto à concentração plasmática de sódio, bem como quanto à osmolaridade plasmática entre os diferentes grupos experimentais. No entanto, os animais do grupo $L_{\text {Lact }}+L$ apresentaram uma tendência ao desenvolvimento de hipercalemia, conforme apresentado na Tabela 2 e detalhado na Figura 7. Adicionalmente, o fluxo urinário (Tabela 2 e Figura 4) e o quociente do TC de água sobre o clearance osmolar de todos os grupos de animais submetidos ao bloqueio do SRAA apresentou-se aumentado, ao passo que a osmolaridade urinária medida mostrou-se significativamente reduzida nesses mesmos animais (Tabela 2).

Os animais $L_{\text {Lact }}$ de maneira geral apresentaram clearance de água livre numericamente maior do que o observado nos animais controle, porém, essa diferença não foi estatisticamente significativa. A saber; todos os animais tiveram livre acesso à dieta, e não foi observada qualquer diferença quanto ao consumo diário de ração entre os grupos (Tabela 2). 
Tabela 2: Parâmetros gerais de função renal e sistêmica

\begin{tabular}{|c|c|c|c|c|c|c|}
\hline & $\underset{(\mathrm{n}=19)}{C}$ & $\begin{array}{c}L_{\text {Lact }} \text { Pre } \\
(\mathrm{n}=17)\end{array}$ & $\begin{array}{c}L_{\text {Lact }}+V \\
(\mathrm{n}=15)\end{array}$ & $\begin{array}{c}L_{\text {Lact }}+L \\
(\mathrm{n}=19)\end{array}$ & $\begin{array}{c}L_{\text {Lact }}+H \\
(\mathrm{n}=17)\end{array}$ & $\begin{array}{c}L_{\text {Lact }}+L \boldsymbol{H} \\
(\mathrm{n}=16)\end{array}$ \\
\hline Sobrevida & $100 \%$ & $100 \%$ & $76 \%$ & $100 \%$ & $94 \%$ & $94 \%$ \\
\hline Peso corpóreo(g) & $423 \pm 7$ & $388 \pm 7^{a}$ & $391 \pm 10$ & $401 \pm 9$ & $393 \pm 8$ & $393 \pm 7$ \\
\hline $\boldsymbol{P}_{\mathrm{Na}}(\mathrm{mmol} / \mathrm{L})$ & $139 \pm 1$ & $136 \pm 2$ & $140 \pm 1$ & $142 \pm 2$ & $142 \pm 1$ & $139 \pm 2$ \\
\hline $\boldsymbol{P}_{\boldsymbol{K}}(\mathrm{mmol} / \mathrm{L})$ & $4,7 \pm 0,1$ & $4,4 \pm 0,2$ & $5,0 \pm 0,2$ & $5,3 \pm 0,1^{\mathrm{ab}}$ & $4,6 \pm 0,1^{d}$ & $5,0 \pm 0,2$ \\
\hline $\boldsymbol{P}_{\text {osm }}(\mathrm{mOsm} / \mathrm{L})$ & $274 \pm 2$ & $272 \pm 3$ & $280 \pm 3$ & $284 \pm 4$ & $285 \pm 2$ & $277 \pm 3$ \\
\hline $\boldsymbol{U}_{\boldsymbol{v}}(\mathrm{ml} / 24 \mathrm{~h})$ & $35 \pm 2$ & $55 \pm 4^{a}$ & $75 \pm 5^{\mathrm{ab}}$ & $62 \pm 4^{a}$ & $61 \pm 3^{a}$ & $68 \pm 3^{a}$ \\
\hline $\boldsymbol{U}_{\text {osm }}(\mathrm{mOsm} / \mathrm{L})$ & $963 \pm 72$ & $659 \pm 46^{a}$ & $604 \pm 45^{a}$ & $636 \pm 37^{a}$ & $658 \pm 47^{a}$ & $573 \pm 42^{a}$ \\
\hline$U_{\mathrm{Na}} 24 h(\mathrm{mmol} / 24 \mathrm{~h})$ & $1,1 \pm 0,1$ & $1,3 \pm 0,1$ & $1,9 \pm 0,2^{\mathrm{ab}}$ & $1,3 \pm 0,1^{c}$ & $1,5 \pm 0,1$ & $1,4 \pm 0,1$ \\
\hline $\boldsymbol{U}_{K} \mathbf{2 4 h}(\mathrm{mmol} / 24 \mathrm{~h})$ & $3,2 \pm 0,1$ & $3,2 \pm 0,2$ & $3,8 \pm 0,2$ & $3,7 \pm 0,1$ & $3,7 \pm 0,1$ & $3,9 \pm 0,1$ \\
\hline Clear $_{\text {osm }}(\mathrm{ml} / 24 \mathrm{~h})$ & $129 \pm 3$ & $131 \pm 7$ & $143 \pm 7$ & $134 \pm 4$ & $138 \pm 9$ & $142 \pm 7$ \\
\hline $\mathrm{TC} \mathrm{H}_{2} \mathrm{O}(\mathrm{ml} / 24 \mathrm{~h})$ & $92 \pm 4$ & $75 \pm 7$ & $76 \pm 7$ & $75 \pm 4$ & $71 \pm 10$ & $70 \pm 6$ \\
\hline TC $\mathrm{H}_{2} \mathrm{O} / \mathrm{Clear}_{\text {osm }}$ & $0,71 \pm 0,03$ & $0,56 \pm 0,03^{a}$ & $0,53 \pm 0,04^{a}$ & $0,56 \pm 0,03^{a}$ & $0,52 \pm 0,04^{a}$ & $0,50 \pm 0,03^{a}$ \\
\hline Dieta (g/24h) & $22 \pm 1$ & $24 \pm 3$ & $24 \pm 1$ & $24 \pm 1$ & $24 \pm 1$ & $24 \pm 1$ \\
\hline
\end{tabular}

Os resultados estão apresentados como média \pm erro padrão:

a: $p<0,05$ vs. $C, \mathbf{b}: p<0,05$ vs. $L_{\text {Lact }} P r e, c: L_{L a c t}+V, d: L_{L a c t}+L, e: p<0,05$ vs. $L_{L a c t}+H$ 


\section{PESO CORPÓREO}

Conforme apresentado na Tabela 2, os animais do grupo $\mathrm{L}_{\text {Lact }} P r e$ apresentaram peso corpóreo inferior aos animais do grupo C, uma vez que se trata de ratos mais jovens. Aos 300 dias de vida não foram observadas diferenças de peso entre os diversos grupos (Figura 2).

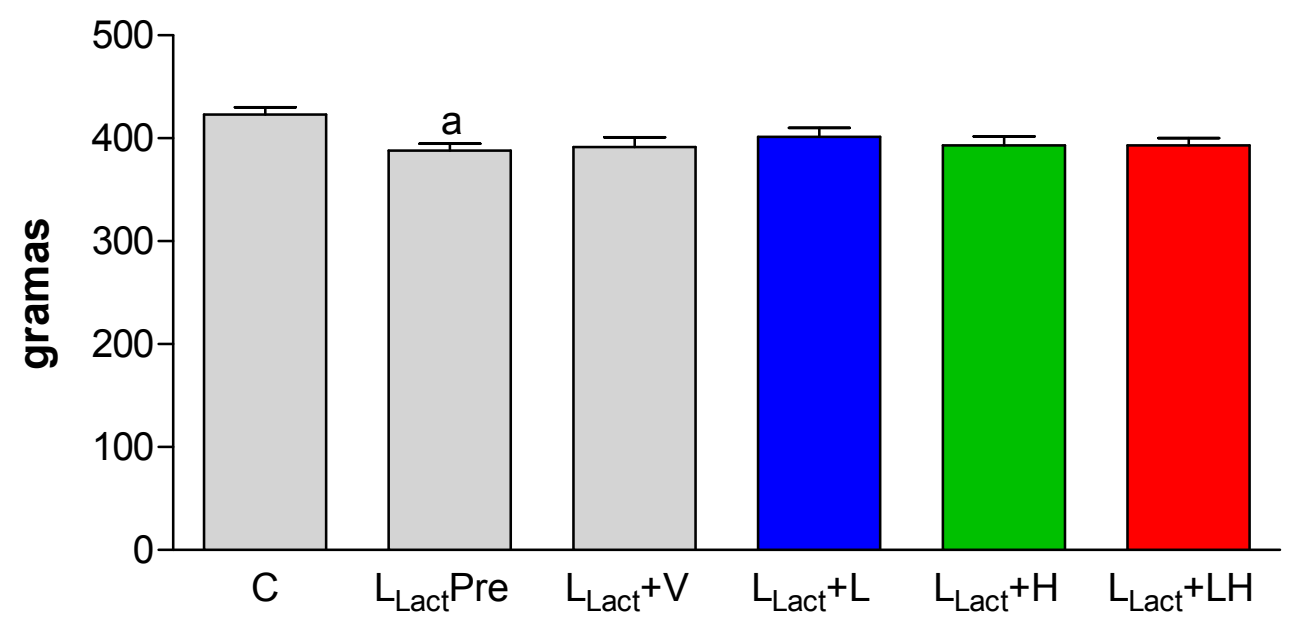

Fig.2: Peso corpóreo aos 300 dias de vida

a: $p<0,05$ vs. $C, \mathbf{b}: p<0,05$ vs. $L_{\text {Lact }} P r e, c: L_{\text {Lact }}+V, d: L_{\text {Lact }}+L$, e: $p<0,05$ vs. $L_{\text {Lact }}+H$ 


\section{PRESSÃO CAUDAL}

A pressão sistólica caudal (Figura 3) foi verificada trimestralmente. Ao final do estudo, ou seja, aos 300 dias de vida, os animais dos grupos $\mathrm{L}_{\text {Lact }}+\mathrm{V}$ apresentaram pressão arterial elevada em relação aos animais do grupo $\mathrm{C}+\mathrm{V}(187 \pm 5 \mathrm{mmHg}$ vs. $149 \pm 3$, respectivamente, $\mathrm{p}<0,05)$. Tanto as monoterapias como o tratamento associado impediram o desenvolvimento de hipertensão, mantendo a PA em nível igual ou até inferior ao observado no grupo pré-tratamento ( $\left.L_{\text {Lact }} P r e\right)$. A monoterapia com $L$, bem como a associação terapêutica $\mathrm{L}+\mathrm{H}$, reduziram os valores de pressão caudal a níveis inferiores àqueles observados no grupo $\mathrm{C}(130 \pm 3$ e $126 \pm 3 \mathrm{mmHg}$, respectivamente, $p<0,05)$.

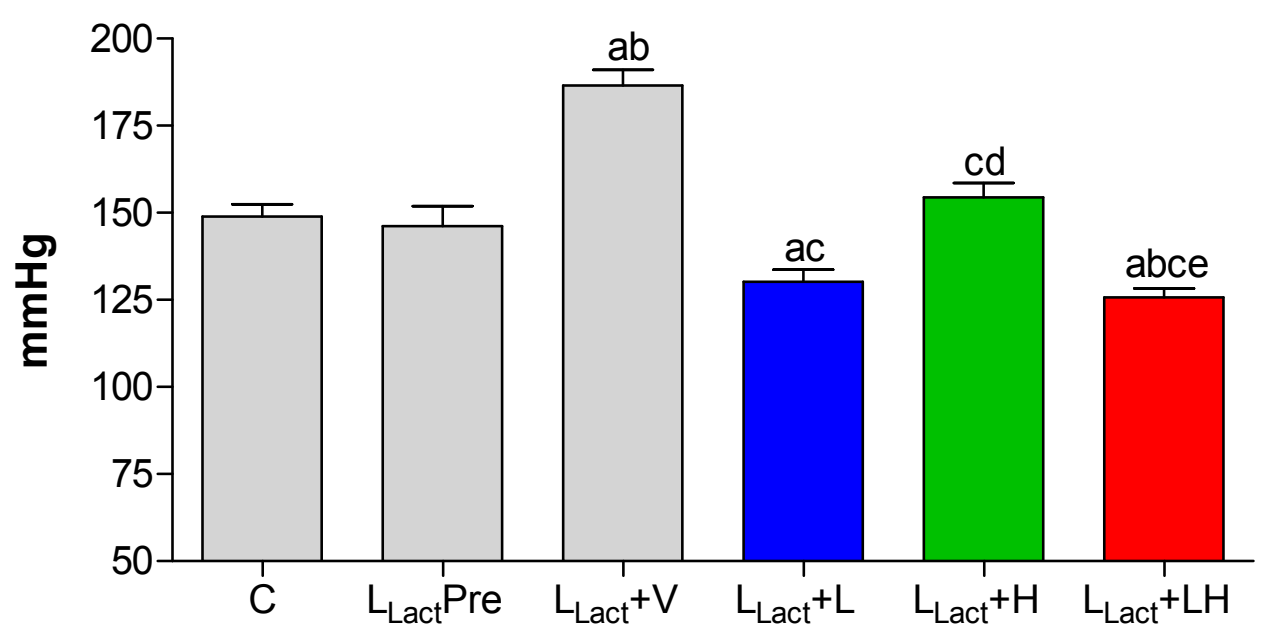

Fig.3: Pressão caudal aos 300 dias de vida

a: $p<0,05$ vs. $C, \mathbf{b}: p<0,05$ vs. $L_{\text {Lact }} P r e, c: L_{L a c t}+V, d: L_{L a c t}+L, e: p<0,05$ vs. $L_{L a c t}+H$ 


\section{FLUXO URINÁRIO}

De acordo com os dados apresentados na tabela 2, o fluxo urinário dos animais do grupo $L_{\text {Lact }}+\bigvee$ mostrou-se, como esperado, significativamente superior àquele observado nos animais do grupo C $(75 \pm 5$ e $35 \pm 2 \mathrm{ml}$, respectivamente, $p<0,05)$, conforme representado na Figura 4, sugerindo uma redução da capacidade renal de concentrar a urina [20] Todos os tratamentos reduziram numérica, mas não significativamente, a poliúria apresentada pelos animais, mantendo em valores semelhantes àqueles observados no grupo pré-tratamento.

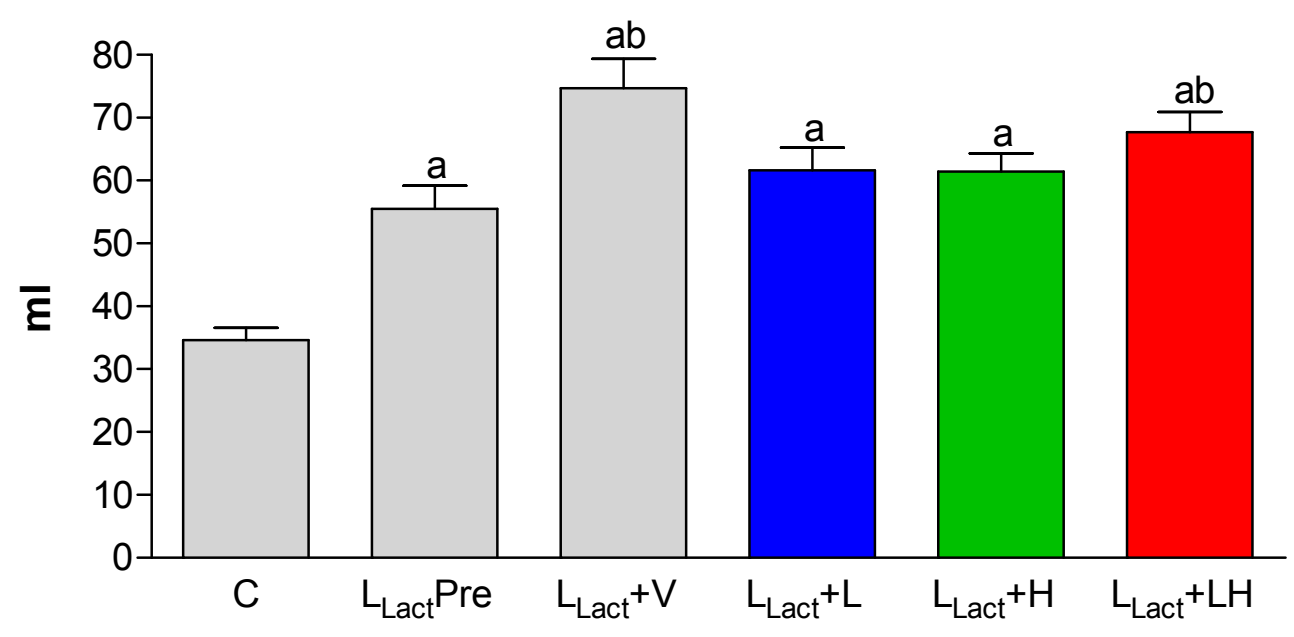

Fig.4: Volume urinário em 24 horas aos 300 dias de vida

a: $p<0,05$ vs. $C, b: p<0,05$ vs. $L_{\text {Lact }} P r e, c: L_{L a c t}+V, d: L_{\text {Lact }}+L, e: p<0,05$ vs. $L_{\text {Lact }}+H$ 


\section{ALBUMINÚRIA}

Os animais do grupo $\mathrm{L}_{\mathrm{Lact}}+\mathrm{V}$ apresentaram, já aos 210 dias de vida, uma albuminúria marcante $(150 \pm 14$ vs. C: $33 \pm 7 \mathrm{mg} / 24 \mathrm{~h}, \mathrm{p}<0,05)$, que intensificou-se com o passar do tempo, atingindo valores especialmente altos aos 300 dias de vida $(160 \pm 26 \mathrm{mg} / 24 \mathrm{~h})$. Todos os tratamentos empregados foram eficazes em impedir a progressão da albuminúria, mantendo-a em valores comparáveis ou até inferiores aos observados nos animais do grupo pré-tratamento (Figura 5).

Observou-se adicionalmente que os grupos tratados com L (monoterapia ou em associação com $\mathrm{H}$ ) manifestaram valores de albuminúria inferiores àqueles do grupo pré-tratamento e muito próximos aos valores exibidos pelo grupo $\mathrm{C}$.

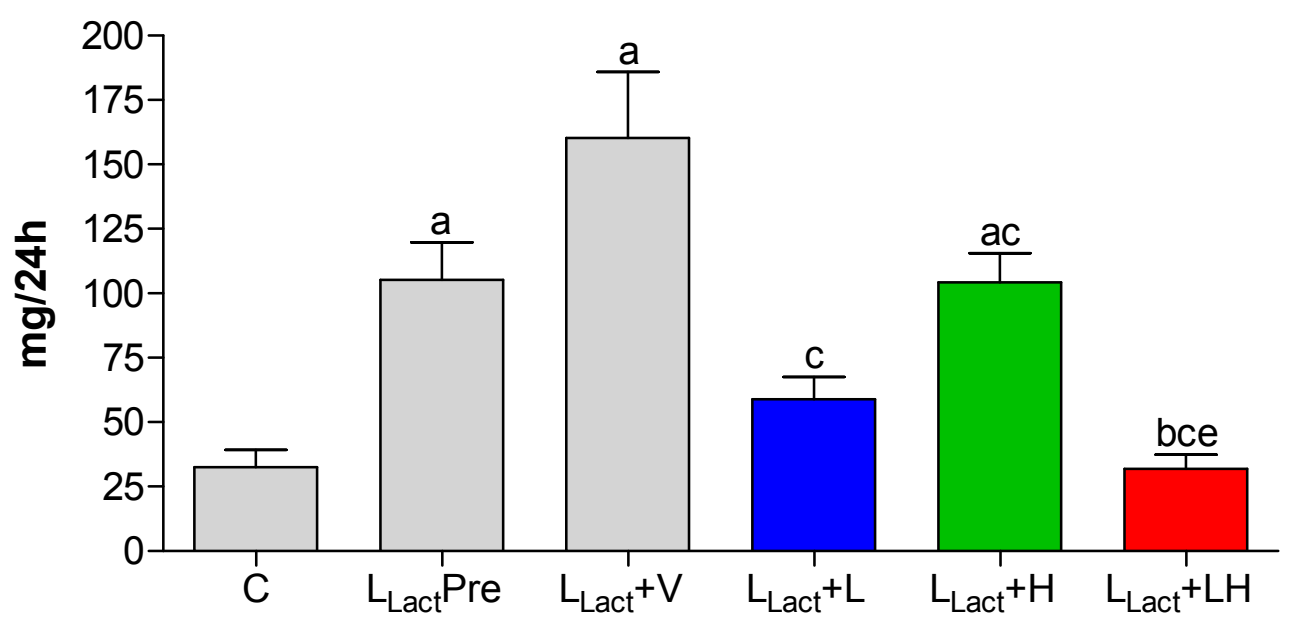

Fig.5: Excreção urinária de albumina aos $\mathbf{3 0 0}$ dias de vida a: $p<0,05$ vs. $C, \mathbf{b}: p<0,05$ vs. $L_{\text {Lact }} P r e, c: L_{L a c t}+V, d: L_{L a c t}+L$, e: $p<0,05$ vs. $L_{\text {Lact }}+H$ 


\section{CONCENTRAC̨ÃOSÉRICA DE CREATININA}

As concentrações de creatinina sérica observadas aos 300 dias de vida dos animais estão representadas na Figura 6. Observou-se que os animais do grupo $\mathrm{L}_{\mathrm{Lact}}+\mathrm{V}$ apresentaram valores elevados de creatinina sérica, estatisticamente superiores àqueles encontrados no grupo C, $(1,12 \pm 0,07$ vs. $0,69 \pm 0,04 \mathrm{mg} / \mathrm{dL}, \mathrm{p}<0,05)$, indicando comprometimento de função renal.

Nenhuma das monoterapias foi eficaz para impedir o aumento da concentração de creatinina no soro dos animais, no entanto a associação L + $\mathrm{H}$ manteve a creatinina sérica dos componentes do grupo $L_{\text {Lact }}+\mathrm{LH}$ em valores estatisticamente compatíveis com os observados no grupo prétratamento $\left(L_{\text {Lact }} P r e\right)$.

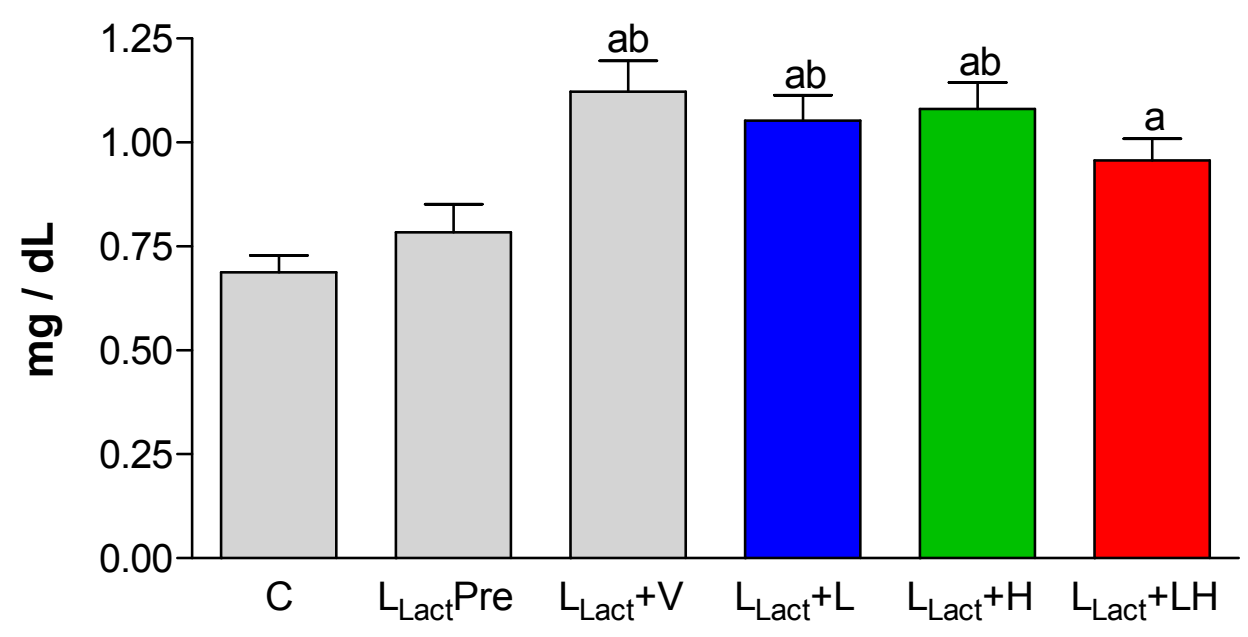

Fig.6: Concentração de creatinina sérica aos 300 dias de vida a: $p<0,05$ vs. $C, \mathbf{b}: p<0,05$ vs. $L_{\text {Lact }} P r e, c: L_{L a c t}+V, d: L_{L a c t}+L$, e: $p<0,05$ vs. $L_{\text {Lact }}+H$ 


\section{CONCENTRAČ̃̃O PLASMÁTICA DE POTÁSSIO}

A dosagem plasmática de potássio, representada na Figura 7 , indicou um aumento significativo da concentração deste cátion apenas nos animais do grupo $L_{\text {Lact }}+\mathrm{L}$, quando comparados ao grupo controle $(5,3 \pm 0,2 \mathrm{mEq} / \mathrm{dL}$ vs. C: $4,8 \pm 0,1$, respectivamente, $p<0,05)$.

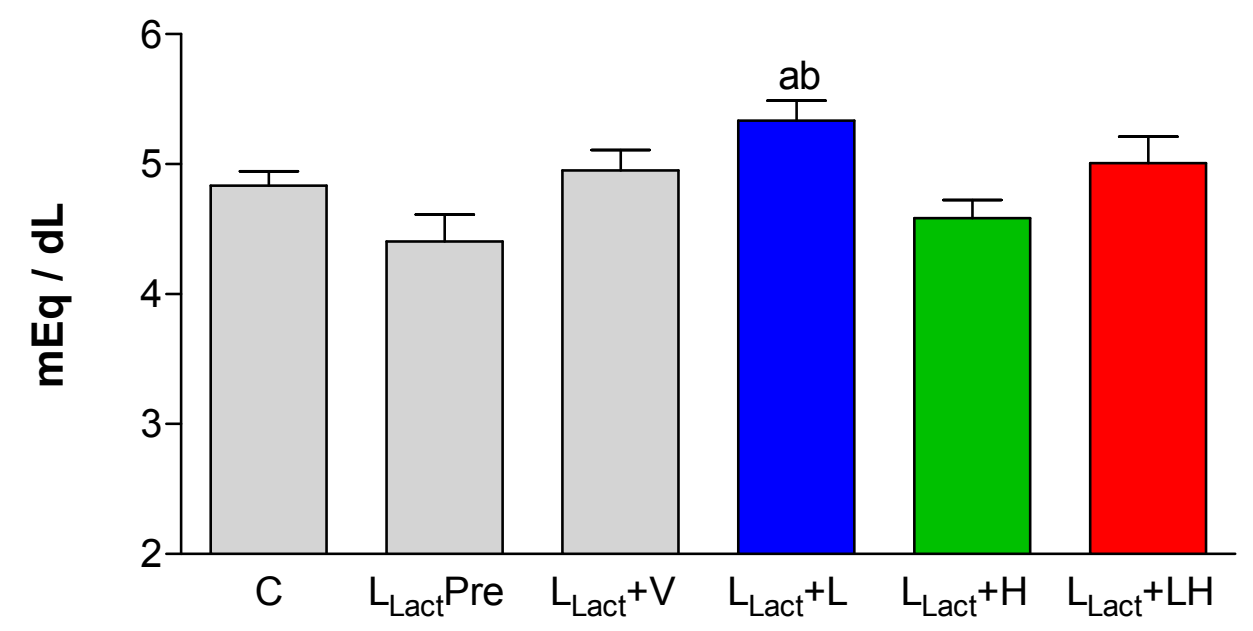

Fig.7: Concentração plasmática de potássio aos 300 dias de vida a: $p<0,05$ vs. $C$, b: $p<0,05$ vs. $L_{\text {Lact }} P r e, c: L_{\text {Lact }}+V, d: L_{\text {Lact }}+L, e: p<0,05$ vs. $L_{\text {Lact }}+H$ 


\section{PESO RENAL CORRIGIDO PELO PESO CORPÓREO}

Na data do sacrifício, o rim esquerdo de cada animal foi pesado e esse valor foi dividido pelo valor do peso corpóreo do mesmo animal e em seguida multiplicado por 1000 , com a finalidade de se obter um valor de peso renal corrigido. Não foram observadas diferenças no peso entre os diferentes grupos (Figura 8).

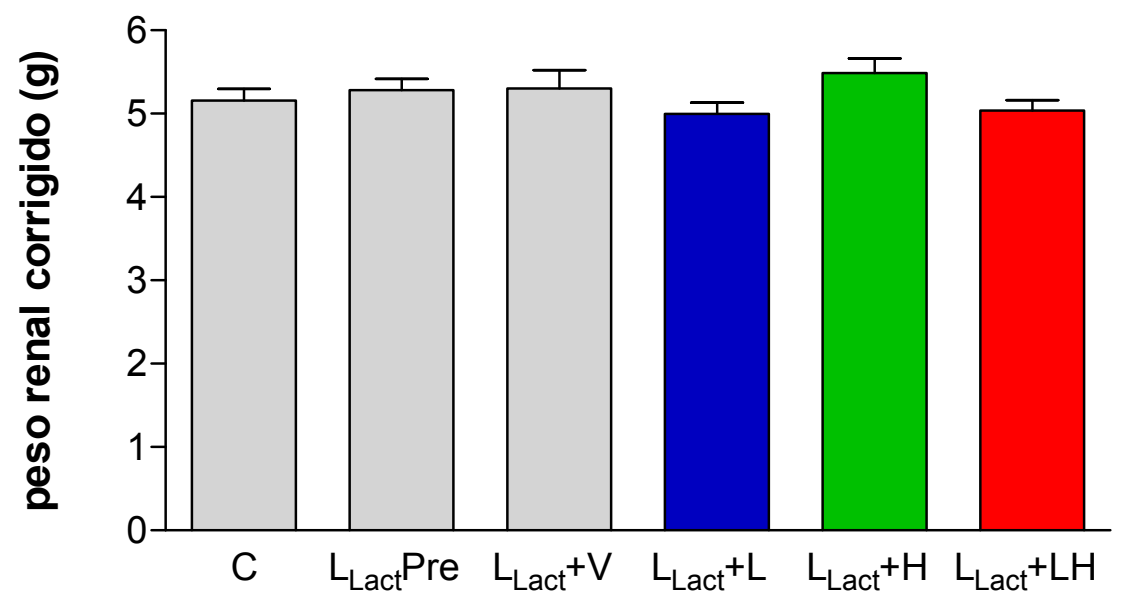

Fig.8: Peso renal corrigido

a: $p<0,05$ vs. $C$, b: $p<0,05$ vs. $L_{\text {Lact }} P r e, c: L_{L a c t}+V, d: L_{\text {Lact }}+L$, e: $p<0,05$ vs. $L_{\text {Lact }}+H$ 
HISTOLOGIA

\section{ATROFIA MEDULAR E PAPILAR: ANÁLISE MACROSCÓPICA}

$\mathrm{Na}$ análise macroscópica dos rins dos animais dos diferentes grupos experimentais observou-se acentuada atrofia da medula e papila renal naqueles animais submetidos ao bloqueio do SRAA durante a lactação (Figura 9).

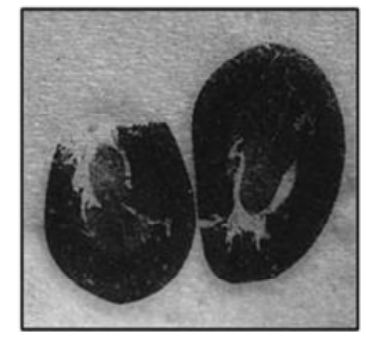

C

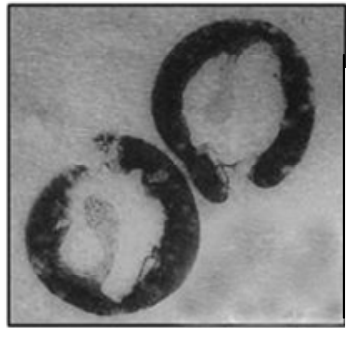

$L_{\text {Lact }}$ Pre

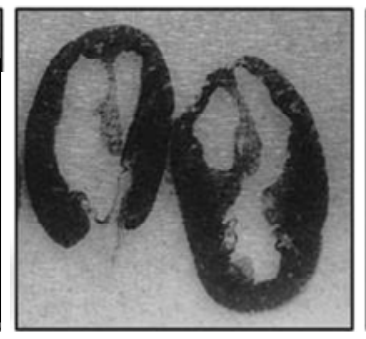

$L_{\text {Lact }}+\mathbf{V}$

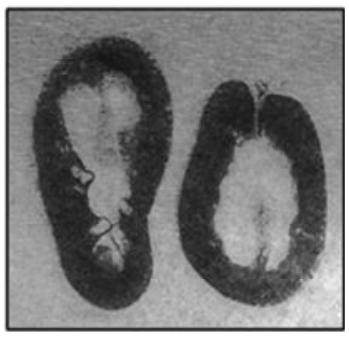

$\mathrm{L}_{\text {Lact }}+\mathrm{LH}$

Fig.9: Cortes histológicos de tecido renal, coloração PAS (1X)

As fotos foram convertidas para preto-e-branco a fim de evidenciar os contornos do parênquima renal, tornando mais visível a atrofia medular presente nos animais $L_{\text {Lact. }}$. 


\section{ESCLEROSE GLOMERULAR}

Analisando-se os índices de esclerose glomerular dos diversos grupos de estudo aos 300 dias de vida, observamos que os animais do grupo $\mathrm{L}_{\text {Lact }}+\mathrm{V}$ apresentaram notável GS quando comparados aos animais do grupo C, e que a terapia dupla $\mathrm{L}+\mathrm{H}$ foi eficaz em reduzir a progressão desta, conforme exemplificado na Figura 10. A quantificação das lesões glomerulares observadas está representada na Figura 11.
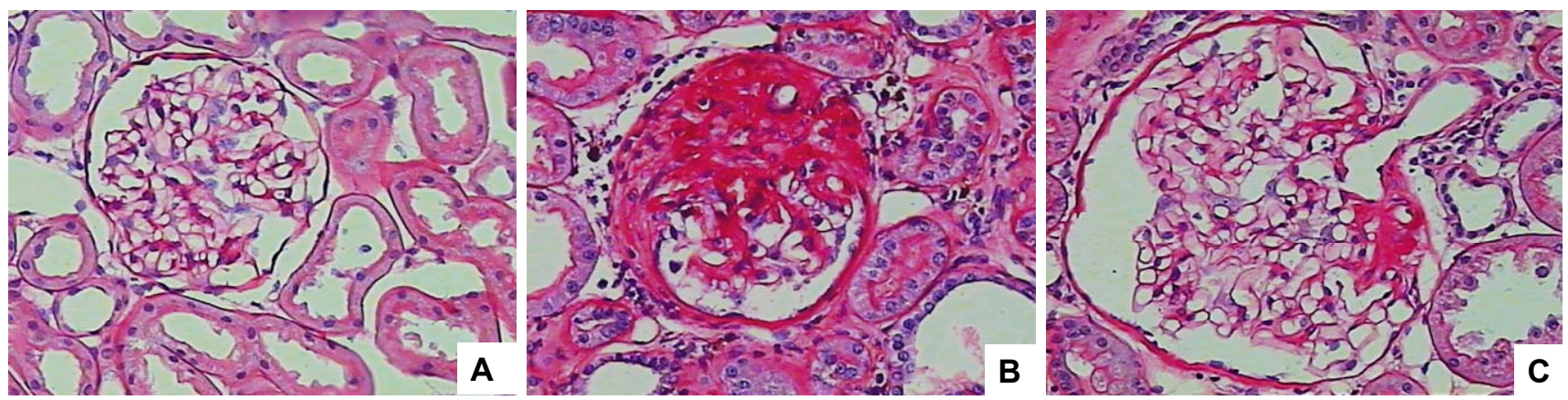

Fig.10: Cortes histológicos de tecido renal, coloração PAS (200X)
A: Grupo $C ;$
; B: Grupo $L_{\text {Lact }}+V ;$
C: Grupo $L_{\text {Lact }}+\mathrm{LH}$

Conforme exposto anteriormente, os animais do grupo $\mathrm{L}_{\text {Lact }}+\mathrm{V}$ apresentaram GS acentuada quando comparados aos animais do grupo C $(100 \pm 27$ vs. $5 \pm 2$, respectivamente, $\mathrm{p}<0,05)$. A monoterapia com $\mathrm{H}$ atenuou apenas modestamente a esclerose glomerular do grupo $\mathrm{L}_{\text {Lact }}+\mathrm{H}(57 \pm 13)$.

Somente os tratamentos que empregaram $L$ (monoterapia e associação $L+H$ ) foram capazes de impedir completamente a progressão da esclerose glomerular, mantendo os índices de GS dos grupos $\mathrm{L}_{\text {Lact }}+\mathrm{L}$ e $\mathrm{L}_{\text {Lact }}+\mathrm{LH}$ em valores semelhantes àqueles observados no grupo $\mathrm{C}$ e até 
mesmo numericamente inferiores àqueles observados no grupo prétratamento, conforme observado na Figura 11.

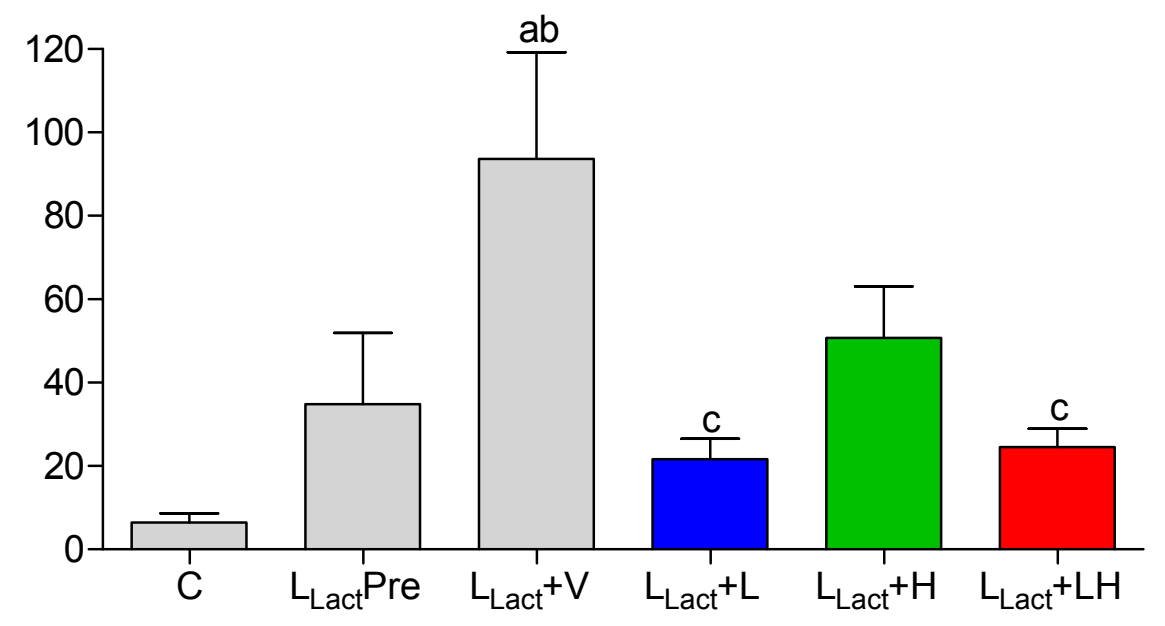

Fig.11: Esclerose glomerular aos 300 dias de vida

a: $p<0,05$ vs. $C, \mathbf{b}: p<0,05$ vs. $L_{\text {Lact }} P r e, c: L_{\text {Lact }}+V, d: L_{\text {Lact }}+L, e: p<0,05$ vs. $L_{\text {Lact }}+H$ 


\section{EXPANSÃO INTERSTICIAL}

Aos 300 dias de vida os animais do grupo $\mathrm{L}_{\text {Lact }}+\mathrm{V}$ apresentavam marcada expansão intersticial quando comparados aos animais do grupo C. $O$ tratamento combinado $L+H$ não foi eficaz na contenção da progressão dessa expansão, conforme o exemplo da Figura 12. A quantificação dos referidos achados histológicos está representada na Figura 13.
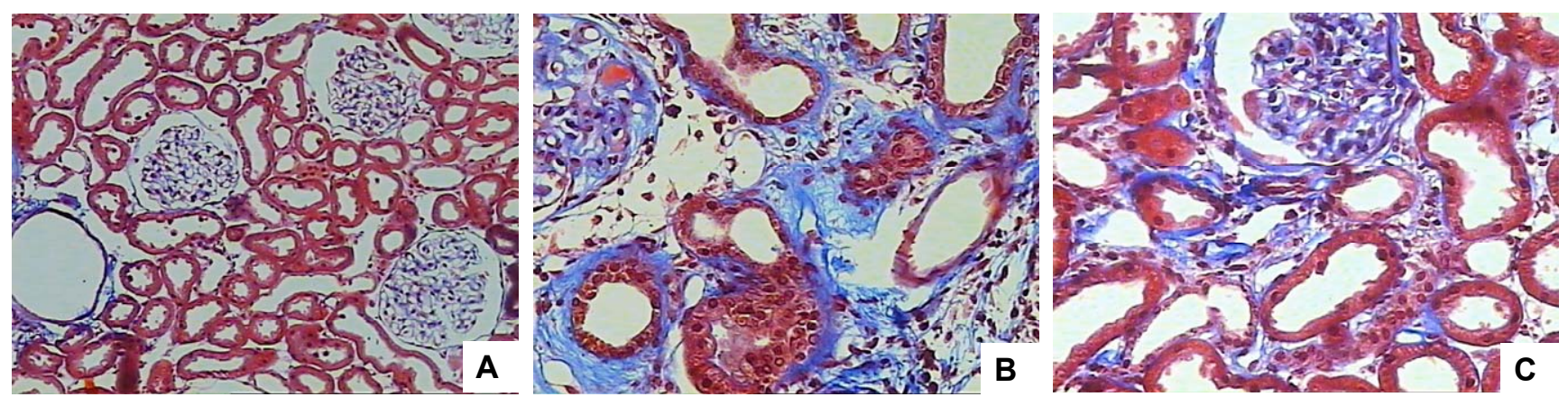

Fig.12: Cortes histológicos de tecido renal, coloração Tricrômio de Massom (200X)
A: Grupo C;
; B: Grupo $L_{\text {Lact }}+V ;$
C: Grupo $\mathrm{L}_{\mathrm{Lact}}+\mathrm{LH}$

Conforme exposto anteriormente, os animais do grupo $\mathrm{L}_{\mathrm{Lact}}+\mathrm{V}$ apresentaram alta percentagem de expansão intersticial quando comparados aos animais do grupo C $(6,0 \pm 0,9 \%$ vs. $0,4 \pm 0,1$, respectivamente, $p<0,05)$. Nenhum dos tratamentos empregados atenuou significativamente a expansão intersticial observada. No entanto nota-se nos grupos tratados com $L\left(L_{\text {Lact }}+L\right.$ e $\left.L_{\text {Lact }}+L H\right)$ certa tendência a uma progressão mais lenta, uma vez que não houve diferença estatística entre esses grupos e o grupo pré-tratamento. 


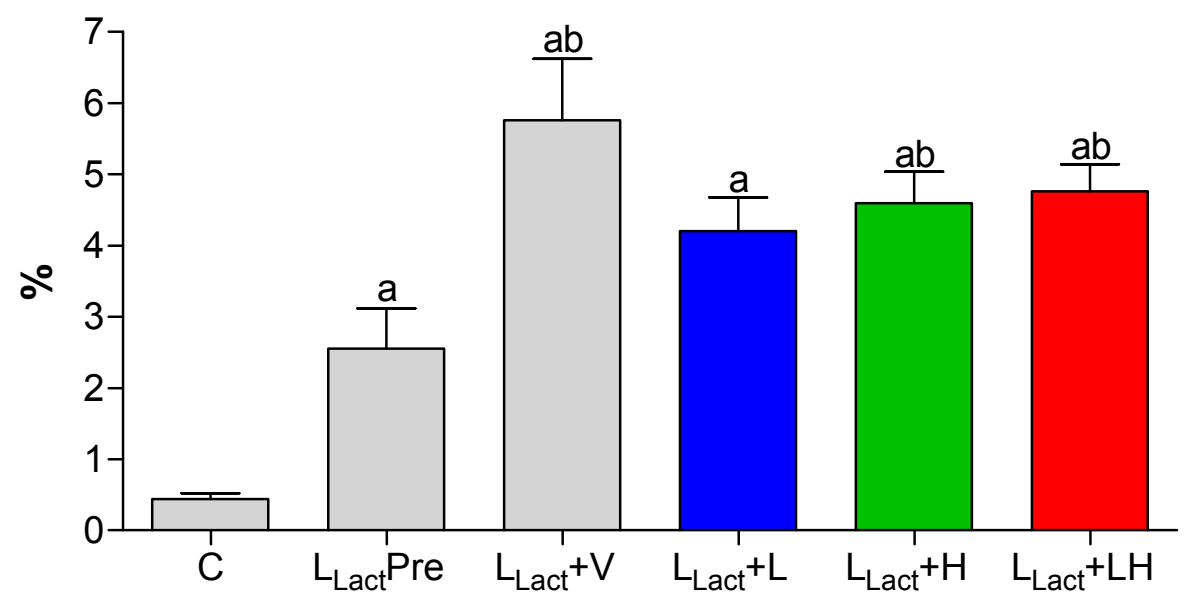

Fig.13: Expansão intersticial aos 300 dias de vida

a: $p<0,05$ vs. $C$, b: $p<0,05$ vs. $L_{\text {Lact }} P r e, c: L_{\text {Lact }}+V, d: L_{\text {Lact }}+L, e: p<0,05$ vs. $L_{\text {Lact }}+H$ 


\section{DISTRIBUIÇÃO DE PERFIS TUBULARES NO CÓRTEX RENAL}

Aos 210 dias de vida, os animais submetidos ao bloqueio do SRAA durante a lactação já apresentavam um número significativamente diminuído de perfis tubulares quantificados por área cortical quando comparados aos animais do grupo controle. Aos 300 dias de vida desses animais, tal redução mostrou-se ainda mais evidente ( $L_{L a c t}+V: 220 \pm 10$ vs. C: $\left.341 \cdot 9, p<0,05\right)$. Essa redução do número de túbulos por unidade de área cortical se dá provavelmente devido a acentuada expansão intersticial observada, associada a uma dilatação tubular decorrente da própria lesão de base do modelo experimental. Nenhum dos tratamentos empregados surtiu efeito sobre a redução do número de túbulos encontrados por unidade de área cortical renal, como representado na Figura 14.

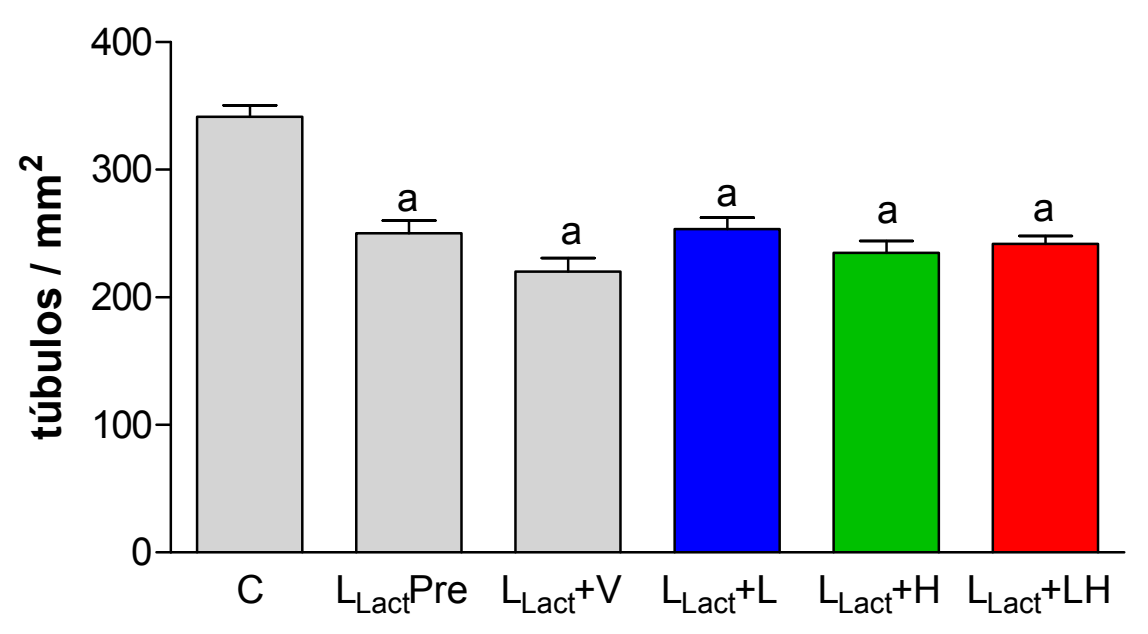

Fig.14: Distribuição de perfis tubulares no córtex renal aos 300 dias de vida a: $p<0,05$ vs. $C, \mathbf{b}: p<0,05$ vs. $L_{L a c t} P r e, c: L_{L a c t}+V, d: L_{L a c t}+L, e: p<0,05$ vs. $L_{L a c t}+H$ 
IMUNO-HISTOQUÍMICA

\section{INFILTRAÇÃO MACROFÁGICA INTERSTICIAL}

Pode-se observar nas Figuras 15 e 16 que os animais do grupo $\mathrm{L}_{\text {Lact }}+\mathrm{V}$ apresentaram acentuada infiltração macrofágica no interstício renal comparados aos do grupo C $\left(167 \pm 20\right.$ vs. $28 \pm 3$ céls $/ \mathrm{mm}^{2}$, respectivamente, $p<0,05)$. Nenhuma das estratégias terapêuticas empregadas foi eficaz em reduzir significativamente esse parâmetro.
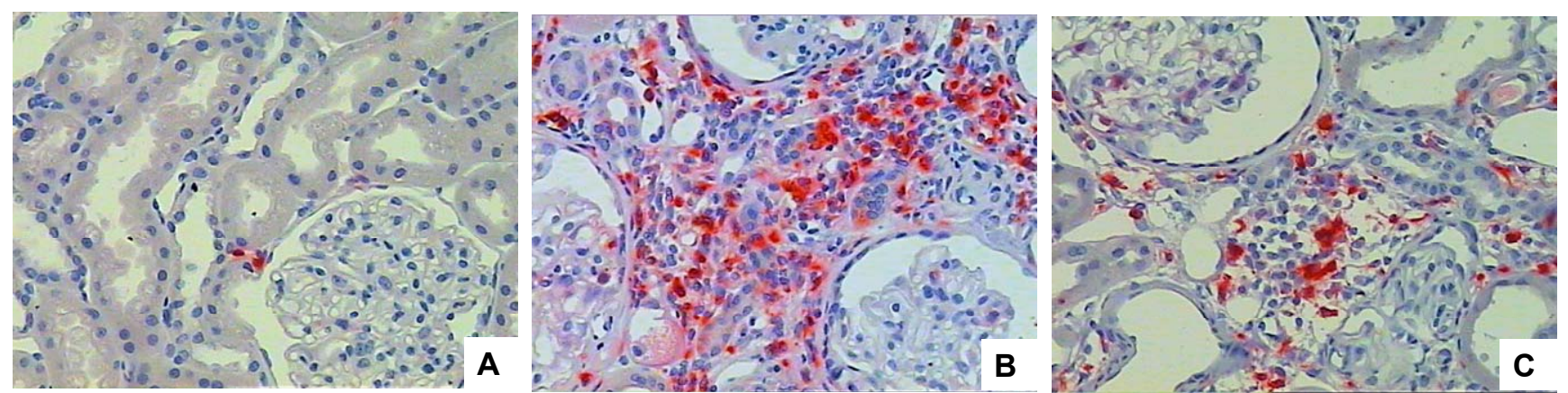

Fig.15: Imuno-histoquímica para macrófagos (200X)

A: Grupo C; B: Grupo $L_{\text {Lact }}+V ;$ C: Grupo $L_{\text {Lact }}+L H$

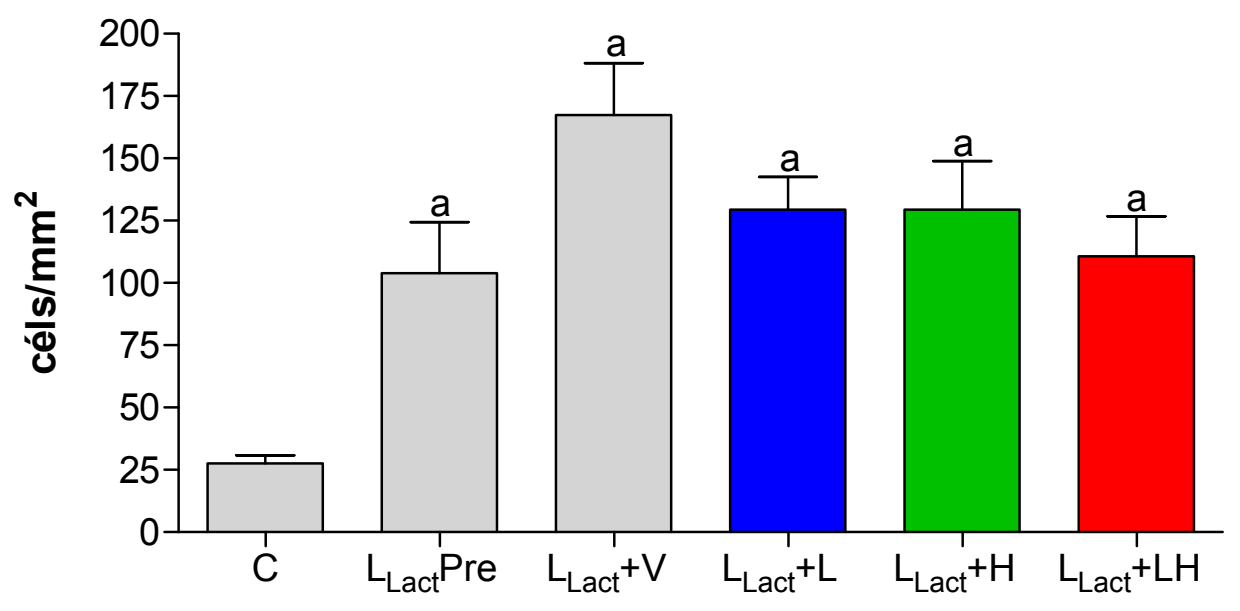

Fig.16: Infiltração Macrofágica Intersticial aos 300 dias de vida

a: $p<0,05$ vs. $C$, b: $p<0,05$ vs. $L_{\text {Lact }} P r e, c: L_{\text {Lact }}+V, d: L_{\text {Lact }}+L, e: p<0,05$ vs. $L_{\text {Lact }}+H$ 


\section{INFILTRAÇÃO LINFOCITÁRIA INTERSTICIAL}

Pode-se observar nas Figuras 17 e 18 que os animais do grupo $L_{\text {Lact }}+V$ apresentaram acentuada infiltração linfocitária intersticial em relação aos animais do grupo $C\left(107 \pm 8\right.$ e $54 \pm 7$ céls $/ \mathrm{mm}^{2}$, respectivamente, $\left.p<0,05\right)$. Nenhuma das estratégias terapêuticas empregadas foi eficaz em reduzir significativamente esse parâmetro.
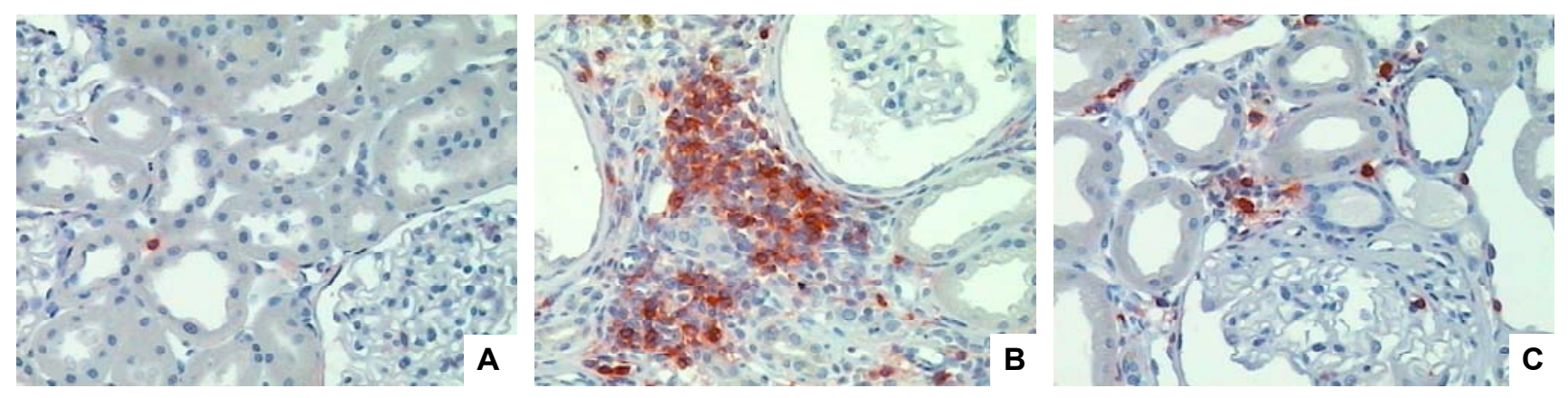

Fig.17: Imuno-histoquímica para linfócitos (200X)

A: Grupo C; B: Grupo $L_{\text {Lact }}+V$; C: Grupo $L_{\text {Lact }}+L H$

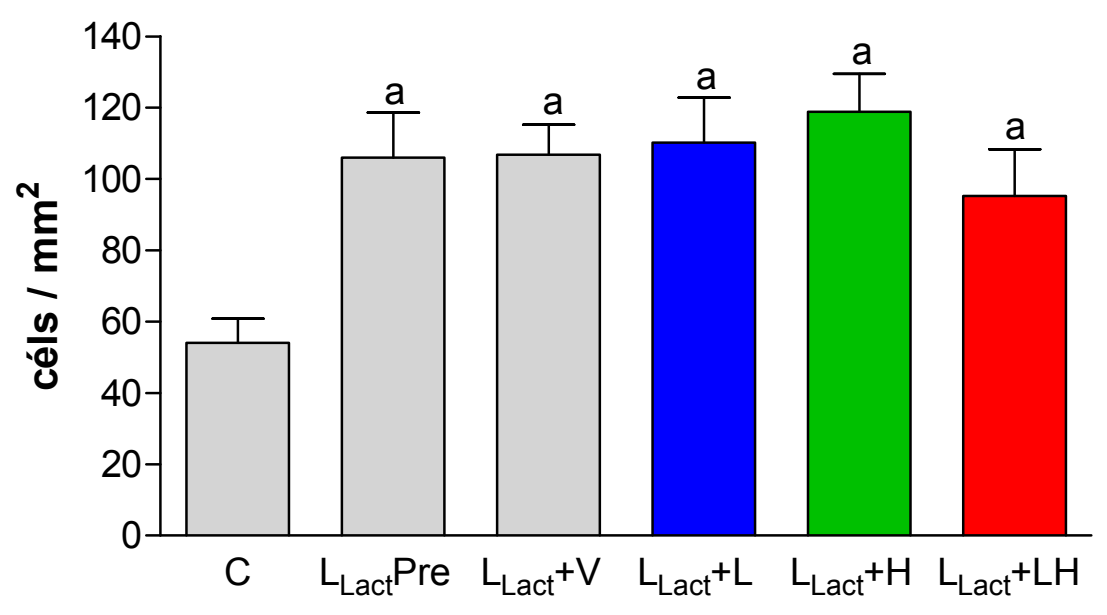

Fig.18: Infiltração Linfocitária Intersticial aos $\mathbf{3 0 0}$ dias de vida a: $p<0,05$ vs. $C$, b: $p<0,05$ vs. $L_{\text {Lact }} P r e, c: L_{\text {Lact }}+V, d: L_{\text {Lact }}+L, e: p<0,05$ vs. $L_{\text {Lact }}+H$ 


\section{NGIOTENSINA II INTERSTICIAL}

Nas Figuras 19 e 20 podemos observar que os animais do grupo $\mathrm{L}_{\text {Lact }}+\mathrm{V}$ apresentaram alta densidade de células intersticiais positivas para All, quando comparados aos animais do grupo C (20 \pm 3 vs. $5 \pm 1$ céls $/ \mathrm{mm}^{2}$, respectivamente, $p<0,05)$. A monoterapia com $L$ reduziu significativamente a densidade dessas células, enquanto a dupla terapia mostrou-se menos eficaz para o controle deste parâmetro.
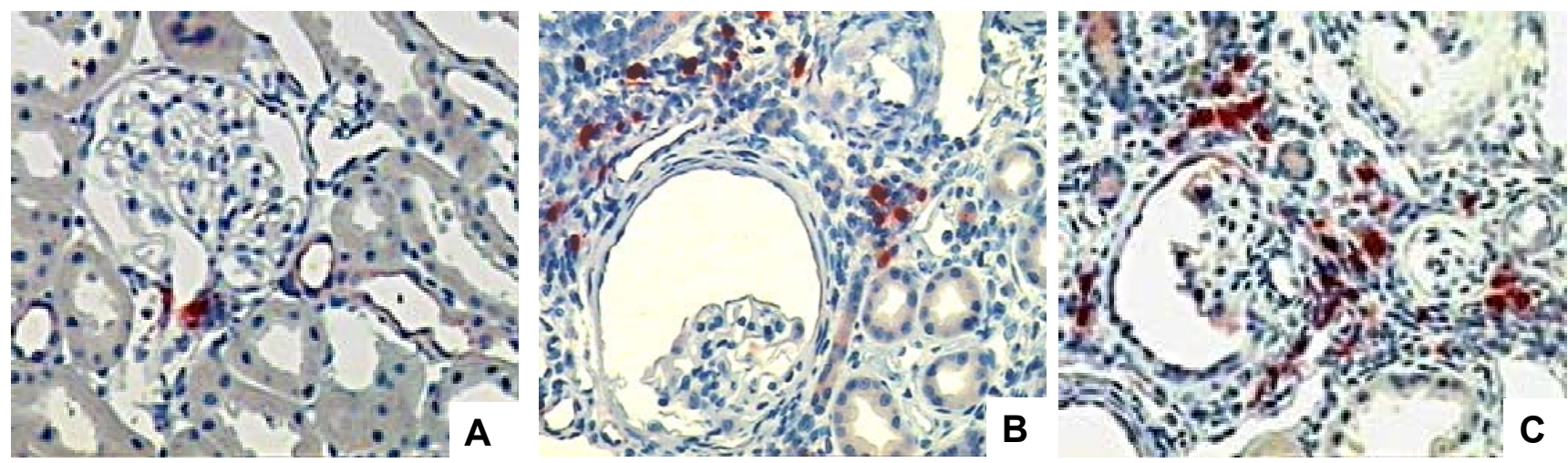

Fig.19: Imuno-histoquímica para células positivas para Angiotensina II (200X)

A: Grupo C; B: Grupo $L_{\text {Lact }}+V$; C: Grupo $L_{\text {Lact }}+L H$

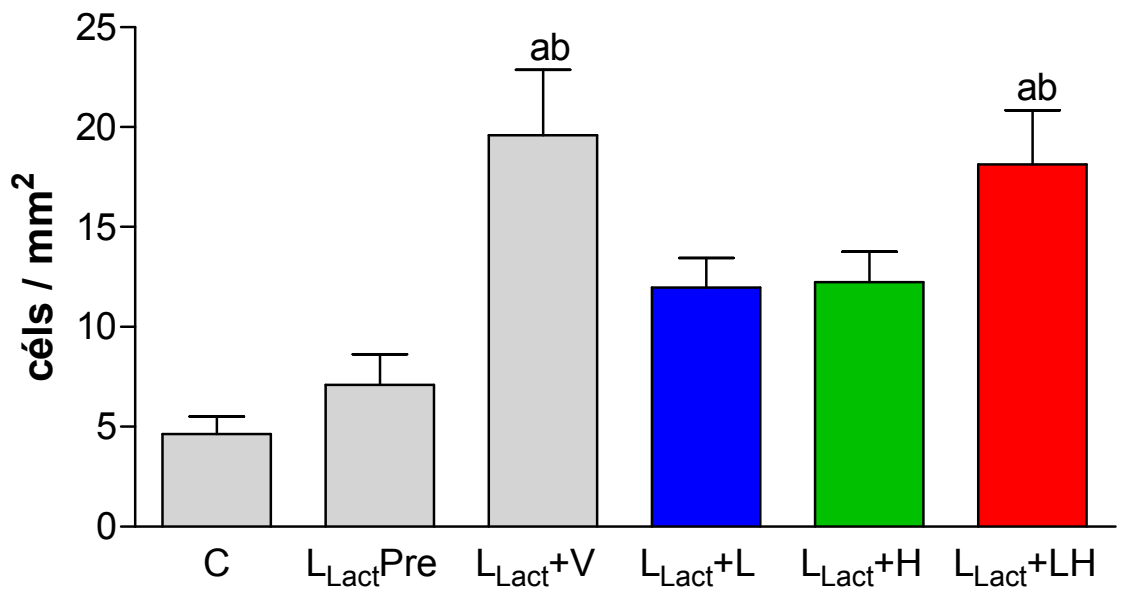

Fig.20: Células intersticiais positivas para All aos 300 dias de vida

a: $p<0,05$ vs. $C, \mathbf{b}: p<0,05$ vs. $L_{\text {Lact }} P r e, c: L_{\text {Lact }}+V, d: L_{\text {Lact }}+L, e: p<0,05$ vs. $L_{\text {Lact }}+H$ 


\section{$\underline{\alpha-A C T I N A ~ I N T E R S T I C I A L}$}

Nas Figuras 21 e 22 podemos verificar que a fração do interstício cortical ocupada por $\alpha$-actina aumentou acentuadamente nos animais do grupo $L_{\text {Lact }}+V(4,1 \pm 0,6 \%$ vs. $0,5 \pm 0,1$ no Grupo $C, p<0,05)$, sugerindo a presença de miofibroblastos nesse compartimento. Dentre os tratamentos testados, a dupla terapia com $\mathrm{L}+\mathrm{H}$ mostrou-se o mais eficaz em reduzir a presença de miofibroblastos no interstício renal, embora não tenha atingido os níveis de $\alpha$-actina apresentados pelo grupo $\mathrm{C}$.
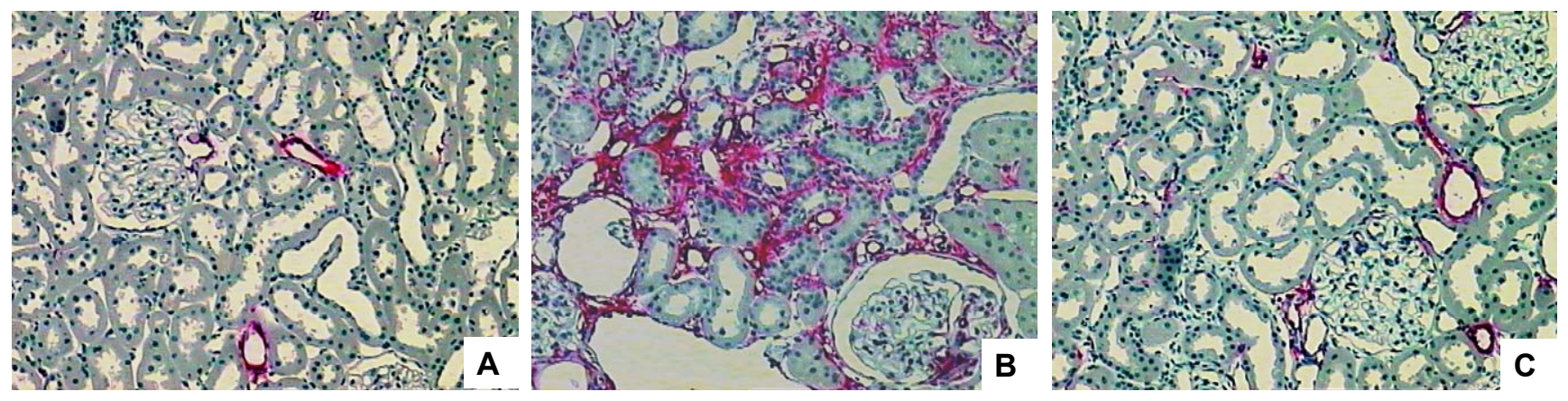

Fig.21 - Imuno-histoquímica para $\alpha$-actina (200X)

A: Grupo C+V; B: Grupo $L_{\text {Lact }}+V ;$ C: Grupo $L_{\text {Lact }}+L H$

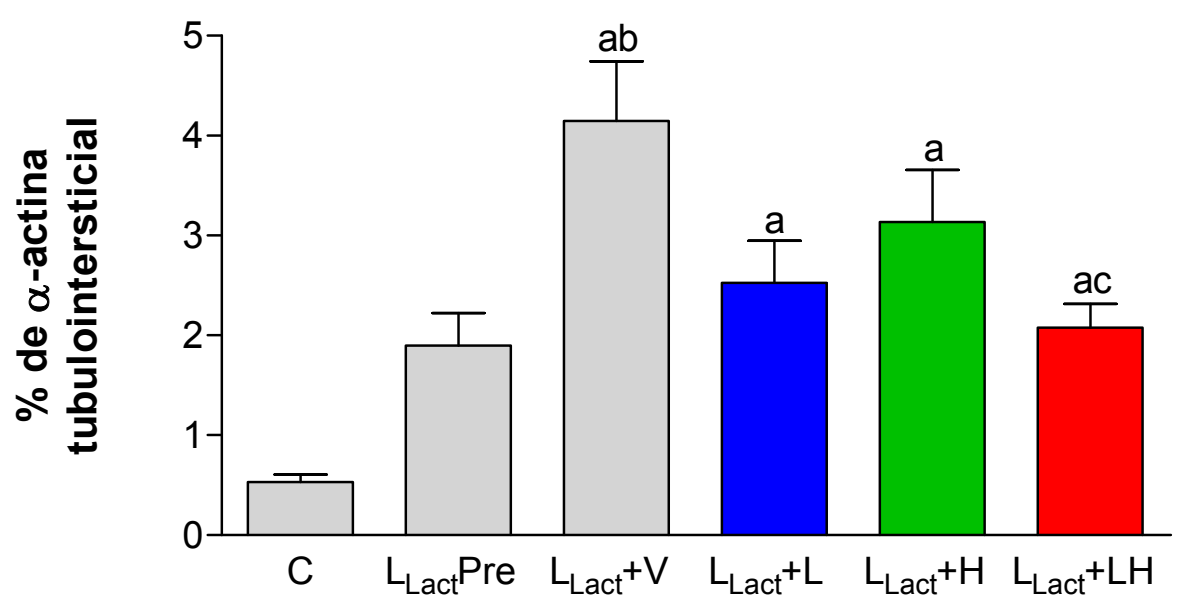

Fig.22: Percentagem de interstício ocupado por $\alpha$-actina aos $\mathbf{3 0 0}$ dias de vida a: $p<0,05$ vs. $C, \mathbf{b}: p<0,05$ vs. $L_{\text {Lact }} P r e, c: L_{L a c t}+V, d: L_{L a c t}+L, e: p<0,05$ vs. $L_{L a c t}+H$ 


\section{PROLIFERAÇÃO CELULAR}

Proliferação de células intersticiais

Nas Figuras 23 e 24 verificamos um aumento significativo de células em proliferação no interstício renal $\left(107 \pm 12\right.$ vs. $20 \pm 3$ céls $/ \mathrm{mm}^{2}$, respectivamente, $p<0,05)$ dos animais do grupo $L_{\text {Lact }}+V$ em relação ao grupo C. O tratamento com $\mathrm{L}+\mathrm{H}$ reduziu a taxa de proliferação celular intersticial
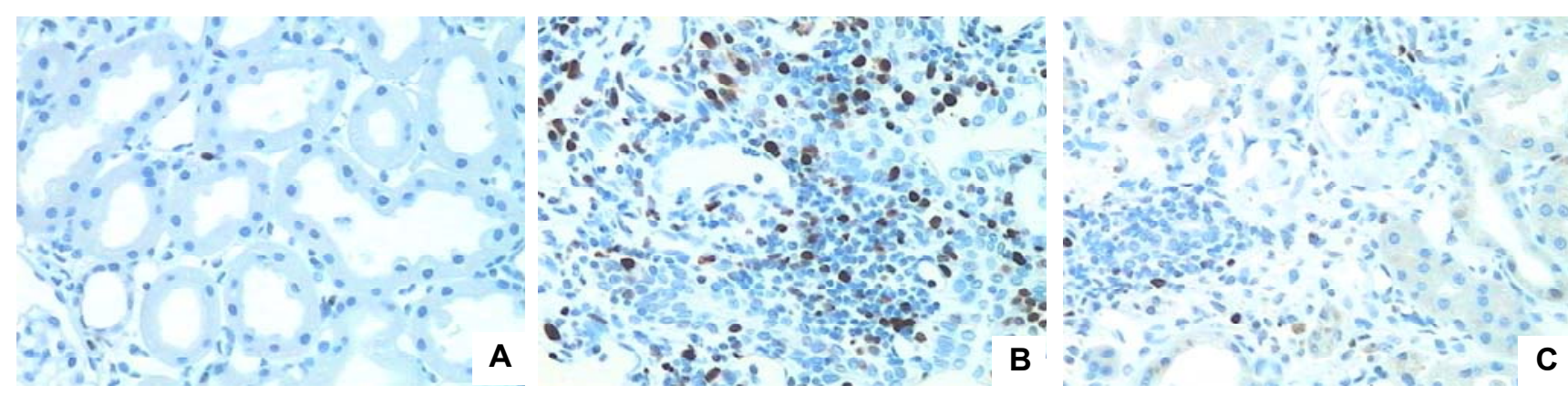

Fig.23 - Imuno-histoquímica para PCNA (antígeno de proliferação tubular) no interstício renal (200X)

A: Grupo C; B: Grupo $L_{\text {Lact }}+V$; C: Grupo $L_{\text {Lact }}+L H$

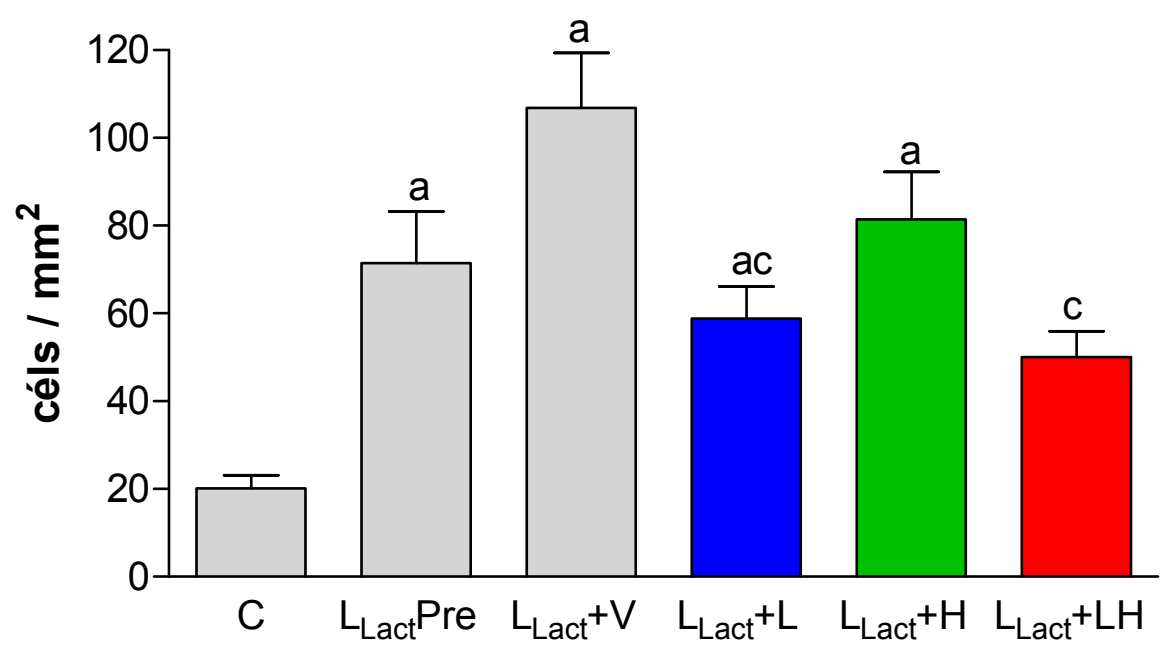

Fig.24: Proliferação de células intersticiais aos $\mathbf{3 0 0}$ dias de vida a: $p<0,05$ vs. $C, \mathbf{b}: p<0,05$ vs. $L_{\text {Lact }} P r e, c: L_{\text {Lact }}+V, d: L_{\text {Lact }}+L$, e: $p<0,05$ vs. $L_{\text {Lact }}+H$ 
Proliferação de células tubulares

$\mathrm{Na}$ Figura 25 observamos um aumento do número de células tubulares em proliferação no parênquima renal dos animais $L_{L a c t}+V$ quando comparados aos animais do grupo C.

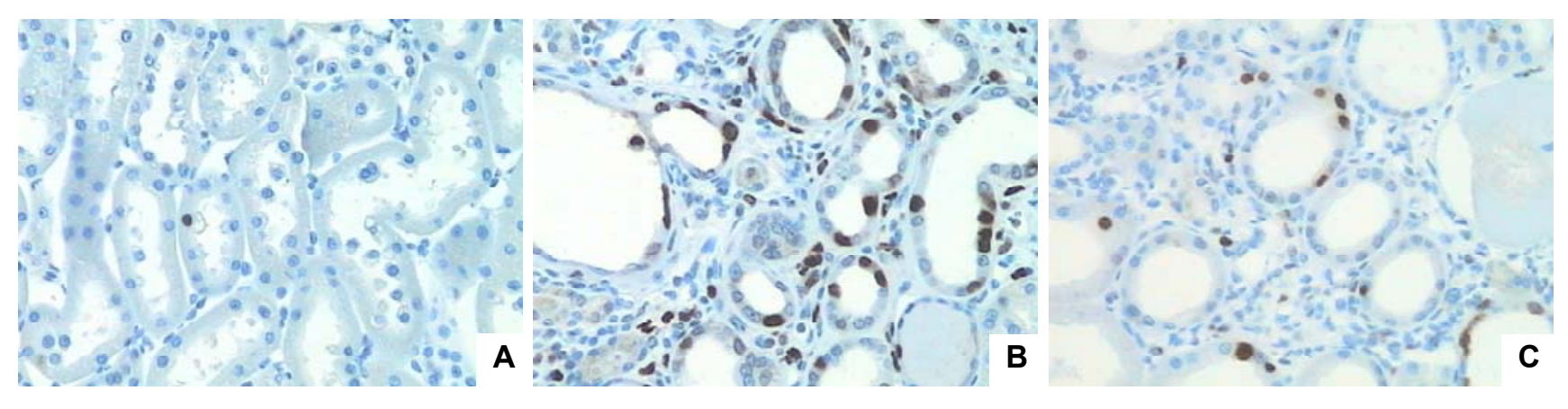

Fig.25 - Imuno-histoquímica para PCNA nas células tubulares renais (200X)
A: Grupo C:
B: Grupo L Lact $+V$;
C: Grupo $\mathrm{L}_{\mathrm{Lact}}+\mathrm{LH}$

A quantificação das células em proliferação presentes no compartimento tubular do córtex renal foi realizada através da contagem do número de células tubulares positivas para o marcador PCNA por perfil tubular cortical. Podemos observar os dados obtidos na Figura 26.

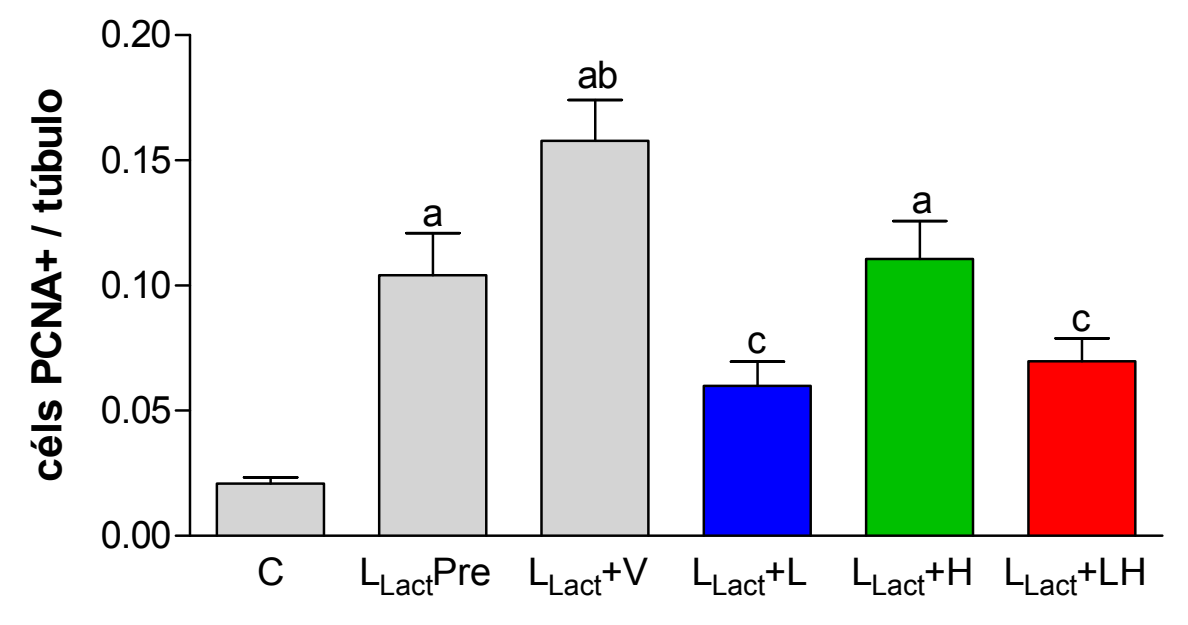

Fig.26: Células PCNA+ por perfil tubular cortical aos 300 dias de vida.

a: $p<0,05$ vs. $C, \mathbf{b}: p<0,05$ vs. $L_{L a c} P r e, c: L_{L a c t}+V, d: L_{L a c t}+L, e: p<0,05$ vs. $L_{L a c t}+H$ 
Aos 210 dias de vida, os animais submetidos ao bloqueio do SRAA durante a lactação já apresentavam um número significativamente aumentado de células tubulares em proliferação quando comparados aos animais do grupo C. Com o passar do tempo, esse aumento tornou-se ainda mais marcante. $\left(0,16 \pm 0,016\right.$ cél $/ \mathrm{mm}^{2}$ no grupo $L_{\text {Lact }}+V$ vs. $0,02 \pm 0,003$ cél $/ \mathrm{mm}^{2}$ no grupo $C$ ). Tanto a monoterapia com $L$, quanto a associação $L+H$ foram eficazes em reduzir a proliferação das células tubulares, fazendo com que esta atingisse valores compatíveis com aqueles observados nos animais controles nos grupos $L_{\text {Lact }}+\mathrm{L}$ e $L_{\text {Lact }}+\mathrm{LH}$. 


\section{ANÁLISES DE CORRELAÇÃO ENTRE OS PRINCIPAIS MARCADORES}

\section{INFLAMATÓRIOS AOS 300 DIAS DE VIDA}

Foram realizadas análises de correlação entre; percentagem de expansão intersticial e expressão de $\alpha$-actina de músculo liso no compartimento tubulointersticial (Figura 27), percentagem de expansão intersticial e proliferação tubular intersticial (Figura 28) e expressão de $\alpha$ actina de músculo liso e proliferação celular intersticial (Figura 29). Os gráficos de regressão linear indicaram a existência de correlação positiva significativa em todas as análises.

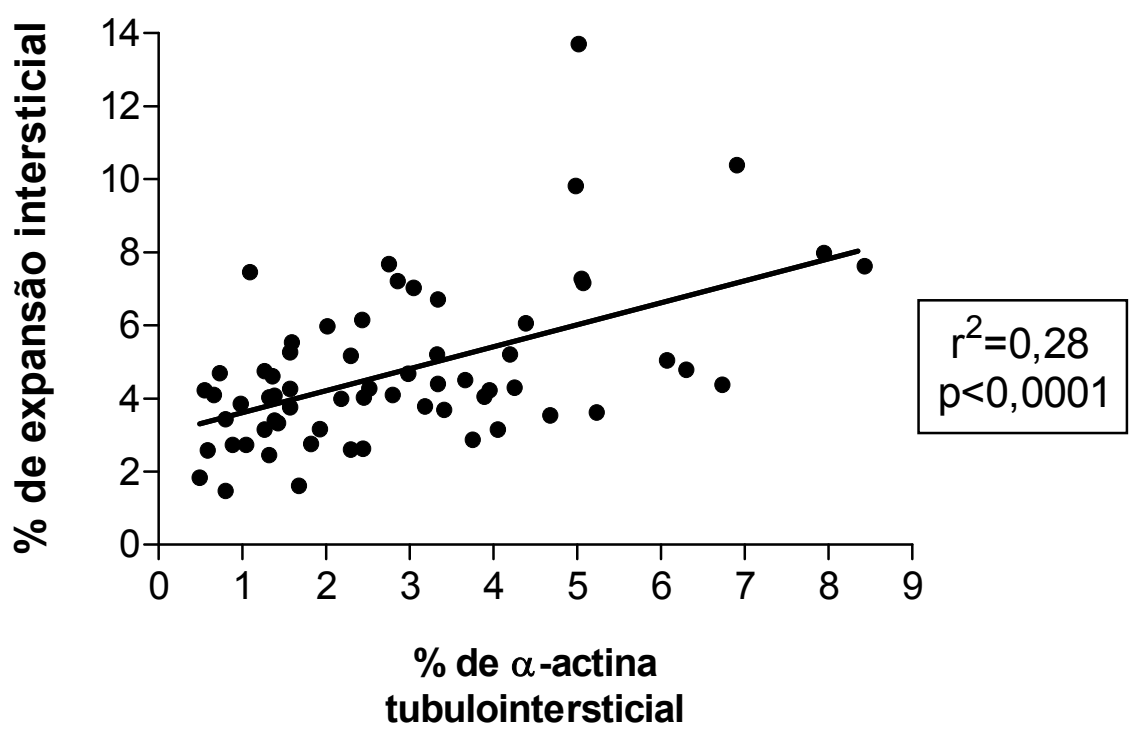

Fig.27: Correlação positiva entre a percentagem de expansão intersticial e a percentagem de $\alpha$-actina de músculo liso no compartimento tubulointersticial Foram incluidos neste gráfico os animais dos grupos: $L_{\text {Lact }}+V, L_{\text {Lact }}+L, L_{\text {Lact }}+H$ e $L_{L \text { act }}+L H$ 


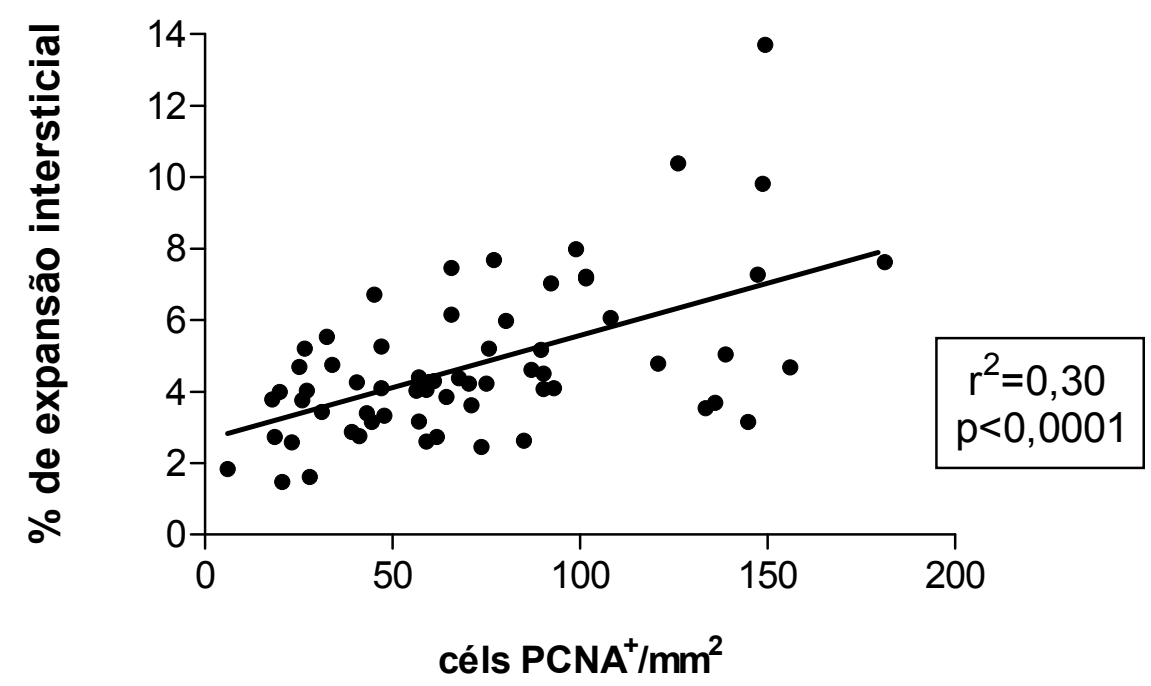

Fig.28: Correlação positiva entre a percentagem de expansão intersticial e a proliferação celular intersticial

Foram incluídos neste gráfico os animais dos grupos: $L_{\text {Lact }}+V, L_{\text {Lact }}+L, L_{\text {Lact }}+H$ e $L_{\text {Lact }}+L H$

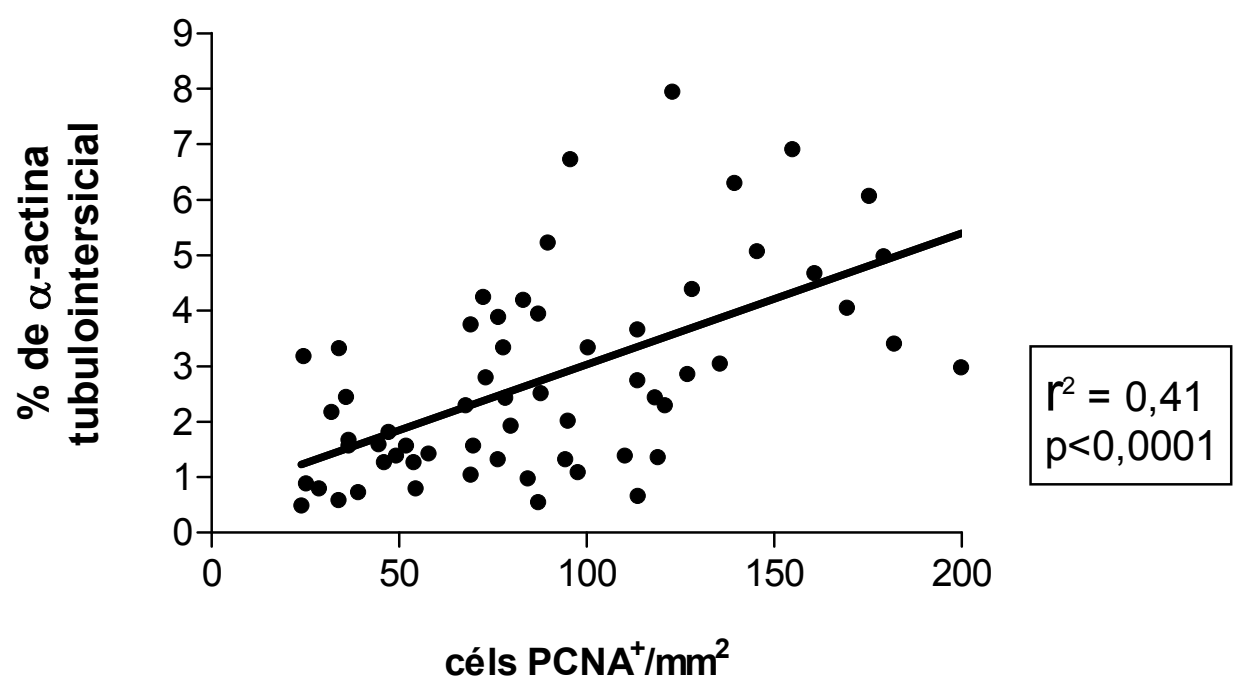

Fig.29: Correlação positiva entre a percentagem de $\alpha$-actina de músculo liso no compartimento tubulointersticial e a proliferação celular intersticial Foram incluídos neste gráfico os animais dos grupos: $L_{\text {Lact }}+V, L_{\text {Lact }}+L, L_{\text {Lact }}+H$ e $L_{\text {Lact }}+L H$ 


\section{QUANTIFICAC̨ÃO DE VASOS SANGUÍNEOS NO PARÊNQUIMA RENAL}

Vasos peritubulares

Nas Figuras 30 e 31 verificamos uma redução numérica do número total de vasos sanguíneos por $\mathrm{mm}^{2}$ no compartimento peritubular dos animais do grupo $\mathrm{L}_{\text {Lact }}+\mathrm{V}$ em relação ao grupo $\mathrm{C}(537 \pm 45$ vs. $626 \pm 20$ vasos $/ \mathrm{mm}^{2}$, respectivamente). Nenhum dos tratamentos utilizados alterou este parâmetro.
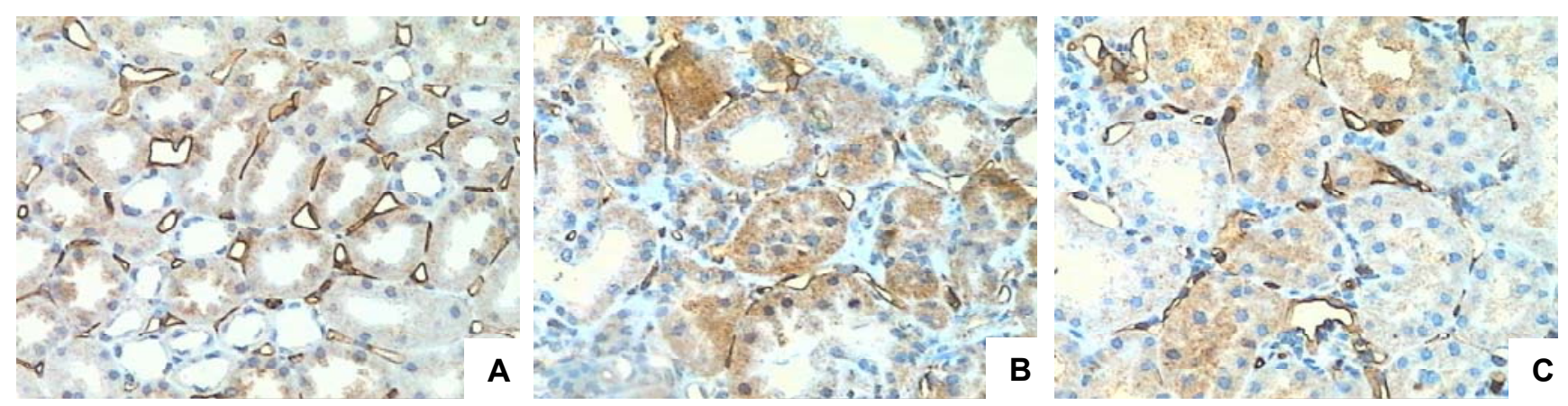

Fig.30 - Imuno-histoquímica para JG12 (Aminopeptidase-P, marcador endotelial) no espaço peritubular renal aos 300 dias de vida (200X)
A: Grupo C;
B: Grupo $L_{\text {Lact }}+V$;
C: Grupo $L_{\text {Lact }}+\mathrm{LH}$

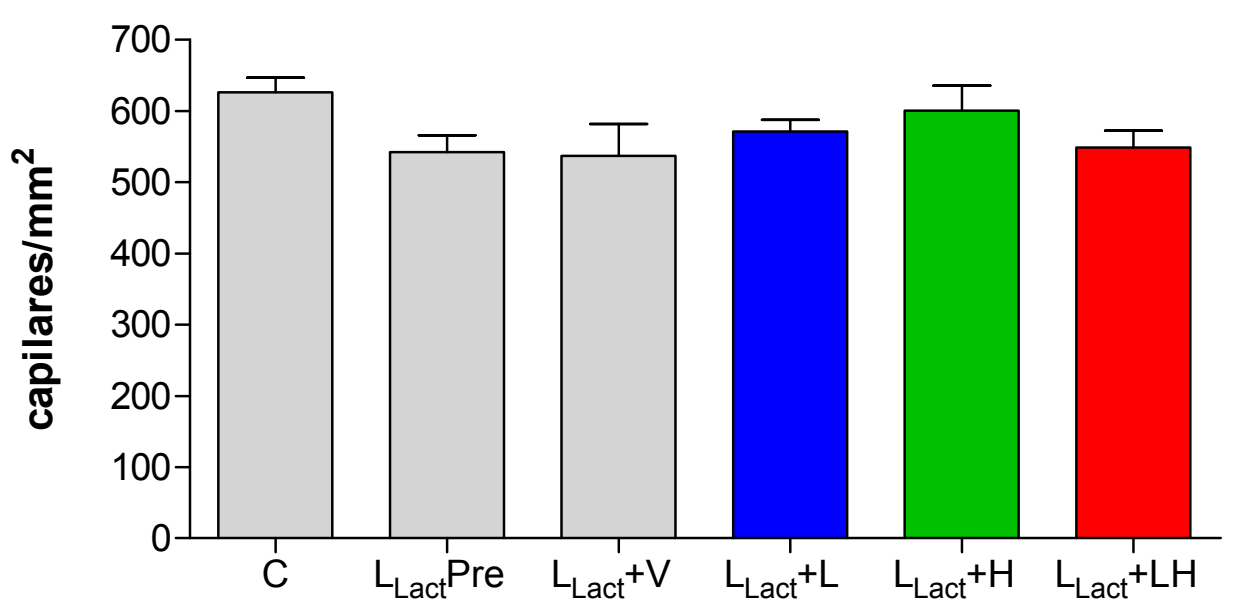

Fig.31: Capilares peritubulares por área cortical renal aos $\mathbf{3 0 0}$ dias de vida a: $p<0,05$ vs. $C, \mathbf{b}: p<0,05$ vs. $L_{\text {Lact }} P r e, c: L_{\text {Lact }}+V, d: L_{\text {Lact }}+L, e: p<0,05$ vs. $L_{\text {Lact }}+H$ 
Com o objetivo de evitar uma subestimação do número de capilares peritubulares devido ao aumento da área intersticial ou à dilatação tubular presente nos animais tratados com $L$ durante a lactação, realizou-se uma segunda quantificação do número de capilares peritubulares, desta vez sendo representada pela razão entre: número de capilares peritubulares por campo microscópico sobre o número de perfis tubulares naquele mesmo campo. Essa razão mostrou um aumento do número de capilares por túbulo nos grupos $\mathrm{L}_{\text {Lact }}+\mathrm{V}, \mathrm{L}_{\mathrm{Lact}}+\mathrm{L}$ e $\mathrm{L}_{\text {Lact }}+\mathrm{H}$, provavelmente ocasionado pela redução do numero de túbulos por campo, em resposta à expansão intersticial pronunciada observada nesses animais. (Figura 32).

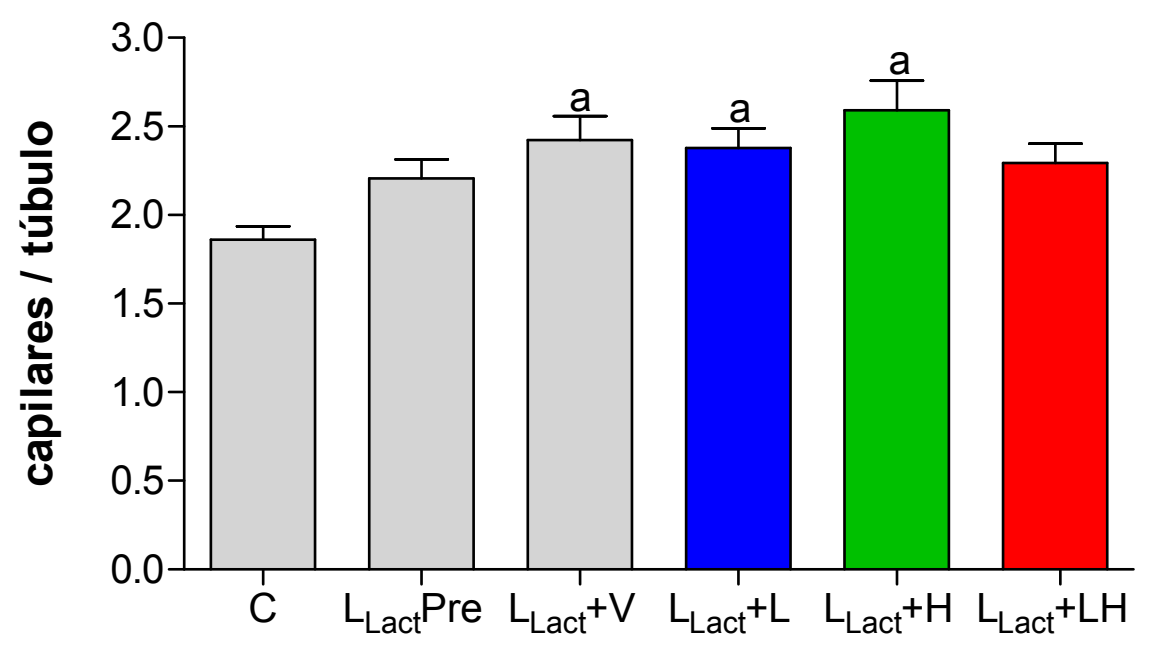

Fig.32: Razão entre capilares peritubulares / túbulos corticais a: $p<0,05$ vs. $C, \mathbf{b}: p<0,05$ vs. $L_{\text {Lact }} P r e, c: L_{L a c t}+V, d: L_{\text {Lact }}+L, e: p<0,05$ vs. $L_{\text {Lact }}+H$ 
Foram realizadas análises de correlação, através de regressão linear, entre a expansão intersticial e o número de capilares peritubulares nos animais submetidos ao bloqueio do SRAA durante a nefrogênese. Como demonstrado na Figura 33, não foi observada correlação entre os parâmetros nos animais $L_{\text {Lact }}$ aos 210 dias de vida.

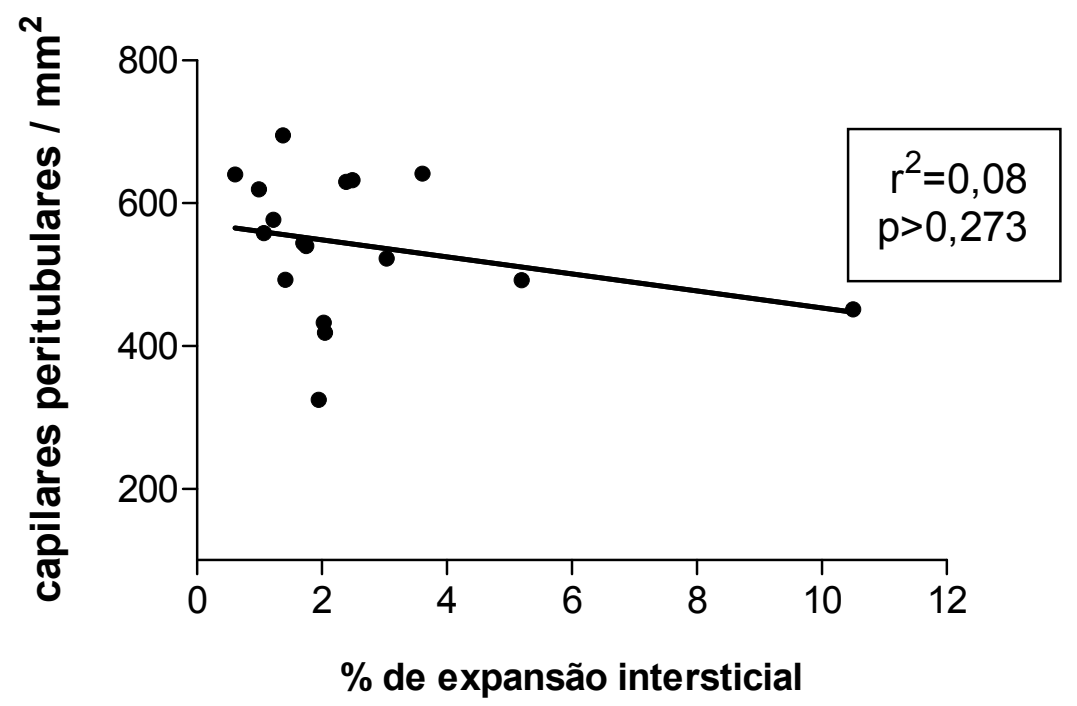

Fig.33: Correlação entre a percentagem de expansão intersticial e o número de capilares peritubulares dos animais $L_{\text {Lact }}$ aos 210 dias de vida Foram incluídos neste gráfico somente os animais do grupo $L_{\text {Lact }} P r e$ 
Aos 300 dias de vida observou-se uma correlação negativa significativa entre a expansão intersticial e o número de capilares peritubulares nos animais LLact (Figura 34).

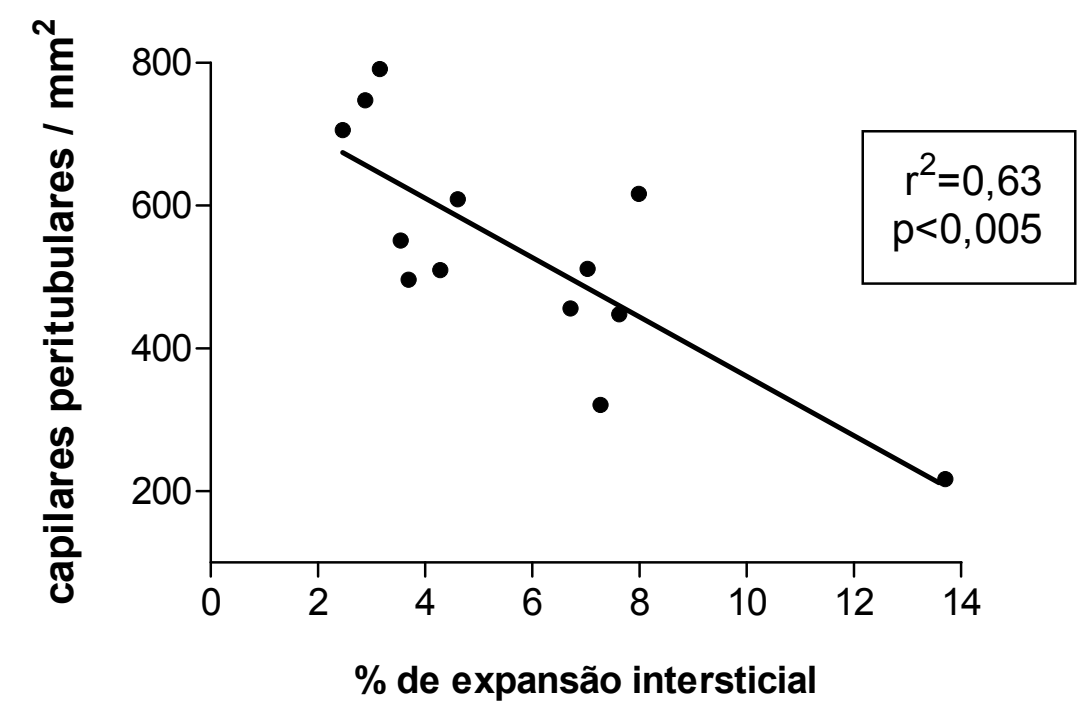

Fig.34: Correlação negativa entre a percentagem de expansão intersticial e o número de capilares peritubulares dos animais $L_{\text {Lact }}$ aos 300 dias de vida Foram incluídos neste gráfico apenas os animais do grupo: $L_{\text {Lact }}+V$ 


\section{Capilares glomerulares}

Nas Figuras 35 e 36 verificamos uma redução numérica da área intraglomerular ocupada por endotélio vascular (JG12) nos animais do grupo $\mathrm{L}_{\text {Lact }}+\mathrm{V}$ em relação ao grupo $\mathrm{C}$.
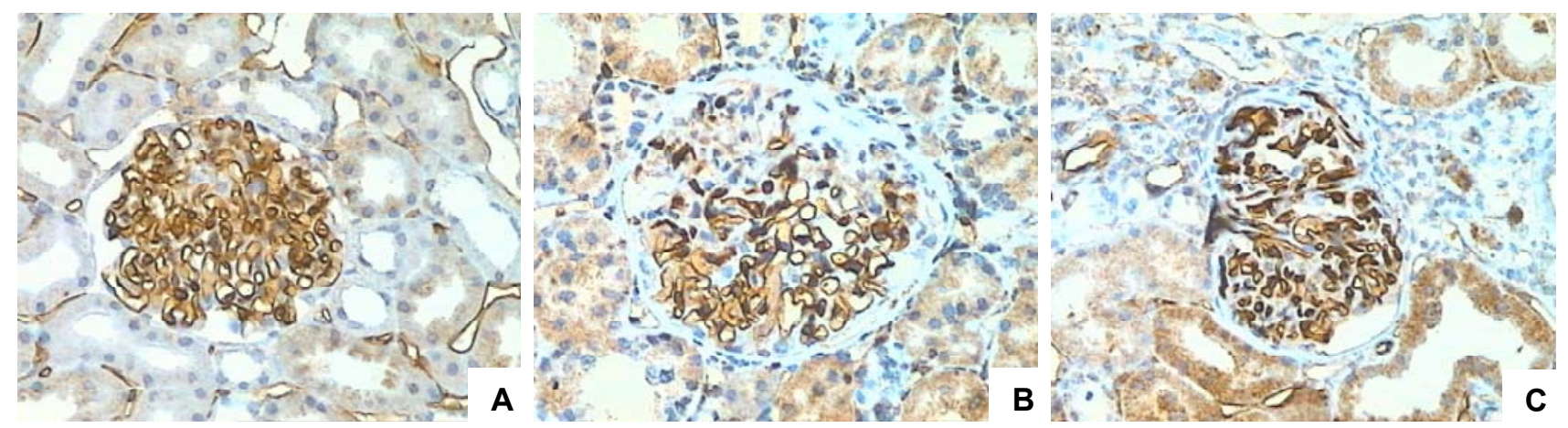

Fig.35 - Imuno-histoquímica para JG12 (Aminopeptidase-P, marcador endotelial) glomerular (200X)

A: Grupo C; B: Grupo $L_{\text {Lact }}+V$; C: Grupo $L_{\text {Lact }}+L H$

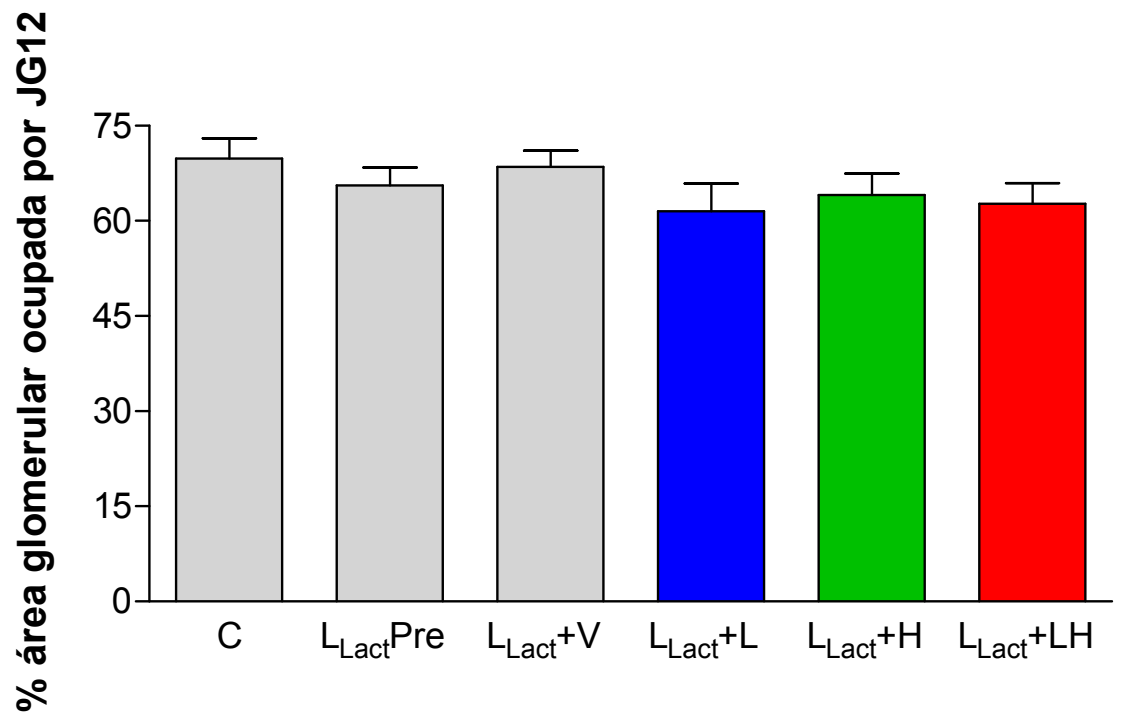

Fig.36: Vasos sanguíneos intraglomerulares aos 300 dias de vida a: $p<0,05$ vs. $C, \mathbf{b}: p<0,05$ vs. $L_{\text {Lact }} P r e, c: L_{\text {Lact }}+V, d: L_{\text {Lact }}+L, e: p<0,05$ vs. $L_{\text {Lact }}+H$ 


\section{METALOPROTEINASES}

A atividade de 2 das principais gelatinases pertencentes à família das metaloproteinases de matriz extracelular, as MMPs 2 e 9, foi avaliada através da técnica de zimografia em gelatina.

A Figura 37 ilustra o padrão de bandas "negativas" produzidas a partir da digestão enzimática do substrato adicionado ao gel de poliacrilamida pelas enzimas estudadas, cujos pesos moleculares são 71 e 92 kDa, respectivamente.

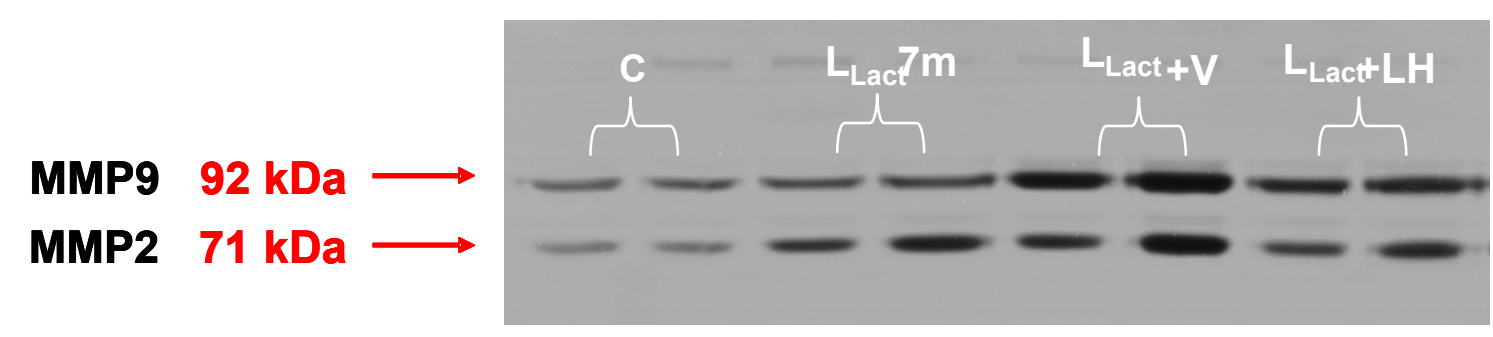

Fig.32: Zimografia em gelatina para detecção de MMP2 e MMP9 
MMP2: Aos 210 dias de vida, a atividade da MMP2 nos animais submetidos à administração de $\mathrm{L}$ durante a lactação não se mostrou aumentada em relação ao grupo C. Com o passar do tempo e o avançar da lesão renal, observamos, aos 300 dias de vida, que a atividade da MMP2 do grupo $\mathrm{L}_{\text {Lact }}+\mathrm{V}$ passou a ser $2,7 \pm 0,4$ vezes superior àquela observada no grupo $\mathrm{C}$ $(p<0,05)$. Nenhum dos tratamentos empregados promoveu uma redução significativa na atividade da MMP2 (Figura 38).

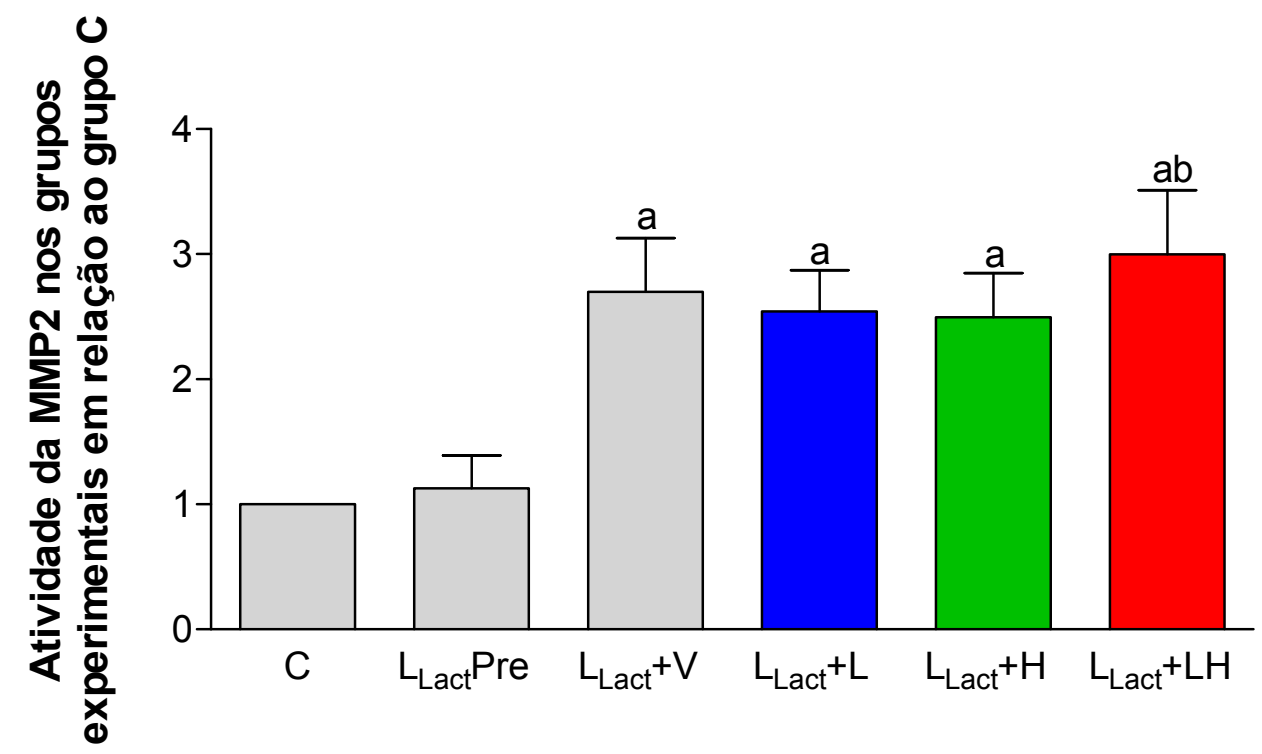

Fig.38: Atividade da Metaloproteinase 2

a: $p<0,05$ vs. $C, \mathbf{b}: p<0,05$ vs. $L_{\text {Lact }} P r e, c: L_{L a c t}+V, d: L_{\text {Lact }}+L, e: p<0,05$ vs. $L_{\text {Lact }}+H$ 
MMP9: A atividade da MMP9 tecidual nos animais submetidos ao bloqueio do receptor AT1 durante a nefrogênese mostrou-se apenas numericamente elevada em comparação com o grupo controle (C), aos 300 dias de vida. As terapias empregadas no estudo não alteraram esse parâmetro (Figura 39).

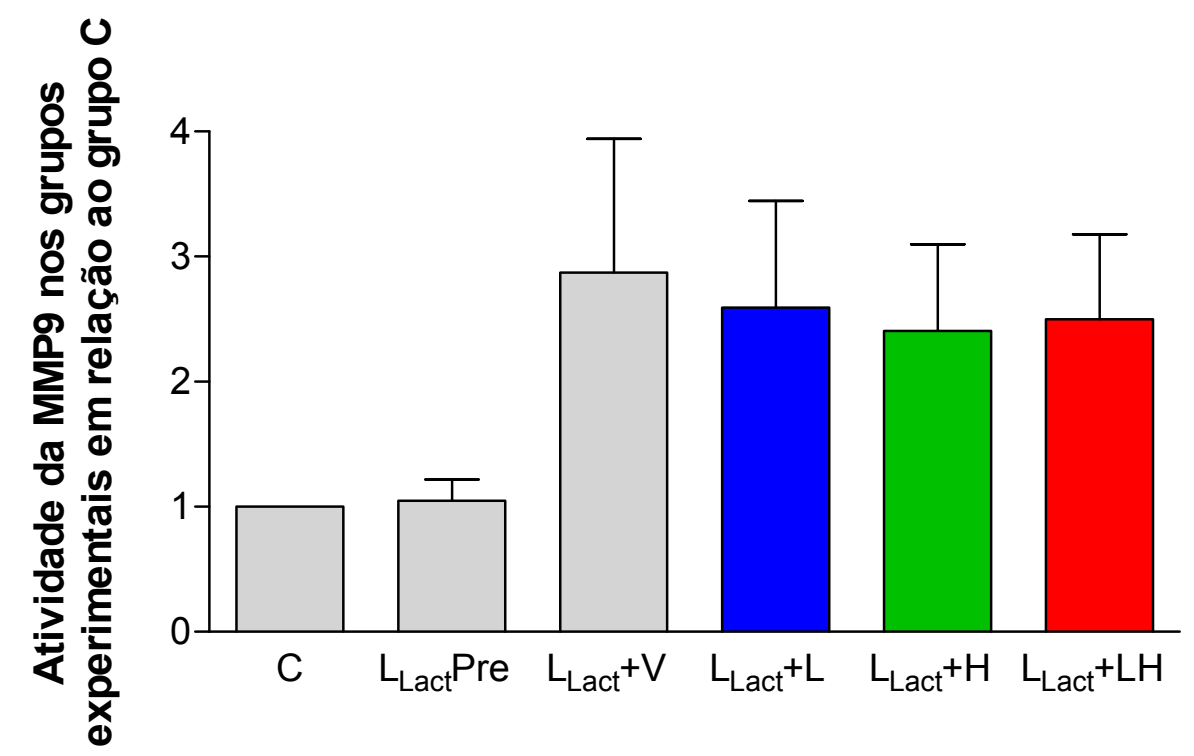

Fig.39: Atividade da Metaloproteinase 9

a: $p<0,05$ vs. $C$, b: $p<0,05$ vs. $L_{\text {Lact }} P r e, c: L_{\text {Lact }}+V, d: L_{\text {Lact }}+L, e: p<0,05$ vs. $L_{\text {Lact }}+H$ 


\section{DISCUSSÃO}

\section{CARACTERIZAÇÃO DO MODELO EXPERIMENTAL}

Corroborando os dados observados em estudos anteriores, os animais submetidos ao bloqueio do SRAA durante a lactação apresentaram taxa de mortalidade inferior a $25 \%$, que pode ser considerada baixa, levando-se em consideração a gravidade da DRC nessa fase.

Aos 210 dias de vida, os animais L Lact já apresentaram uma intensa atrofia medular e papilar, além de incapacidade de concentrar a urina, e conseqüente poliúria. De acordo com Lasaitiene et al, as células da porção espessa ascendente das alças de Henle de animais que sofrem supressão da All durante a nefrogênese apresentam alterações fenotípicas, tais como redução dos transportadores BSC-1 (também chamados de NKCC2), que realizam a reabsorção de sódio, potássio e cloreto. Dessa forma, a tubulopatia primária característica desse modelo experimental faz com que os animais $L_{\text {Lact }}$ se comportem como perdedores de sal, já que a deficiência dos transportadores BSC-1 reduz a reabsorção de sódio nas alças de Henle de maneira semelhante ao efeito da administração de um diurético de alça, como o Furosemide [20]. Sabe-se também que a porção ascendente da alça de Henle é um segmento de extrema importância para o processo de concentração urinária, uma vez que é essencial à formação da hipertonicidade medular, que permite a reabsorção de água nas porções distais do néfron. Essas alterações tubulares poderiam justificar a acentuada poliúria observada nos animais $L_{\text {Lact. }}$ Além disso, a All é reconhecida como um dos fatores que regula o desenvolvimento da pelve renal durante a 
nefrogênese, contribuindo para a correta formação das células marca-passo, responsáveis por iniciar o movimento de peristaltismo ureteral. O bloqueio da All durante esse período pode ter desequilibrado a programação das células musculares lisas da pelve renal, causando acúmulo de fluido nos ureteres e hidronefrose nesses animais.

Apesar de apresentem uma redução de cerca de $30 \%$ no número de néfrons [27], os animais LLact manifestaram hipertensão arterial significativa somente após os 210 dias de vida, ou seja, tardiamente. Esse achado, demonstrado anteriormente neste mesmo Laboratório [27] é bastante surpreendente, uma vez que a relação entre baixo número de néfrons ao nascimento e desenvolvimento de hipertensão na vida adulta é bem estabelecida [38] e pode ser explicada aplicando-se a concepção de Guyton: o número reduzido de néfrons levaria a uma queda da taxa de excreção renal de sódio, desenvolvendo-se uma hipertensão, inicialmente dependente de um aumento do débito cardíaco, que devido ao fenômeno da autoregulação tecidual, passaria a depender de uma elevação permanente da resistência periférica. A elevação da pressão arterial restaura o balanço de sódio através do mecanismo de natriurese pressórica [62].

As razões que atrasam o desenvolvimento de hipertensão arterial neste modelo ainda não foram completamente elucidadas. Uma explicação bastante plausível seria a própria tubulopatia característica do modelo, que faz dos animais $L_{\text {Lact }}$ "perdedores de sal"; ou seja, se por um lado o número reduzido de néfrons favorece a retenção de sódio, por outro o defeito funcional da porção espessa ascendente da alça de Henle restaura a taxa 
de excreção do íon, tornando desnecessária a elevação da PA para manter o balanço de sódio. Com a progressão da DRC e perda gradual de mais e mais néfrons, o defeito tubular não mais consegue compensar a redução da excreção de sódio. Assim, os animais passam a manifestar hipertensão arterial, como observado aos 300 dias de vida, uma vez que a resposta de natriurese pressórica passa a ser essencial à manutenção do balanço de sódio.

Os animais $L_{\text {Lact }}$ apresentaram albuminúria pronunciada, já aos 210 dias de vida. Esta progrediu significativamente, atingindo valores bastante elevados aos 300 dias de vida, corroborando novamente dados obtidos em estudos anteriores [27]. As razões para a quebra da integridade da barreira de filtração glomerular nesse modelo ainda não são claras. Machado et al demonstraram que animais submetidos ao bloqueio da All durante a lactação apresentam uma redução precoce e significativa da expressão da proteína zonula occludens 1 (ZO1), uma das moléculas responsáveis pela manutenção da proximidade das pedicelas podocitárias. Dessa forma, é possível que a própria malformação induzida pela administração neonatal de losartan afete estruturalmente os glomérulos, promovendo perda de podócitos ou alterações em sua função, que propiciam a passagem de macromoléculas pela barreira de filtração glomerular. A albuminúria desenvolvida neste modelo poderia ainda ser decorrente de processo de vicariância, isto é, o número reduzido de néfrons geraria um aumento adaptativo da filtração por néfron, que por sua vez causaria hipertensão e hipertrofia glomerular, levando então, de maneira secundária à perda de 
podócitos e conseqüente redução da seletividade da barreira de filtração. No entanto, tais explicações são necessariamente especulativas neste momento, uma vez que inexistem evidências experimentais em seu favor.

As análises histológicas mostraram que aos 210 dias de vida, os animais $L_{\text {Lact }}$ apresentaram elevado índice de esclerose glomerular nos. Esse índice aumentou progressivamente com 0 avançar da idade, agravando-se ainda mais aos 300 dias de vida. São vários os mecanismos que podem ter levado ao desenvolvimento de glomerulosclerose nesse modelo. O aparecimento de hipertensão e hipertrofia glomerulares em decorrência de uma adaptação ao reduzido número de néfrons pode representar um deles, já que esses fenômenos levam à produção de diversas citocinas e mediadores inflamatórios, em especial a All, resultando no recrutamento e proliferação de células inflamatórias. Além disso, a própria malformação glomerular característica do modelo pode ser um fator determinante para o aparecimento de glomeruloesclerose [14]. O fato de que esta se faz presente logo aos 60 dias de vida [24] é compatível com essa hipótese, embora não se possa excluir a instalação de mecanismos adaptativos já nessa fase.

Em consistência com esses achados, os animais submetidos ao bloqueio do receptor AT1 durante a nefrogênese apresentaram retenção de creatinina aos 300 dias, quando a concentração sérica desse metabólito alcançou níveis quase duas vezes superiores ao controle, refletindo uma acentuada queda do RFG e perda progressiva de função renal, comparável à observada em pacientes acometidos por DRC em fase 4 (pré-dialíticos). 
Trata-se, portanto de um modelo experimental bastante agressivo, apesar do desenvolvimento tardio da hipertensão. No entanto, dentre todas as alterações morfológicas características do modelo $L_{\text {Lact, }}$ o comprometimento do compartimento tubulointersticial chama a atenção.

Ao analisarmos a percentagem de superfície cortical renal ocupada por interstício notamos, já aos 210 dias de vida, que os animais cujas mães receberam losartan durante a lactação exibiram expansão intersticial significativamente superior àquela observada nos controles normais de mesma idade. Essa percentagem aumentou com a progressão da nefropatia, tornando-se ainda mais substancial aos 300 dias de vida. $\mathrm{O}$ aumento da área intersticial foi acompanhado por hipertrofia tubular, com aumento da área ocupada pela luz tubular e redução do número de perfis tubulares por $\mathrm{mm}^{2}$, uma vez que estes passam a ficar mais afastados uns dos outros. Em concordância com o observado em outros modelos experimentais [39, 64, 65], a expansão intersticial associou-se a vários fenômenos de natureza nitidamente inflamatória como elevada densidade de macrófagos e linfócitos no interstício renal, além de um aumento substancial no número de células intersticiais positivas para All.

Assim como a infiltração leucocitária, a proliferação de células tubulointersticiais também se mostrou elevada nos animais $L_{\text {Lact }}$ aos 210 dias de vida. A proliferação de células intersticiais e tubulares progrediu com o passar dos meses, atingindo valores particularmente elevados aos 300 dias de vida, caracterizando um processo inflamatório ativo. Da mesma forma, vastas áreas tubulointersticiais ocupadas por $\alpha$-actina de músculo liso, um 
forte indicativo da presença de miofibroblastos, foram detectadas precocemente nos animais $L_{\text {Lact. }}$ Essas áreas aumentaram em número e extensão com o avançar da nefropatia. Tanto a percentagem de área intersticial ocupada por $\alpha$-actina de músculo liso como a taxa de proliferação celular estabeleceram uma correlação positiva com a expansão intersticial.

O surgimento de miofibroblastos no interstício renal, sejam estes frutos de alterações fenotípicas dos próprios fibroblastos residentes, sejam produto da transdiferenciação de células epiteliais tubulares, é um indício bastante robusto do estabelecimento da cascata de eventos imunológicos que consagra a inflamação crônica, culminando com a fibrose renal e perda da função renal. Os miofibroblastos são células fisiologicamente envolvidas na maturação e retração da cicatriz; sendo, portanto especializadas na síntese de proteínas componentes da MEC, além de citocinas e outros mediadores inflamatórios. Tais células manifestam algumas semelhanças funcionais com as células musculares, tais como a contratilidade, conferida pela presença abundante de proteínas específicas como a $\alpha$-actina de músculo liso. Desta forma podemos empregar essa proteína como um bom marcador para a presença de miofibroblastos intersticiais [57]. Em situação fisiológica, a expressão da $\alpha$-actina no tecido renal restringe-se aos vasos sanguíneos, em especial artérias e arteríolas, ricas em musculatura lisa. Já nos tecidos acometidos por inflamação avançada, a presença dessa proteína no compartimento intersticial indica a presença de miofibroblastos nessa região, compatível com um quadro de fibrose crônica. 
Como demonstrado nos resultados a área intersticial ocupada por $\alpha$ actina mostrou-se numericamente aumentada em relação ao controle já aos 210 dias de vida. Aos 300 dias, pudemos verificar um aumento significativo desse parâmetro em relação ao controle, em concordância com o desenvolvimento de fibrose observado nesses animais. Esses dados corroboram resultados obtidos previamente, neste e em outros laboratórios, [18-27], que caracterizaram as anormalidades observadas no parênquima renal dos animais submetidos ao bloqueio do SRAA neonatal, evidentes já aos 2 meses de vida [27], como predominantemente intersticiais.

As possíveis causas para essa expansão intersticial não estão claramente definidas. Alguns dos efeitos teratogênicos de losartan sobre a nefrogênese incluem malformações da vasculatura renal, redução da ramificação dos vasos e formação de um número reduzido de glomérulos, com conseqüente atrofia de estruturas tubulares, o que pode estimular a proliferação de miofibroblastos e a deposição precoce de MEC. Dados recentes da literatura apontam para uma relação positiva entre a rarefação e/ou malformação da vasculatura renal e o desenvolvimento de fibrose intersticial [71-74]. Uma vez que o parênquima renal é um sítio fisiológico de alto consumo de oxigênio, uma situação de hipoperfusão ocasionada pela escassez de vasculatura decorrente do bloqueio neonatal do SRAA poderia conduzir o órgão a uma situação de hipóxia, contribuindo para o processo de fibrogênese.

O parênquima renal é descrito como uma estrutura propícia para o desenvolvimento de hipóxia. Mesmo em situação fisiológica, a medula renal 
encontra-se exposta a uma pressão parcial de oxigênio inferior àquela observada no córtex. A razão para esse fenômeno é dupla: de um lado, a própria arquitetura dos vasos retos que acompanham as alças de Henle dos néfrons longos estabelece um mecanismo de contracorrente que dificulta a chegada do oxigênio às porções mais internas da medula; de outro, a intensa atividade das bombas transportadoras dependentes de ATP nessa região força a um alto consumo de oxigênio [75]. Crescem evidências de que a hipóxia pode atuar como um estímulo pró-inflamatório, desencadeando a atividade de inúmeros fatores de transcrição, como o HIF-1 (fator 1 indizível por hipóxia), responsável pela ativação de mais de 70 genes relacionados com proliferação celular, síntese de MEC, angiogênese e eritropoiese. Nangaku et al demonstraram recentemente que em situações de inflamação crônica, nas quais observa-se estresse oxidativo, parte do oxigênio que atinge as porções mais profundas da medula renal é desviada para a produção de espécies reativas de oxigênio, reduzindo o aporte desse gás às células tubulares $[77,78]$.

Os animais submetidos ao bloqueio do SRAA durante a lactação apresentavam redução apenas numérica na quantidade de capilares peritubulares por $\mathrm{mm}^{2}$ em relação aos animais controle. Não foi observada rarefação capilar quando se procedeu a contagem do número de capilares peritubulares por perfil tubular no parênquima dos animais $L_{\text {Lact. }}$

É importante salientar que o fato de a relação capilar peritubular / túbulo renal não estar alterada não exclui por si só a possibilidade de uma menor entrega de oxigênio no parênquima renal desses animais, uma vez 
que, como foi mostrado, a área entre um túbulo e o outro, a ser perfundida por oxigênio está expandida nos animais $L_{\text {Lact, }}$ além de estar ocupada principalmente por matriz extracelular, de difícil perfusão. Os resultados das análises de correlação entre o número total de capilares peritubulares e a expansão intersticial no modelo $L_{\text {Lact }}$ mostraram que a rarefação capilar nesse modelo experimental parece ter sido conseqüência e não causa da exuberante fibrose renal observada nos animais $L_{\text {Lact }}$ aos 300 dias de vida. Ainda não existe um consenso sobre o verdadeiro papel da hipóxia na patogênese da DRC. É possível que esta seja, na maioria dos casos, simplesmente uma conseqüência do acúmulo de colágeno no compartimento intersticial [76]. Por outro lado, a hipóxia pode ser um fator crucial para o início do processo de fibrose. É interessante elucubrar aqui a possibilidade da participação dos mecanismos de hipóxia no desenvolvimento da DRC neste modelo experimental, uma vez que, como já foi mencionada, a rarefação da vasculatura renal é uma das conseqüências da administração de losartan durante a nefrogênese, no entanto, não foram encontrados indícios de que um processo de rarefação capilar tenha sido o principal causador da lesão tubulointersticial apresentada pelos animais $L_{\text {Lact. }}$.

Outro ponto a ser levado em consideração como provável causador da grave lesão intersticial observada nesse modelo é a própria All. Como já foi discutido, a All participa ativamente do processo de remodelamento tecidual vigente durante a nefrogênese, agindo como mediador inflamatório e promovendo tanto a proliferação celular como a apoptose seletiva, desempenhando também um papel destacado na correta orientação e 
posicionamento das novas células formadas, à medida que medeia as interações célula-célula, bem como a adesão intercelular [68]. É possível que o bloqueio neonatal do SRAA ocasione um desequilíbrio entre proliferação e morte celulares, gerando uma hipercelularidade precoce no parênquima renal, que por alguma razão se perpetua. Além disso, durante a nefrogênese, a All regula positivamente, a atividade das metaloproteinases, responsáveis pela degradação e renovação da MEC, através da inibição dos TIMPs (Tissue inhibitor of metalloproteinases). Dessa maneira uma possível redução da síntese ou da atividade dessas enzimas poderia contribuir para o acúmulo de MEC nessa fase.

$O$ antagonismo entre produção e degradação da MEC, sem que qualquer dos dois predomine, mantém-se durante toda a vida. Discute-se hoje se a instalação de um quadro de fibrose, nos rins ou em qualquer outro órgão, reflete uma ruptura desse equilíbrio, devido a um excesso de produção de MEC, a uma deficiência em sua degradação, ou a uma combinação dessas duas anomalias. Os resultados obtidos no presente estudo com a técnica de zimografia sugerem que o acúmulo precoce de MEC no interstício renal não resulta de uma proteólise deficiente, uma vez que tanto a MMP2 como a MMP9 exibiram maior atividade nos grupos com expansão intersticial mais intensa. Esses achados indicam que a resposta dessas enzimas ao aumento da disponibilidade de substrato foi adequada, e que a atividade aumentada das gelatinases nos animais que receberam $L$ neonatal é conseqüência, e não causa, da expansão da MEC. 


\section{RESPOSTA AOS TRATAMENTOS}

Trata-se do primeiro estudo a examinar o efeito do tratamento farmacológico da nefropatia progressiva ocasionada pelo bloqueio do receptor AT1 durante a nefrogênese, com vistas a prevenir a progressão das lesões características desse modelo experimental.

\section{LOSARTAN}

Paradoxalmente, o losartan, a mesma droga responsável por causar a lesão renal quando administrada no período do desenvolvimento renal, limitou a progressão da esclerose glomerular, impediu o desenvolvimento de hipertensão e preveniu a progressão da albuminúria quando administrada a esses mesmos animais na vida adulta; atuando no modelo $L_{\text {Lact }}$ de maneira semelhante ao observado em outros modelos experimentais.

As propriedades anti-hipertensivas dos BRAT1 são há muito tempo conhecidas, e devem-se ao bloqueio dos efeitos biológicos da All, tais como: vasoconstrição, aumento da reabsorção de sódio, aumento da secreção do hormônio anti-diurético, ativação simpática e produção de aldosterona. Além desses fatores, diferentes estudos publicados recentemente têm discutido o papel dos antagonistas do receptor AT1 da All no controle do processo inflamatório associado à progressão da DRC, uma vez que a All exerce também um relevante papel como mediador inflamatório e fator estimulante da proliferação celular [8].

Os mecanismos específicos através dos quais o tratamento com losartan impediu o aparecimento de hipertensão nos animais do grupo 
$L_{\text {Lact }}+\mathrm{L}$ ainda não puderam ser totalmente determinados. Com base nos resultados obtidos, podemos observar que as lesões histológicas como GS e expansão intersticial parecem ter se desenvolvido anteriormente ao surgimento da hipertensão arterial neste modelo experimental; fato que sugere que a ação anti-hipertensiva conferida pelo tratamento com losartan decorreu de um efeito renoprotetor e antiinflamatório da droga, que reduziu o desenvolvimento de lesões histológicas (glomerulares e intersticiais) e, em vista do discutido acima, impediu o desenvolvimento da hipertensão.

Como demonstrado em outros estudos, o modelo L Lact $_{\text {caracteriza-se }}$ por hipertensão glomerular precoce [27] e a prevenção da progressão desta com a administração de losartan pode ter sido um dos mecanismos que levou a redução da glomerulosclerose, bem como da albuminúria nos animais do grupo $\mathrm{L}_{\mathrm{Lact}}+\mathrm{L}$. Tal achado se deve provavelmente ao conjunto dos conhecidos efeitos renoprotetores de losartan, que incluem vasodilatação eferente, aumento da excreção renal de sódio, redução da pressão arterial sistêmica e da pressão dos capilares glomerulares e contenção do processo inflamatório intraglomerular. De maneira semelhante, o efeito renoprotetor de losartan sobre a albuminúria pode ser atribuído também tanto à ação hemodinâmica da droga quanto a sua ação antiinflamatória [8], uma vez que inibe a infiltração e proliferação de células inflamatórias no compartimento glomerular. Estudos recentes indicam ainda que o tratamento com inibidores do SRAA pode restaurar a estrutura e a capacidade de proliferação dos podócitos, promovendo repovoamento da barreira de filtração $[69,70]$. 
Contrastando com os resultados obtidos com outros modelos experimentais, especialmente o modelo de ablação renal de 5/6, o tratamento com losartan na vida adulta não foi eficaz em prevenir a progressão da expansão e inflamação intersticial, sugerindo que as propriedades antiinflamatórias de losartan não fizeram frente à gravidade da lesão tubulointersticial do modelo $L_{\text {Lact }}$ nessa fase avançada. Por outro lado, a monoterapia com losartan preveniu o aumento das áreas intersticiais ocupadas por a-actina de músculo liso, bem como da proliferação tubulointersticial observadas nos animais $L_{\text {Lact }}$ aos 300 dias de vida.

Os animais $L_{\text {Lact }}$ tratados com losartan na vida adulta apresentaram hipercalemia, provavelmente ocasionada em parte pela própria insuficiência renal e em parte pelo bloqueio do receptor AT1, possivelmente através de uma redução da síntese de aldosterona. Esse resultado difere do obtido no modelo NX, no qual a administração de BRAT1 não chega a elevar de modo sensível os níveis de potássio sérico, mesmo em doses extremamente elevadas [46].

\section{HIDROCLOROTIAZIDA}

Contradizendo o conceito de que os tiazídicos são ineficazes na DRC avançada, a monoterapia com hidroclorotiazida preveniu o desenvolvimento de hipertensão e limitou a progressão da albuminúria nos animais $L_{\text {Lact }}+H$. Assim como outros diuréticos tiazídicos, a hidroclorotiazida inibe a ação dos co-transportadores neutros, que promovem a reabsorção de um íon sódio $\left(\mathrm{Na}^{+}\right)$e um íon cloreto $\left(\mathrm{Cl}^{-}\right)$através da membrana apical das células do túbulo distal; reduzindo a reabsorção de sódio neste segmento e impedindo, 
graças ao efeito natriurético resultante, o desenvolvimento de hipertensão arterial.

ASSOCIAÇÃO DE LOSARTAN (L) + HIDROCLOROTIAZIDA (H)

Dentre todos os tratamentos empregados, a associação de $\mathrm{L}+\mathrm{H}$ foi aquele que apresentou o efeito anti-hipertensivo mais eficaz: não só impediu o desenvolvimento de hipertensão arterial, como também trouxe os valores de pressão caudal a níveis inferiores àqueles observados no próprio grupo controle. Tal efeito foi provavelmente alcançado devido à soma das diferentes ações anti-hipertensivas dos referidos fármacos: enquanto o losartan apresenta efeito antiinflamatório e vasodilatador, além de limitar a reabsorção proximal de sódio, a hidroclorotiazida inibe a reabsorção de sódio no túbulo distal, complementando assim a ação do bloqueio do receptor AT1. De modo semelhante, os valores de albuminúria observados nos animais tratados com a associação $\mathrm{L}+\mathrm{H}$ foram estatisticamente inferiores não só àqueles observados no grupo $L_{\text {Lact }}+V$, como também àqueles apresentados pelo grupo pré-tratamento ( $\left.L_{\text {Lact }}+P r e ́\right)$, indicando a regressão desse parâmetro. É interessante notar que a albuminúria dos animais tratados com a associação das drogas não foi estatisticamente diferente daquela encontrada no próprio grupo controle. A associação terapêutica $\mathrm{L}+\mathrm{H}$ exibiu ainda um efeito renoprotetor superior à monoterapia com losartan no que diz respeito ao controle da concentração sérica de creatinina, da proliferação excessiva das células intersticiais e do aumento da área tubulointersticial ocupada por a-actina de músculo liso. Esses 
resultados sugerem a existência de um efeito sinérgico obtido com a associação dos fármacos administrados.

A associação de $\mathrm{L}+\mathrm{H}$ impediu a progressão da glomerulosclerose no modelo L Lact. No entanto, apesar do provável sinergismo entre as drogas, os índices de esclerose glomerular apresentados pelos animais tratados com $\mathrm{L}+\mathrm{H}$ não diferiram significativamente daqueles observados no grupo tratado exclusivamente com losartan. Esses resultados diferem dos observados anteriormente neste laboratório com o modelo de ablação renal de 5/6 [43], no qual a associação de hidroclorotiazida aumentou substancialmente a eficácia do tratamento com losartan. Da mesma forma, a associação de hidroclorotiazida ao tratamento com losartan não promoveu renoproteção adicional no que diz respeito à expansão intersticial, à infiltração macrofágica e linfocitária e à presença de células intersticiais positivas para All.

Não há uma explicação imediata para essa discrepância entre este modelo experimental e o de ablação renal de $5 / 6$. Assumindo que os animais que receberam losartan durante a nefrogênese comportam-se como perdedores de sal na vida adulta, o impacto da associação de um diurético ao bloqueio do SRAA pode ter sido limitado, ao contrário do que ocorre no modelo NX, no qual existe uma tendência à expansão do compartimento extracelular. Além disso, é possível que os fatores hemodinâmicos que atuam no modelo NX sejam menos importantes no modelo $L_{\text {Lact, }}$, no qual a lesão glomerular pode depender de fatores intrínsecos, relacionados à própria malformação renal, que desencadeia um processo inflamatório e proliferativo auto-sustentado. No entanto, é preciso salientar que, na 
ausência de evidências concretas, tais explicações permanecem no terreno das conjecturas.

O grau já muito avançado da DRC no momento de início dos tratamentos pode ter contribuído para o desempenho insatisfatório tanto da monoterapia com losartan como da associação $L+H$, uma vez que, já aos 210 dias de vida, a inflamação/fibrose intersticial era bastante pronunciada. Esses achados indicam que o modelo de tratamento neonatal com BRAT1 pode simular com mais fidelidade a observação clínica de que pacientes com DRC avançada apresentam-se freqüentemente resistentes aos tratamentos que visam conter sua progressão.

Por fim, a associação de hidroclorotiazida ao tratamento com losartan impediu o desenvolvimento de hipercalemia, uma vez que a ação do tiazídico, no tocante à excreção de potássio, contrapõe-se à dos BRAT1. Provavelmente, a ação do diurético sobre as células tubulares promoveu um aumento da perda urinária de potássio, contrabalançando os efeitos do losartan e, dessa forma, mantendo as concentrações plasmáticas desse íon em níveis normais. 


\section{CONCLUSÕES}

1- Perante o exposto, podemos concluir que os mecanismos inflamatórios, proliferativos e fibrogênicos parecem ter sido mais importantes para a progressão da nefropatia do modelo $L_{\text {Lact }}$ do que as alterações hemodinâmicas ou a redução no número de unidades filtradoras por si. A exuberante expansão intersticial observada nos animais L Lact $_{\text {não parece ter }}$ sido fruto de uma redução da síntese ou da atividade das metaloproteinases, uma vez que essas apresentaram sua atividade proteolítica aumentada nesse modelo experimental. De maneira semelhante, podemos atribuir à relativa rarefação dos capilares peritubulares presente no modelo L Lact uma relação de conseqüência e não de causa para com a fibrose intersticial, uma vez que o número de capilares peritubulares passa a estabelecer correlação com a expansão intersticial somente aos 300 dias de vida.

2- A associação de losartan e hidroclorotiazida preveniu o desenvolvimento de hipertensão, promoveu regressão completa da albuminúria, limitou o aumento da concentração de creatinina sérica, preveniu o aumento da área intersticiai ocupada por a-actina de músculo liso, bem como da proliferação celular intersticial. Por outro lado, a adição de hidroclorotiazida à terapia com losartan não promoveu renoproteção adicional no tocante a esclerose glomerular, expansão e inflamação intersticial. 
3- A renoproteção apenas parcial obtida pela administração da associação $\mathrm{L}+\mathrm{H}$ no modelo $\mathrm{L}_{\text {Lact }}$ contrastou com a exuberante renoproteção atingida com esse mesmo esquema terapêutico no modelo de ablação renal de 5/6. Provavelmente o caráter mais inflamatório e menos hemodinâmico da nefropatia do modelo $L_{\text {Lact, }}$ associado ao fato de que os animais tratados com losartan durante a lactação tornam-se "perdedores de sal" na vida adulta, respondendo de maneira menos pronta a ação dos diuréticos, contribuíram para essa discrepância entre os modelos experimentais. 


\section{REFERÊNCIAS}

1. ROMÃO JR J.E. Insuficiência Renal Crônica in Nefrologia. Jenner Cruz, José Nery Praxedes, Helga Maria Mazzarolo Cruz. Págs. 248265. $2^{a}$ edição. Editora Sarvier. São Paulo, 2006

2. ZATZ R, ROMÃO JE JR. End-stage renal failure and national resources: the Brazilian experience. Renal Failure 28(8):627-9; 2006

3. CORESH J, ASTOR BC, GREENE T, et al. Prevalence of chronic kidney disease and decreased kidney function in the adult US population: Third national Health and Nutrition Examination survey. Am J Kidney Dis; 41:1-12, 2003

4. LAMEIRE N, JAGER K, VAN BIESEN $W$ et al. Chronic Kidney disease: a European perspective. Kidney Int Suppl; 99:530-538; 2005

5. ZATZ $R$ in Fisiopatologia Renal. Ed. Silva, MR, ed Atheneu, $2^{a}$ edição, 2002.

6. ANDERSON S. Mechanisms of injury in progressive renal disease. Exp Nephrol Suppl 1:34-40; 1996.

7. HAYSLETT S. Functional adaptation to reduction in renal mass. Physiol Rev.59:137-164, 1979.

8. NORONHA IL, FUJIHARA CK, ZATZ R. The inflammatory component in progressive renal disease - are interventions possible? Nephrol Dial Transplant 17:363-368; 2002

9. ZATZ R, FUJIHARA CK. Mechanisms of progressive renal disease: role of angiotensin II, cyclooxygenase products and nitric oxide. J Hypertens Suppl. 2002 Jun;20(3):S37-44.

10. KAGAMI S, BORDER WA, MILLER DE, NOBLE NA. Angiotensin II stimulates extracellular matrix protein synthesis through induction of 
transforming grow factor-beta expression in rat glomerular mesangial cells. J Clin Invest 93:2431-2437, 1994.

11. FOGO AB, et al. Renal Fibrosis: not Just PAl-1 in the Sky. J Clin Invest 112:326-328, 2003

12.ITURBE BR, QUIROZ Y, NAVA M, BONET L, CHAVÉZ M, HERRERA-ACOSTA J, JOHNSON RJ, PONS HA. Reduction of renal immune cells infiltration results in blood pressure control in genetically hypertensive rats. Am J Physiol Renal Physiol 282:F191-F201, 2002

13. LOPEZ MLSS, GOMEZ RA. The role of angiotensin II in kidney embryogenesis and kidney abnormalities. Curr Opin Nephrol Hypertension 13(1): 117-122, 2004

14. CHEN Y, LASAITIENE D, SRIBERG T. The rennin-angiotensin system in kidney development. Acta Physiol 181:529-535, 2004.

15.TUFRO-MCREDDIE A, ROMANO LM, HARRIS JM, FERDER L, GOMEZ RA: Angiotensin II regulates nephrogenesis and renal vascular development. Am J Physiol JID - 0370511 269:F110-F115, 1995.

16.WOODS LL, RASCH R. Perinatal ANG II programs adult blood pressure, glomerular number, and renal function in rats. Am. J. Physiol. 275(5 Pt 2):R1593-9, 1998.

17.GURON G, ADAMS MA, SUNDELIN B, FRIBERG P. Neonatal angiotensin-converting enzyme inhibition in the rat induces persistent abnormalities in renal function and histology. Hypertension 29(1 Pt 1):91-97, 1997.

18. FRIBERG P, SUNDENLIN B, BOHMAN SO, BOBIK A, NILSSON H, WICKMAN A, GUSTAFSSON H, PETERSEN J, ADAMS MA. ReninAngiotensin System in Neonatal Rats: Induction of a Renal 
Abnormality in Response to ACE inhibition or Angiotensin II Antagonism. Kidney Int 45(2): 485-92, 1994.

19. GURON G. Renal haemodynamics and function in weanling rats treated with enalapril from birth. Clinical and Experimental Pharmacology and Physiology 32:865-870, 2005

20. LASAITIENE D, CHEN Y, GURON G, MARCUSSEN N, TARKOWSKI A, TELEMO E, FRIBERG P. Perturbed medullary tubulogenesis in neonatal rat exposed to rennin-angiotensin system inhibition. Nephrol. Dial. Transplant. 18:2534-2541, 2003.

21. CORREA FMA, VISWANATHAN M, CIUFFO GM, TSUTSUMI K, SAAVEDRA JM. Kidney angiotensin II receptors and converting enzyme in neonatal and adult Wistar-Kyoto and spontaneously hypertensive rats. Peptides 16:19-24, 1995.

22. LASAITIENE D, FRIBERG P, SUNDELIN B, CHEN Y. Neonatal RAS inhibition changes the phenotype of the developing thick ascending limb of Henle. Am J Physiol Renal Physiol 286: F1144F1153, 2004

23. SPENCE SG, ZACCHEI AG, LEE LL, BALDWIN CL, BERNA RA, MATTSON BA. Toxicokinetic analysis of losartan during gestation and lactation in the rat. Teratology. 1996 Apr;53(4):245-52.

24. DAIKHA-DAHMANE F, LEVY-BEFF E, JUGLE M LENCLENR. Fetal kidney maldevelopment in maternal use of angiotensin II type I receptor antagonist. Pediatr Nephrol (5):729-32, 2006

25. ALWAN S, POLIFKA JE, FRIEDMAN JM. Angiotensin II receptor antagonist treatment during pregnancy. Birth defects Res A Clin Mol Teratol (2):123-30, 2005

26. BARROS EP, TELES F, MALHEIROS DMAC, ZATZ R, FUJIHARA CK. Caracterization of a model of progressive nephropathy based on 
Losartan (L) treatment during lactation. J Am Soc Nephrol 16:183A, 2005.

27. MACHADO FG, POPPI EP, FANELLI C, MALHEIROS DM, ZATZ R, FUJIHARA CK. AT1 blockade during lactation as a modelo $f$ chronic nephropathy: mechanisms of renal injury. Am J Physiol Renal Physiol;294(6):F1345-53, 2008.

28. BRENNER, BM. Nephron adaptation to renal injury or ablation. Am J Physiol 249: F324-F337, 1985.

29. LEWIS EJ, HUNSICKER LG, BAIN RP, ROHDE RK. The collaborative group. The effect of angiotensin-converting enzime on diabetic nephropathy. N Engl J Med 329:1456-1462,1993.

30. BARNETT A. Preventing renal complications in type 2 diabetes: results of the diabetics exposed to telmisartan and enalapril trial. J Am Soc Nephrol 17(4):S132-S135, 2006.

31. KANAZAWA M, KAWAMURA T, LI L, SASAKI Y, MATSUMOTO K, KATAOKA K, ITO O, MINAMI N, SATO T, OOTAKA T, KOHZUKI M. Combination of exercise and enalapril enhances renoprotective and peripheral effects in rats with renal ablation. Am J Hypertens 19(1):8086, 2006.

32. GARCIA-ESTAN J, ORTIZ MC, O'VALLE F, ALCARAZ A, NAVARRO EG, VARGAS F, EVANGELISTA $S$, ATUCHA NM. Effects of angiotensin-converting-enzyme inhibitors in combination with diuretics on blood pressure and renal injury in nitric oxide-deficiency-induced hypertension in rats. Clin Sci (Lond) 110(2):227-233, 2006.

33. TAAL MW, CHERTOW GM, RENNKE HG, GURANI A, JIANG T, SHAHSAFAEI A, TROY JL, BRENNER M, MACKENZIE HS. Mechanisms underlying renoprotection during renin-angiotensin system blockade. Am J Physiol Renal Physiol 280:343-355,2001 
34. BRENNER BM, COOPER ME, de ZEEUW D et al. Effects of losartan on renal and cardiovascular outcomes in patients with type 2 diabetes and nephropathy. N Engl J Med 345:861-869, 2001.

35. LEWIS EJ, HUNSICKER LG, CLARKE WR et al. Renoprotective effect of the angiotensin receptor antagonist ibesartan in patients with nephropathy due to type 2 diabetes. N Engl J Med 345;851-860, 2001.

36. STOJILJKOVIC L, BEHNIA R. Role of renin angiotensin system inhibitors in cardiovascular and renal protection: a lesson from clinical trials. Curr Pharm Des 13(13):1335-1345, 2007

37. FUJIHARA CK, VELHO M, MALHEIROS DMAC, ZATZ R. An extremely high dose of losartan affords superior renoprotection in the remnant model. Kidney International 67:1913-1924, 2005.

38. TELES $F$, MACHADO FG, VENTURA BH, MALHEIROS DM, FUJIHARA CK, SILVA LF, ZATZ R. Regression of glomerular injury by losartan in experimental diabetic nephropathy. Kidney Int. 2008 Oct 22.

39. FUJIHARA CK, NORONHA IL, MALHEIROS DMAC, ANTUNES GR, de OLIVEIRA IB, ZATZ R. Combined mycofenolate mophetil and Losartan therapy arrests established injury in remnant kidney. J. Am. Soc Nephrol. 11 (2)283-90, 2000.

40. ANDERSON S, MEYER TW, RENNKE HG, BRENNER BM. Control of glomerular hypertension limits glomerular injury in rats with reduced renal mass. J Clin Invest 76:612-619, 1985.

41.BRENNER BM, GARCIA DL AND ANDERSON S: Glomeruli and blood pressure: Less of one, more of the others? Am J Hypertens 1:335-347, 1988. 
42. UZU T, HARADA T, NAMBA T, YAMAMOTO R, TAKAHARA K, YAMAUCHI A, KIMURA G. Thiazide diuretics enhance nocturnal blood pressure fall and reduce proteinuria in immunoglobulin $A$ nephropaty treated with angiotensin II modulators. J Hypertens 23:861-865, 2005.

43. ZHOU X, MATAVELLI LC, ONO H, FROHLICH ED. Superiority of combination of thiazide with angiotensin-converting enzyme inhibitor or AT1-receptor blocker over thiazide alone on renoprotection in LNAME/SHR. Am J Physiol Renal Physiol 289:F871-F879, 2005.

44. VOGT L, WAANDERS F, BOOMSMA F, de ZEEUW D, NAVIS G. Effects of dietary sodium and hydrochlorotiazide on the antiproteinuric efficacy of losartan. J Am Soc Nephrol 19(5):999-1007, 2008.

45. BAKRIS GL, TOTO RD, McCULLOUGH PA, ROCHA R, PURKAVASTHA D, DAVIS $P$. Effects of different ACE inhibitor combinations on albuminuria: results of the GUARD study. Kidney Int 19,2008

46. FUJIHARA CK, MALHEIROS DMAC, ZATZ R. LosartanHydrochlorothiazide association promotes lasting blood pressure normalization and completely arrest long termal injury in the 5/6 ablation model. Am J Physiol Renal Physiol, 2007 Mar 6; [Epub ahead of print]

47. KLIEM V, JOHNSON RJ, ALPERS CE, YOSHIMURA A, COUSER WG, KOCH KM, FLOEGE J. Mechanisms involved in the pathogenesis of tubulointerstitial fibrosis in 5/6-nephrectomized rats. Kidney Int 49:666-678, 1996.

48. JOHNSON RJ, ALPERS CE, YOSHIMURA A, LOMBARDI D, PRITZI P, FLOEGE J, SCHWARTZ SM. Renal injury, from, angiotensin IImediated hypertension. Hypertension 19:464-474, 1992. 
49. YANG N, WU LL, NIKOLIC-PATERSON DJ, NG YY, YANG WC, MU W, GILBERT RE, COOPER ME, ATKINS RC, LAN HY. Local macrophage and myofibroblast proliferation in progressive renal injury in the rat remnant kidney [In Process citation]. Nephrol Dial Transplant 13:1967-1974, 1998.

50. MULLER DN, DECHEND R, MERVAALA EMA, PARK JK, SCHMIDT F, FIEBELER A, THEUNERr J, BREU $V$, GANTEN D, HALLER H, LUFT F. NF-KB inhibition ameliorates angiotensina IIinduced inflammatory damage in rats. Hypertension 35:193-201, 2000.

51. FUJIHARA CK, MICHELLAZZO SM, DENUCCI G AND ZATZ R: Sodium excess aggravates hypertension and renal parenchymal injury in rats with chronic NO inhibition. Am J Physiol. 1994 May; 266(5 Pt2): F697-705

52. ZATZ R, DUNN BR, MEYER TW, ANDERSON S, RENNKE HG, BRENNER BM. Prevention of diabetic glomerulopathy by pharmacological amelioration of glomerular capillary hypertension. J Clin Ivest 77:1925-1930, 1986.

53. CHEN $Y$, LASAITIENE D, GABRIELSSON BG et al. Neonatal losartan treatment suppresses renal expression of molecles involved in cell-cell and cell-matrix interactions. J Am Soc Nephrol 15,12321243, 2004.

54. NAZARRO P, MANZARI M, MERLO M, TRIGGIANI R, SCARANO A, CIANCIO L, PIRRELLI A . Distinct and combined vascular effects of ACE blockade and HMG-CoA reductase inhibition in hypertensive subjects. Hypertension 33:719-25,1999.

55. LORIA A, REVERTE V, SALAZAR F, SAEZ F, LLINAS T, SALAZAR $\mathrm{J}$ : Changes in renal hemodynamics and excretory function induced 
by a reduction of Angll effects during renal development. Am J Physiol. 2007 May; 293: R695-700

56. MANCINI G, CARBONARA AO, HEREMANS JF: Immunochemical quantification of antigens by single radial immunodiffusion. Immunochemistry 2:235-254, 1965

57. JEPSEN FL, MORTENSEN PB. Interstitial fibrosis of the renal cortex in minimal change lesion and its correlation with renal function: a quantitative study. Virchows Arch A Pathol Anat Histol 383:265-70, 1979.

58.BRADFORD, MM. A rapid and sensitive for the quantitation of microgram quantitites of protein utilizing the principle of protein-dye binding. Analytical Biochemistry 72: 248-254. 1976.

59. WALLENSTEIN S, ZUCKER CL, FLEISS JL: Some statistical methods useful in circulations research. Circ Res 47:1-9, 1980.

60. A KHWAJA, M EL KOSSI, J FLOEGE, M EL NAHAS: The management of CKD: A look into the future. Kidney International, 72:1316-1323, 2007

61.LORI L WOODS AND RUTH RASCH: Perinatal ANG II programs adult blood pressure, glomerular number and function in rats. Kidney Int. 65(4):1339-48, 2004.

62. GUYTON A C, HALL J E in Fisiologia Humana e Mecanismos de Doenças. Ed. Guanabara Koogan, 6ª edição, 1998.

63. EDDY A A: Molecular basis of renal fibrosis. Pediatr. Nephrol. 15:290301, 2000.

64. GRACIANO L M, CAVAGLIERI R DE C, DELLE H, DOMINGUEZ W V, CASARINE D E, MALHEIROS DMAC, NORONHA IL: Intrarenal renin-angiotensin system is upregulated in experimental model of 
progressive renal disease induced by chronic inhibition of nitric oxide synthesis. J.Am.Soc.Nephrol 15:1805-1815, 2004.

65. FUJIHARA CK, ANTUNES GR, MATTAR AL, MALHEIROS DMAC, VIEIRA JM Jr, ZATZ R. Chronic Inhibition of nuclear factor-kappaB attenuates renal injury in the $5 / 6$ renal ablation model. Am J Physiol Renal Physiol 292(1): F29-9, 2006

66. VIEIRA JM Jr, RODRIGUES LT, MANTOVANI E, DELLÊ H, MATTAR AL, MALHEIROS DMAC, NORONHA IL, FUJIHARA CK, ZATZ R. Statin monotherapy attenuates renal injury in a salt-sensitive hypertension model of renal disease. Nephron Physiol 101(4): 82-91, 2005

67. DELLÊ H, ROCHA JRC, FANELLI C, MALHEIROS DMAC, VIEIRA JM Jr, NORONHA IL. Association of tamoxifen, an anti-fibrotic drug, with losartan and MMF promotes the most effective renal protection. $J$ Am Soc Nephrol 409a-409a, 2003.

68. LASAITIENE D, CHEN Y, ADAMS MA, FRIBERG P. Further insights into the role of angiotensin II in kidney development. Clin Physiol Funct Imaging 26:197-204, 2006

69. MACCONI D, SANGALLI $F$, BONOMELLI M, CONTI S, CONDORELLI L, GAGLIARDINI E, REMUZZI G, REMUZZI A. Podocyte Repopulation Contributes to Regression of Glomerular Injury by Ace Inhibition. The American Journal of Pathology 174, 2009

70. LIANG XB, MA LT, NAITO T, WANG Y, MADAIO M, ZENT R, POZZI A, FOGO AB. Angiotensin Type1 Receptor Blocker Restores Podocyte Potential to Promote Glomerular Endothelial Cell Growth. J Am Soc Nephron 17:1886-1895, 2006

71. GUNARATNAM L, BONVENTRE JV. Hif in Kidney Disease and Development. J Am Soc Nephron 20:1877-1887, 2009 
72. HAASE VH. Pathophysiological Consequences of HIF Activation. Ann. NY Acad. Sci. 1177:57-65, 2009

73. KANG DH, JOLY AH, OH SW, HUGO C, KERJASCHKI D, GORDON KL, MAZZALI M, JEFFERSON JA, HUGHES J, MADSEN KM, SCHREINER GF, JOHNSON RJ. Impaired Angiogenesis in the remnant kidney model: I. Potencial role of vascular endothelial growth factor and Thrombospondin-1. J Am Soc Nephrol 12: 1434-1447, 2001

74. KANG DH, HUGHES J, MAZZALI M, SCHREINER, JOHNSON RJ. Impaired Angiogenesis in the remnant kidney model: II. Vascular endothelial growth factor administration reduces renal fibrosis and stabilizes renal function. J Am Soc Nephrol 12: 1448-1457, 2001

75. HEYMAN SN, KHAMAISI M, ROSEN S, ROSENBERGER C. Renal Parenchymal Hypoxia, Hypoxia Response and the Progression of Chronic Kidney Disease. Am J Nephrol 28(6):998-1006, 2008

76. LUKS AM, JOHNSON RJ, SWENSON ER. Chronic Kidney Disease at High Altitude. J Am Soc Nephrol 19 2262-2271, 2008

77.PALM F, NANGAKU M, FASCHING A, TANAKA T, NORDQUIST L, HANSELL P, KAWAKAMI T, NISHIJIMA F, FUJITA T.Uremia induces abnormal oxygen consumption in tubules and aggravates chronic hypoxia of the kidney via oxidative stress. Am J Physiol Renal Physiol. 2010 Aug;299(2):F380-6.

78. MIMURA I, NANGAKU M. The suffocating kidney: tubulointerstitial hypoxia in end-stage renal disease. Nat Rev Nephrol. 2010 Nov;6(11):667-78.

79. Fujinaka $H$, Miyazaki $Y$, Matsusaka T, Yoshida $H$, Fogo AB, Inagami T, Ichikawa I. Salutary role of angiotensin in partial urinary tract obstruction. Kidney Int. 2000 Nov;58(5):2018-27 